KATIA DA SILVA WANDERLEY

\title{
PSICODIAGNÓSTICO: COMPREENSÃO DOS ASPECTOS PSÍQUICOS DA DOR EM PORTADORAS DE HÉRNIA DE DISCO
}

\author{
Tese apresentada ao Instituto \\ de Psicologia da Universidade \\ de São Paulo como parte dos \\ requisitos para obtenção do \\ título de Doutor em Psicologia.
}

São Paulo 
KATIA DA SILVA WANDERLEY

\section{PSICODIAGNÓSTICO: COMPREENSÃO DOS ASPECTOS PSÍQUICOS DA DOR EM PORTADORAS DE HÉRNIA DE DISCO}

Tese apresentada ao Instituto de Psicologia da Universidade de São Paulo como parte dos requisitos para obtenção do título de Doutor em Psicologia.

Área de concentração: Psicologia Clínica

Orientadora: Profa. Dra. Elisa Maria

Parahyba Campos

São Paulo 


\section{PSICODIAGNÓSTICO: COMPREENSÃO DOS ASPECTOS PSÍQUICOS DA DOR EM PORTADORAS DE HÉRNIA DE DISCO}

KATIA DA SILVA WANDERLEY

\section{BANCA EXAMINADORA}

(Nome e Assinatura)

(Nome e Assinatura)

(Nome e Assinatura)

(Nome e Assinatura)

(Nome e Assinatura)

Tese defendida e aprovada em: 
Dedico esta tese aos meus pais,

Jamiro, que me mostrou o caminho da honestidade e perseverança combinado com muita generosidade, tornando agradável e motivador o percurso para a conquista, e Georgina, luz especial que ilumina minha vida. 


\section{AGRADECIMENTOS}

À Professora Doutora Elisa Maria Parahyba Campos, minha orientadora, pela acolhida quando fiquei sem orientação, pela confiança no meu trabalho e principalmente pela segurança e incentivo com que sempre discutiu o desenvolvimento desta tese.

Aos Professores Doutores Maria Júlia Kovács e Avelino Luiz Rodrigues, pelas sugestões apresentadas por ocasião do exame de qualificação.

Ao Dr. Carol Sonenreich, diretor do Serviço de Psiquiatria e Psicologia Médica do Hospital do Servidor Público do Estado de São Paulo, e ao Dr. Giordano Estevão, chefe da seção de Psicologia. Primeiro, pela compreensão com que sempre receberam minhas solicitações, tornando possível o inicio, o desenvolvimento e o término desta tese. Segundo, pela determinação e ao mesmo tempo flexibilidade com que administram o serviço, possibilitando assim a coexistência de diferentes formas de se pensar a doença mental, o doente e sua família, garantindo assim a eficiência do trabalho realizado tanto no ambulatório quanto na enfermaria do Serviço de Psiquiatria e Psicologia Médica do HSPE.

Ao Dr. José Marcus Rotta, diretor da Neurocirurgia do Hospital do Servidor Público Estadual, pela confiança e incentivo ao trabalho realizado pela Psicologia.

Ao Dr. Ricardo Vieira Botelho, pelo encaminhamento dos pacientes à seção de Psicologia.

Às psicólogas Milene Shimabuko e Rita de Cássia Barreto Casoni de Paula Fernandes, pelo atendimento dos pacientes encaminhados pela Neurocirurgia.

À psicóloga e psicanalista Silvia Leonor Alonso, pela dedicação com que de modo excepcional acompanhou a leitura freudiana, permitindo o aprimoramento dos meus conhecimentos dentro dessa abordagem teórica, sendo ao mesmo tempo, o aconchego para a minha ansiedade e angústia diante de um campo do saber tão complexo. 
Ao Orlando Di Marco, por cuidar da minha dor.

À Maria Tereza Viscarri Montserrat, exemplo de perseverança no alcance dos objetivos; suavidade sempre muito presente, sinalizando o compasso delicado por onde se caminhar, mesmo quando a necessidade de imposição se fizera prioritária.

À Mariângela Bento, integração muito bem articulada de seriedade, disponibilidade e bom humor, habilidades que confortam e com as quais sempre pude contar.

À Bia pela atitude firme com que 'determinou’ a continuação deste trabalho, em um momento onde a sua realização se encontrava ameaçada de extinção.

À Vera Bonato, generosidade surpreendente, tranqüilidade e paciência incomparáveis com que me auxiliou na integração do método com o material clínico.

Ao Rafael Varela, pelo cuidado demonstrado no trabalho de revisão de Português, pela editoração do trabalho e, sobretudo, pela constante tranqüilidade com que sempre recebeu minhas ‘aflições’ no envio do material desta tese.

Ao Valdecir Senna Cavalcanti, Nádia Haeead Carvalho Cavalcanti e Lourival Garcia, pela atenção e dedicação na encadernação dos exemplares.

À Vera Lucia Moré Wanderley, exemplo de coragem para enfrentar as vicissitudes da vida, por me lembrar insistentemente que conquistar é sempre possível.

À Luciene Santos da Costa, que durante a minha ausência, substituiu-me no cuidado, carinho e dedicação à minha família.

À Carmen Silvia Nogueira, Santuza Cavalini e Silvia Regina de Andrade Telles, pela preocupação em me ajudarem e principalmente pelo apoio quando tudo parecia ficar difícil demais para continuar.

À Eliane Ribeiro Moreira de Moraes e Nidia Vailati Aribi, pelo empenho em me auxiliar nos detalhes finais desta tese.

Aos colegas do Hospital do Servidor Publico do Estado de São Paulo, pelo carinho com que sempre me receberam. 


\section{AUTOPSICOGRAFIA}

O poeta é um fingidor

Finge tão completamente

Que chega a fingir que é dor A dor que deveras sente.

E os que lêem o que escreve,

Na dor lida sentem bem,

Não as duas que ele teve Mas só a que eles não têm.

E assim nas calhas de roda Gira, a entreter a razão, Esse comboio de corda Que se chama coração.

FERNANDO PESSOA 


\section{SUMÁRIO}

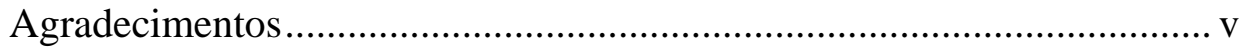

Listas de Figuras................................................................................ ix

Listas de Abreviaturas e Siglas ...............................................................

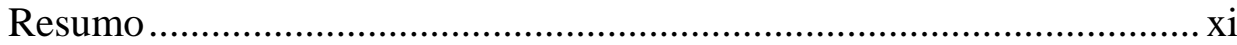

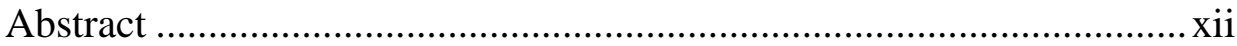

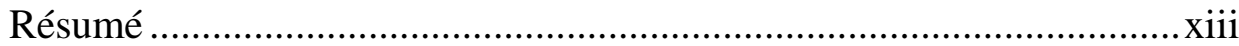

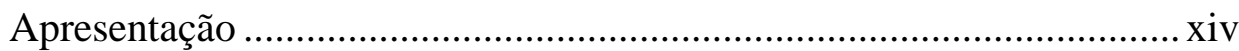

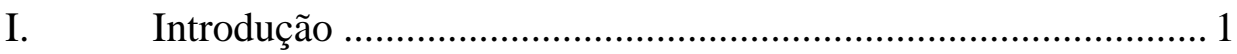

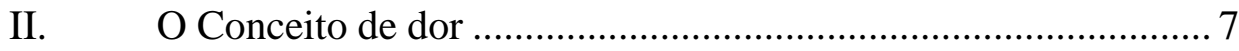

III. O Referencial Psicanalítico na Compreensão da dor ................. 14

a) A dor segundo a leitura de Freud .......................................... 14

IV. O Psicodiagnóstico .................................................................... 32

a) Caracterização do processo de Psicodiagnóstico ................... 32

b) As entrevistas no processo de Psicodiagnóstico .................... 35

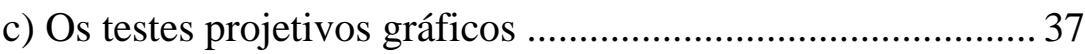

V. $\quad$ O Teste Projetivo Gráfico H.T.P. (House, Tree, Person).......... 42

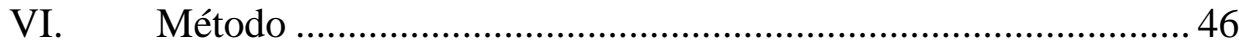

VII. Análise dos Resultados ........................................................... 52

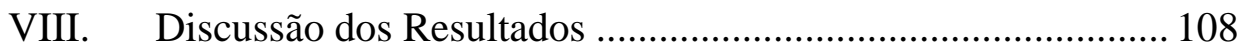

IX. Considerações Finais............................................................ 117

Referências Bibliográficas ............................................................. 121 


\section{LISTA DE FIGURAS}

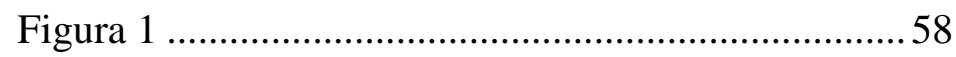

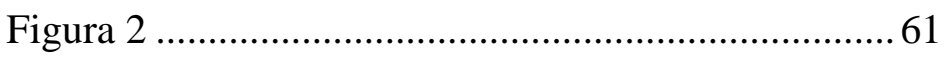

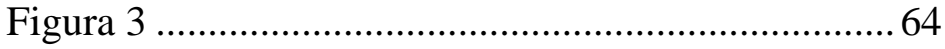

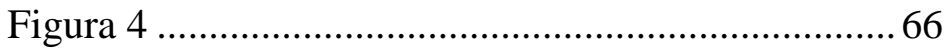

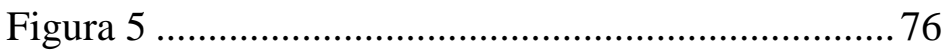

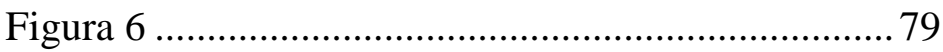

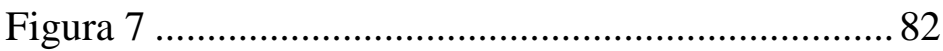

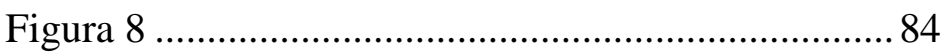

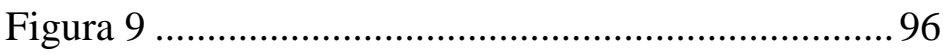

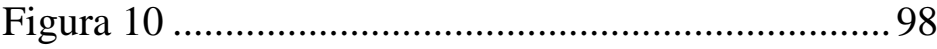

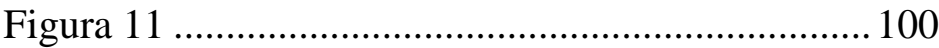

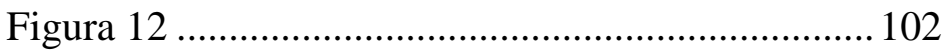




\section{LISTA DE ABREVIATURAS E SIGLAS}

$\begin{array}{ll}\text { HSPE } & \text { Hospital do Servidor Público Estadual } \\ \text { DSM } & \text { Diagnosis and Statical Manual of Mental Disorders } \\ \phi & \text { Phi } \\ \boldsymbol{\Psi} & \text { Psi } \\ \mathbf{\Omega} & \text { Omega } \\ \mathbf{Q} \text { e Qn(s) } & \text { Quantidade(s) } \\ \text { H.T.P. } & \text { House, Tree, Person } \\ \text { UNIP } & \text { Universidade Paulista } \\ \text { FMU } & \text { Faculdade Metropolitana Unidas } \\ \text { UniFMU } & \text { Centro Universitário das Faculdades Metropolitanas Unidas } \\ \text { FUNDAP } & \text { Fundação de Desenvolvimento Administrativo } \\ \text { AIDS } & \text { Síndrome de Imunodeficiência Adquirida }\end{array}$




\section{RESUMO}

WANDERLEY, Kátia da Silva. Psicodiagnóstico: Compreensão dos Aspectos Psíquicos da Dor em Portadoras de Hérnia de Disco. São Paulo, 2003. 143p. Tese (Doutorado). Instituto de Psicologia, Universidade de São Paulo.

Por meio do Psicodiagnóstico pretendemos estudar os aspectos psíquicos em pacientes com dor lombar devido à hérnia de disco. Os sujeitos são três pacientes, encaminhadas à seção de Psicologia do Hospital do Servidor Público Estadual (HSPE), pelo grupo de coluna da clínica de Neurocirurgia. Todas as pacientes foram submetidas ao exame clínico, a ressonância magnética e ao Psicodiagnóstico. O Psicodiagnóstico é composto por entrevistas e o teste projetivo H.T.P. (House, Tree, Person). Utilizaremos o referencial teórico psicanalítico para avaliar e analisar o material clínico obtido no Psicodiagnóstico. Os resultados visam possibilitar a compreensão da subjetividade da dor, evidenciando o sentido que o sintoma doloroso representa para esses sujeitos, e contribuir para o direcionamento da conduta terapêutica. 


\begin{abstract}
WANDERLEY, Kátia da Silva. Psychodiagnosis: Understanding the Psychics Aspects of the Pain in Patients with Disk Hernia. São Paulo, 2003. 143p. Thesis (Doctorate). Instituto de Psicologia, Universidade de São Paulo.
\end{abstract}

Through Psychodiagnosis we intend to study the psychics aspects regarding with lumbar pain due to a disk hernia. The subjects are three patients, sent to the Psychology Ward of the Hospital do Servidor Público Estadual (HSPE) by the group of doctors of the Neurosurgery Clinic. All patients go through a clinical test, magnetic resonance and Psychodiagnosis. Psychodiagnosis consists of interviews and the H.T.P. (House, Tree, Person) projective test. We will make use of the theoretical psychoanalitical references to evaluate and analyze the clinical material from the Psychodiagnosis. The results aim at making it possible to understand the subjectivity of pain showing what the painful symptom means to those subjects, and at contributing to the guidance of the therapeutical conduct. 


\section{RÉSUMÉ}

WANDERLEY, Katia da Silva. Diagnostic Psichologique: La Compréhension des Aspects Psychiques dela Douleur de Patients avec Hernie de Disque. São Paulo, 2003. 143p. Thèse (Doctorat). Instituto de Psicologia, Universidade de São Paulo.

Au moyen du diagnostic psychologique nous prétendons étudier les aspects psychiques de patients souffrant de douleurs lombaires par une hernie de disque. Les sujets sont trois patients Qui ont été acheminés au Département de Psychologie du Hospital do Servidor Público Estadual (HSPE) par le groupe de spécialistes de la colonne de la Clinique de Nerochirurgie. Tous les patients sont soumis à des examens cliniques, à la résonance magnétique et au diagnostic psychologique. Le diagnostic psychologique comprend des entretiens avec les patients ainsi que l' application du test projectif H.T.P. (House, Tree, Person). Nous utiliserons le référentiel théorique de la psychanalyse pour évaluer et analyser le matériel clinique contenu dans le diagnostic psychologique. Les résultats ont pour but de permettre la compréhension de la subjectivité de la douleur, en mettant em évidence le sens que le symptôme douloureux représente pour ces sujets, et dé contribuer à donner um meilleur fondement à la conduite thérapeutique. 


\section{APRESENTAÇÃO}

O ambulatório da seção de Psicologia do Serviço de Psiquiatria e Psicologia Médica do Hospital do Servidor Público Estadual (HSPE) atende pacientes encaminhados por todas as clínicas do complexo hospitalar Servidor Público do Estado de São Paulo. O Serviço de Psiquiatria desponta com o maior número de encaminhamentos à seção de Psicologia, seja para psicoterapia de crianças, adolescentes e adultos ou para a realização de Psicodiagnóstico.

Na maioria das vezes, os pedidos de avaliação psicológica solicitados pela Psiquiatria visam o encaminhamento mais pertinente à demanda do paciente, objetivando a sua inserção nos grupos de psicoterapia ou nas atividades do hospital dia. O hospital dia é uma internação psiquiátrica durante o dia, geralmente das 8 às 17 horas; pode ser diária ou em dias alternados, dependendo da patologia apresentada pelo paciente. No hospital dia, o paciente, além da medicação, participa de atividades como: grupo de socialização, de reflexão, de psicoterapia, participa também das reuniões junto aos profissionais do Serviço de Psiquiatria e Psicologia Médica, onde as discussões sobre a sua enfermidade mental, bem como o seu envolvimento com as atividades multidisciplinares do hospital dia, contribuem de modo significativo na sua recuperação.

Outro motivo de solicitação de Psicodiagnóstico pela clínica psiquiátrica é o auxílio no diagnóstico diferencial, geralmente entre deficiência mental e psicose, entre um quadro de neurose e psicose, para avaliar os recursos intelectuais bem como verificar provável deterioração mental em pacientes dependentes químicos ou portadores de doenças degenerativas.

Além das atividades no ambulatório, a seção de Psicologia atende aos pedidos de interconsulta de todas as clínicas do Hospital do Servidor Público do Estado de São Paulo. Geralmente os pedidos de interconsulta também se relacionam à avaliação psicológica, visando o esclarecimento à equipe multiprofissional sobre as 
condições psicológicas do paciente frente: 1 . ao esclarecimento do diagnóstico da enfermidade; 2. ao longo período de internação; 3. às condutas terapêuticas consideradas invasivas, como, por exemplo, amputações; e 4. aos exames que despertam ansiedade e angústia como, por exemplo, uma biopsia.

O grupo de coluna da Neurocirurgia do Hospital do Servidor Público Estadual do Estado de São Paulo atende pacientes que se queixam de fortes dores na coluna devido à hérnia de disco. Apesar, desses pacientes serem submetidos aos tratamentos convencionais medicamentosos e até mesmo cirúrgicos, os médicos vêm constatando que o sintoma doloroso não melhora.

A hérnia de disco acontece quando parte do núcleo polposo, disco gelatinoso, que fica entre as vértebras da coluna, se desloca e comprime a raiz nervosa, produzindo sintomas como formigamento e dor. A compressão e, conseguinte inflamação, das raízes nervosas é responsável pela dor ao longo da perna, conhecida pelo nome de ciática.

O passo inicial do tratamento para a hérnia de disco consiste no repouso, visando a redução da inflamação dos nervos. Sendo a hérnia de disco um problema anatômico, com compressão neurológica, que causa sintomas fisiológicos como dor e diminuição de força muscular, a primeira consideração a se tomar depois do repouso, é retirar o agente causador da compressão, que pode ser uma deficiência de postura, ou mesmo, ocupacional.

Vários exames estão disponíveis atualmente, como a ressonância magnética, que mostra o valor da perda da estrutura do disco e o nível de compressão do nervo. O Raio X também pode mostrar a posição das vértebras e irregularidades (www.abieducation.net).

Todavia, Amaral (2001, p.250) salienta que apesar da ressonância magnética permitir “aquisições de imagens com alto nível de resolução, muitas vezes são supervalorizados ou, ainda sobrepostos a um quadro clínico que não justifica a intervenção cirúrgica”.

Hakelius (1970, citado por Amaral 2001, p.250) “demonstrou, em seu trabalho sobre a evolução de pacientes operados e não operados de hérnia de disco, que dentre os doentes não operados e tratados conservadoramente com colete e repouso, 38\% melhoraram em um mês; 52\% em dois meses e 73\% em três meses”. 
Saal (1989, citado por Amaral 2001, p.250) "realizou um estudo retrospectivo em 58 doentes com radiculopatia por hérnia de disco, dos quais 52 foram submetidos a tratamento conservador, encontrando melhora em $90 \%$ dos casos e, apenas, três de 15 precisaram de tratamento cirúrgico”

A grande incidência de cirurgias de coluna devido à hérnia de disco chamou não só a atenção dos neurocirurgiões, como também da Diretoria do Hospital do Servidor Público do Estado de São Paulo, despertando a necessidade de conduta mais criteriosa principalmente na indicação da cirurgia, uma vez que nem sempre os procedimentos técnicos utilizados para o tratamento de dor lombar devido à hérnia de disco estariam sendo eficazes na remissão da dor.

O elevado número de cirurgias de coluna, seguido da manutenção do processo álgico, levaram os neurocirurgiões a pedirem interconsulta à seção de Psicologia, no final do ano 2000.

O encaminhamento para a seção de Psicologia evidencia que os neurocirurgiões se sensibilizaram para a influência dos fatores psíquicos como um dos motivos tanto para a permanência da dor após a cirurgia quanto para a solicitação intensa de alguns pacientes, que, mesmo sendo orientados a fazer os procedimentos pré-cirúrgicos, o que garantiria melhora significativa da dor, preferem a intervenção cirúrgica, desconsiderando completamente a possibilidade de resposta satisfatória para o processo álgico mediante outros procedimentos que não a cirurgia.

A partir desse pedido, seguiram-se algumas reuniões com neurologistas e psicólogos, quando se discutiu a importância de se conhecer melhor as características de personalidade desses pacientes, uma vez que, até então, nada havia sido feito nesse sentido.

Trabalho há 21 anos no ambulatório de Psicologia e venho constatando a importância do Psicodiagnóstico no esclarecimento dos traços estruturais e dinâmicos da personalidade o que facilita o direcionamento do tratamento ao paciente. Assim sendo, a proposta de utilizar essa técnica para melhor compreender os aspectos psíquicos desses pacientes me pareceu muito útil no auxílio a questão problema, trazida tanto pela Neurocirurgia quanto pela diretoria do Hospital do Servidor Público do Estado de São Paulo.

A maior parte das cirurgias de hérnia de disco acontece em pacientes que se queixam de muita dor, apesar de estarem sendo submetidos aos procedimentos 
técnicos disponíveis na clínica da Neurocirurgia. Devido à dor, os pacientes insistem para que a cirurgia feita, porém na opinião dos neurocirurgiões, em alguns pacientes o tamanho da hérnia detectado na ressonância magnética não justificaria o processo álgico intenso como o descrito pelo paciente. Nesses casos, esperar-se-ia remissão do quadro doloroso com tratamentos pré-cirúrgicos já mencionados. No entanto, em função das contínuas queixas de dor esses pacientes são submetidos à cirurgia, porém quando retornam ao ambulatório da neurocirurgia novamente mencionam sentir dor, apesar de alguns referirem uma certa melhora no processo doloroso.

A seção de Psicologia do Hospital do Servidor Público Estadual propôs à clínica da Neurocirurgia a realização do Psicodiagnóstico, tendo como objetivo detectar e analisar os fatores psíquicos que poderiam estar interferindo na sintomatologia da dor.

Estabeleceu-se que os neurocirurgiões encaminhariam à seção de Psicologia os pacientes que já haviam se submetido à cirurgia de hérnia de disco e continuavam com dor, bem como os pacientes que também apresentavam dor lombar e insistiam para fazer a cirurgia, apesar de não estarem fazendo uso de medicação e fisioterapia, para a realização do Psicodiagnóstico.

Assim sendo, esta tese se originou do pedido de interconsulta da clínica da Neurocirurgia do Hospital do Servidor Público Estadual corroborado pela solicitação da Diretoria desse hospital e pelo meu interesse em entender, esmiuçadamente, as características de personalidade dos pacientes portadores de hérnia de disco, que mesmo submetidos aos tratamentos disponíveis na clínica da Neurocirurgia continuam sentindo dor lombar.

A pesquisa qualitativa foi o delineamento escolhido para a realização deste estudo. Segundo Berthoud (2000, p.105):

Pensar qualitativamente é prescindir de números e da necessidade de generalizações e, em vez disso, usar as palavras e suas representações, buscar a consistência, a aplicabilidade e a transferibilidade dos resultados obtidos. É preocupar-se com o conteúdo e o contexto, com as subjetividades de pesquisador e pesquisado e acima de tudo, ousar.

Por se tratar de uma pesquisa que investigou os aspectos subjetivos de suas vivências, a metodologia qualitativa foi a mais adequada para compreendermos os aspectos psíquicos da dor em portadoras de hérnia de disco. 


\section{Introdução}

Geralmente, quando o paciente procura um profissional porque sente dor costuma explicar como é a sua dor. Alguns descrevem em detalhes toda a trajetória da sua dor, por exemplo: inicia na perna chegando até o quadril e finalmente na coluna, outros falam de uma dor que lateja, outros explicam que a dor é mais intensa em determinado momento do dia, e assim por diante.

A maneira como o paciente descreve o seu sofrimento revela seu jeito de ser, evidencia traços de sua personalidade e informa sobre a sua historia de vida, evidenciando, assim, que a dor é uma experiência subjetiva.

Assim sendo, as avaliações: psicológica, psiquiátrica, psicanalítica e socioeconômica constituem partes essenciais da pesquisa clínica de pacientes com dor crônica, na medida em que possibilitam a compreensão da sua subjetividade, facilitando a formulação do melhor planejamento terapêutico aos pacientes.

A qualidade da avaliação e a precisão do diagnóstico além de evitar condutas que poderiam ser invasivas e agressivas ao paciente constituem elementos importantes para os progressos na reabilitação, na medida em que ajudam a identificar componentes psíquicos que comprometem ou contribuem para a inserção dos pacientes em programas específicos de tratamento.

A presença de um psicólogo na equipe que pretende estudar a dor crônica traz a possibilidade de entendimento da subjetividade da dor. $\mathrm{O}$ alcance dessa compreensão só é possível graças à análise profunda do discurso do paciente, terreno de domínio da Psicologia e da Psiquiatria. No entanto, os meandros da subjetividade da dor nos lançam num campo onde nem sempre é possível enxergarmos com clareza o que tanto se procura.

Há necessidade de muita dedicação, empenho, disciplina e, sobretudo, paciência na busca do saber científico relacionado à dor crônica. A ênfase no atributo paciência não é à-toa, pois na prática da clínica psicológica nos deparamos com o 
ritmo de cada um para a constatação, reflexão e aceitação de algum fator mental relacionado a dor, pois só a partir dessa trajetória a mobilização para a mudança poderá ocorrer.

Quando mencionamos análise profunda da fala do paciente, inevitavelmente pensamos na Psicanálise. Sem dúvida, há outras abordagens que também se interessam pela compreensão da dor pelo discurso do paciente. Porém, como a decodificação do inconsciente é da competência exclusiva da Psicanálise a ela fica garantida a condição de aprofundar a análise que se propõe fazer sobre o objeto de estudo.

A doença física é diagnosticada pelo exame físico, exames de laboratório, Raios X, ultra-som, ressonância magnética etc. Os males da mente são diagnosticados pelo exame das palavras.

Freud, em Tratamento Psíquico (ou mental) (1905/1969), atribui às palavras papel indispensável e único no tratamento mental. Segundo Freud (1905, p.306):

As palavras são o mais importante meio pelo qual um homem busca influenciar outro; as palavras são um bom método de produzir mudanças mentais na pessoa a quem são dirigidas. Nada mais existe de enigmático, portanto, na afirmativa de que a mágica das palavras pode eliminar os sintomas de doenças, e especialmente daquelas que se fundam em estados mentais.

No mesmo escrito, Freud (1905, p. 301) enfatiza, ainda,

[...] os sentimentos depressivos são muitas vezes suficientes por si mesmos para provocar tanto doenças no sistema nervoso acompanhadas de mudanças anatômicas manifestas, como doenças de outros órgãos. Em tais casos, deve-se presumir que o paciente já tinha uma predisposição, embora até então inoperante, à doença em questão.

Assim sendo, é importante que os sentimentos sejam expressos pelas palavras para que possam ser analisados. Na maioria das vezes o paciente não sabe o motivo da sua mágoa, pois a razão para tal sentimento se encontra reprimida.

O início do tratamento assinala mudança importante na maneira do paciente enxergar o sentimento causador da sua doença, passando a considerá-lo como problema que de fato atrapalha a sua vida. A partir do momento que essa visão é possível, instala-se um caminho que permitirá acesso àquilo que está reprimido. No entanto a empreitada é intensa, pois conforme o que está reprimido vai sendo esclarecido, por aquilo é que dito nas sessões terapêuticas, outros sintomas podem surgir, assustando o paciente. Nesses momentos é importante informar ao paciente 
que se tratam de dificuldades esperadas, porém passageiras, na medida em que vamos contar com obstáculos para alcançar o que está reprimido.

Outra forma de termos acesso ao reprimido é mediante o material obtido pelos testes psicológicos projetivos, na medida em que podemos definir a situação de teste projetivo com base em semelhanças e diferenças em relação à situação psicanalítica.

Iniciando-se pelas semelhanças, temos, tanto na sessão psicanalítica quanto diante de um teste projetivo, o paciente falando livremente, sendo nessa última situação, orientado a falar ou a fazer o que de pronto ocorrer em sua mente, mediante o estímulo que lhe for apresentado, sendo também informado que não há respostas certas ou erradas, considerando-se bom o que ele fizer.

A diferença está no tempo para realizar a atividade. Nas sessões psicanalíticas o tempo é indefinido; apesar do tempo da sessão ser limitado o número de sessões não é estipulado. Por outro lado, diante de um teste projetivo, o tempo de produção é limitado, acarretando em duas diferenças quando comparado com o tratamento psicanalítico: a adição de material prévio e a de inquérito posterior.

Segundo Anzieu (1984, pp.23-24),

Liberdade de expressão e liberdade de tempo constituem, portanto, os dois princípios comuns ao tratamento psicanalítico e à aplicação de testes projetivos. Os dois princípios, no entanto, particularizam-se diferentemente. No caso do teste projetivo, tudo acontece em uma sessão (ou em um número muito pequeno de sessões). As “associações livres” do sujeito devem ser provocadas. Donde decorre a necessidade de lhe apresentar um material desencadeador de tais associações. O material é o mais possível informe ambíguo: manchas de tinta, gravuras vagas, desenhos esboçados, palavras multívocas. As instruções subordinam o sujeito à sua própria vontade: desenhar uma árvore, um personagem, como quiser; organizar cartões coloridos ou peças de um jogo de construção como quiser; escolher, entre fotografias, as que lhe agradam e as que lhe desagradam. Há, igualmente, a necessidade de proceder a um inquérito terminado o teste, a fim de apreender, ao vivo, a dinâmica psíquica pessoal que levou o indivíduo a fornecer as respostas tais como acabou de apresentar.

Os testes projetivos são de grande valia na visualização de aspectos estruturais e/ou dinâmico da personalidade e geralmente são utilizados como integrantes do processo e psicodiagnóstico.

Neste trabalho, utilizaremos o modelo de Psicodiagnóstico proposto por Ocampo (1969), associando entrevista com a aplicação, avaliação e análise de um 
teste projetivo H.T.P. (House, Tree, Person) mediante os pressupostos propostos por Emanuel F. Hammer (1969) e Maria Florentina Godinho Retondo (2000).

A escolha desse instrumento psicométrico ocorreu em função de se tratar de um teste onde é possível verificarmos os aspectos estruturais de personalidade e sua aplicação ser simples, na medida em que, sua tarefa exige que se faça algo que todos nós em algum momento da vida já fizemos: desenhar.

É importante mencionar que na revisão da literatura se constatou que não há trabalhos com dor e nem com o teste projetivo H.T.P., o que nos motiva ainda mais a estudar sobre os fatores de personalidade, implicados no processo doloroso e estimular outros estudiosos a se empenharem no desenvolvimento de mais pesquisas relacionadas ao tema abordado nesta tese.

Outra razão para a escolha do teste projetivo H.T.P. se refere à minha experiência com esse instrumento projetivo gráfico. Lecionei-o durante três anos na Universidade Paulista (UNIP), antiga Faculdade Objetivo.

Durante sete anos fui supervisora da área de estágio em Psicodiagnóstico do curso de Psicologia das Faculdades Metropolitanas Unidas (FMU), hoje Centro Universitário UniFMU. Ao longo desse tempo, o H.T.P. integrou a bateria psicométrica nos Psicodiagnósticos infantis realizados por esse estágio.

No ambulatório da seção de Psicologia do Hospital do Servidor Público do Estado de São Paulo, utilizo-o diariamente nos pacientes submetidos ao Psicodiagnóstico, além de freqüentemente supervisioná-lo no curso de Aprimoramento em Psicologia Clínica e Hospitalar, mantido pela Fundação de Desenvolvimento Administrativo - Fundap. No consultório, também o utilizo na avaliação psicológica dos pacientes que me são encaminhados.

Retomando a questão da dor, constatamos que ela faz parte da vida humana, desde as civilizações mais primitivas e, apesar dos tratamentos para aliviar ou extingui-la datarem de muito anos, as clínicas de dor tiveram seu início na década de 40. O ingresso do profissional da área de saúde mental nas equipes multiprofissionais intensificou a prática da interconsulta.

Segundo Luchina (1971), a interconsulta se caracteriza pela convergência de duas disciplinas que apresentam importantes diferenças quanto a: 1 . critérios de saúde; 2. ideologias; 3. linguagem técnica; 4. modelos de ação; 5. objetivos; 6 . enquadre. 
$\mathrm{Na}$ interconsulta, conforme ressalta Luchina (1971, p.16), observadores de disciplinas diferentes convergem para o mesmo fenômeno: “o estar doente e o curar" e divergem quanto a: 1 . registro dos dados; 2. prioridade e 3. interpretação dos dados. Desse modo, a interconsulta ocorre quando o médico de qualquer especialidade que a solicita, com exceção do médico psiquiatra, presume que há sintomas dentro do quadro geral do paciente que não são atribuídos apenas à sua enfermidade, supondo a existência de aspectos psicológicos interligados à manifestação da sintomatologia apresentada pelo enfermo.

Ao estudo da anatomia e da fisiologia da dor, principalmente da dor crônica, há necessidade de se acrescentar sua complexa subjetividade, garantindo assim, visão da dor na sua totalidade, possibilitando a integração corpo e mente.

O fracasso da conduta exclusivamente médica no tratamento da dor crônica, bem como as atitudes dos pacientes diante do diagnóstico, equipe e procedimento médico, tem levado ao aumento dos pedidos de interconsulta, o que está difundindo cada vez mais a importância do profissional da saúde mental como participante ativo das equipes multiprofissionais.

A década de 50, marco do desenvolvimento da Psicologia Hospitalar, segundo Romano (1999), caracterizou-se como momento áureo para a Psicologia, e a presença do profissional da área da saúde nas clínicas e nos grupos de dor nos hospitais e nas equipes multidisciplinares possibilitou a veiculação do psiquismo como um dos fatores a ser considerado na manutenção e intensidade do sintoma doloroso, em alguns quadros clínicos, não mais esperado em função do tratamento médico administrado.

Freud, em 1885, já fazia aportes sobre traumas e dores, empenhando-se para entender o que mais aconteceria além daquilo que constava com o seu saber médico. Voltava sua atenção para aquilo que não podia ser visto, para aquilo que também não era detectado nos exames de autopsia cerebral, e que também não apareceria nos exames mais sofisticados de ultra-sonografia, tomografia e ressonância magnética, se naquela época ele pudesse contar com tal tecnologia, mas que se fazia presente pelos sintomas dos pacientes.

Em 2002, quase dois séculos após o empenho de Freud para compreender os fenômenos psíquicos, deparamo-nos com a questão a ser esclarecida quanto a manutenção da dor em pacientes que mesmo submetidos aos tratamentos propostos 
para o tratamento de hérnia de disco: medicamentos, fisioterapia e cirurgia, continuam sentindo dor. O entendimento dessa problemática nos envolve no compromisso profissional e ético com o paciente, com sua família, com a equipe multidisciplinar da clínica de neurocirurgia do Hospital do Servidor Público do Estado de São Paulo e com a comunidade científica, para ilustrar, mediante os resultados obtidos da integração do material clínico das entrevistas e do teste projetivo, identificar e ressaltar os traços de personalidade que estariam interferindo na dor crônica e contribuir para a reflexão sobre a sua subjetividade e para futuros trabalhos de profissionais interessados em dar continuidade ao estudo da dor crônica.

Este trabalho se encontra dividido em três partes, visando facilitar a sua leitura. Num primeiro momento, abordarei o conceito de dor de modo geral, sem preocupação de enfatizar alguma teoria em específico. Depois, a tônica se volta para a compreensão da dor segundo uma leitura freudiana. Por último, encerro esta tese integrando as análises do material clínico obtido nas entrevistas e no teste projetivo H.T.P.. 


\section{O Conceito de Dor}

Entender a dor exige tarefa árdua e gera, naquele que se propõe estudá-la, questionamentos e levantamento de hipóteses que clamam por explicações convincentes. As respostas não se apresentam, em alguns momentos, tão esclarecedoras quanto desejado. O interesse em esclarecer melhor a complexidade da dor foi responsável pela criação da Associação Internacional para o Estudo da Dor, originada em Seattle, nos Estados Unidos.

A definição oficial de dor, elaborada pela Associação Internacional para o Estudo da Dor, datada de 1979 a considera: “Uma experiência sensorial e emocional desprazerosa, associada com real ou potencial lesão de tecido ou descrita em termos de tal lesão” (Carvalho, 1999, p.9).

É bem provável que a experiência sensorial da dor desencadeie reações orgânicas-somáticas e viscerais-reflexas que permitem ao organismo fugir ou evitar o estímulo. No entanto, conforme observou Freud, quando a dor tem sua origem no interior do aparelho psíquico é impossível fugir dela, sendo necessários outros recursos para tratá-la.

Os estudos de Freud sobre a histeria exigiram explicações que transcendiam àquelas do sistema neural, constituindo-se em grande desafio para sua compreensão, na medida em que, nesse tipo de neurose, a dor ocorre independente de estímulo potencialmente lesivo, chamando-nos a atenção desde 1895 para a subjetividade da dor.

Retomando a definição de dor da Associação Internacional para o Estudo da Dor podemos pensar em dois tipos de dor: 1. orgânica, onde o substrato físico, apesar de ser bem determinado, recebe influência dos fatores de personalidade, principalmente no que se refere às alterações de humor; 2. psicogênica, cuja origem é exclusivamente psíquica. 
É importante considerar que a dor psicogênica não significa invenção ou mentira do paciente. Quando alguém se queixa de dor realmente sente dor, e cabe aos profissionais da saúde entender qual é o propósito dessa dor para quem a sente.

Kovács, citada por Carvalho (1999, p.320), aponta a importância de sabermos "qual o sentido e o significado que o indivíduo atribui à sua dor, e qual o espaço que ela ocupa em sua vida”.

Saunders, citada por Carvalho (1999, p.318), uma das pioneiras na clínica de cuidados paliativos, define dor como uma dimensão além do físico, abrangendo as esferas emocional, social e espiritual. Acrescenta na sua definição, ainda, os aspectos financeiro, interpessoal, familiar e mental.

A dor orgânica se divide, também, em dor aguda, sinalizando a existência de doença, e em dor crônica, que é desabilitadora e ocasiona transtornos no sono, no trabalho, na movimentação e de ambulação. Compromete ainda o humor e altera, de modo significativo, a atenção e a concentração; interfere e prejudica as relações familiares e a atividade sexual. Nesse sentido, questionar-se-ia se a dor crônica estaria a favor da preservação da vida, na medida em seus males desestabilizam a pessoa, trazendo conseqüências danosas para seu desenvolvimento.

Os aportes e definições sobre dor são unânimes em considerar o caráter singular da experiência dolorosa, na medida em que a dor traz em si uma história de vida marcada por alegrias, vitórias, decepções, perdas, conflitos familiares, dúvidas vocacionais, fracassos amorosos, desorganização psíquica, enfim vivências que se adicionam, ou não, à dimensão física da dor, que se afinam, ou não, com os estímulos potencialmente lesivos.

Segundo Carvalho (1999, p.10): “a dor freqüentemente se torna um problema a resolver”. Tal afirmação retrata a necessidade da Neurocirurgia do HSPE, onde a dor, principalmente a causada pela hérnia de disco, apareceu exatamente como problema a ser resolvido e a ânsia de auxiliar na solução dessa problemática originou esta tese de Doutorado.

Na medida em que dor é uma experiência subjetiva e a dor crônica se compõe de constituintes afetivos, cognitivos, motivacionais e somáticos, é imprescindível que, ao avaliarmos a dor, consideremos os aspectos psíquicos e suas interferências no comportamento do ser humano. 
O tratamento do paciente com dor crônica se encontra diretamente relacionado ao esclarecimento da subjetividade. Assim sendo, intervenções psicológicas podem evitar procedimentos invasivos e, por vezes, desnecessários aos pacientes, além de medida econômica para as instituições hospitalares.

John Bonica criou a primeira clínica de dor no Takoma General Hospital e desenvolveu o conceito multidisciplinar de dor; em 1960, fundou a primeira clínica multidisciplinar de dor em Washington. Pouco tempo depois da mobilização de Bonica em prol da multidisciplinaridade no tratamento da dor, a Commission on Accredition of Rehabilitation Facilities determinou padrões para todos os tipos de programas de tratamento de dor e estabeleceu que deveria existir um profissional da saúde mental em equipes multidisciplinares no tratamento da dor.

As observações de Ogden (1996), citado por Carvalho (1999, p.199), esclarecem a razão da existência do profissional, psicólogo e/ou psiquiatra como integrante de uma equipe que pretende tratar dor:

1. Os tratamentos para dor, baseados exclusivamente no aspecto físico, não eram eficazes; 2. Os médicos observavam que pacientes com mesmo grau de lesão tecidual não evidenciavam a mesma intensidade dolorosa e as reações a esse estímulo nocivo não eram homogêneas; e 3. A presença da dor fantasma em indivíduos que perdiam um membro do corpo não apresentava explicações físicas capazes de esclarecer o fenômeno.

Teixeira, citado por Carvalho (1999, p.81), considera:

O fenômeno fantasma se caracteriza pela sensação da imagem, geralmente distorcida, quanto às dimensões e conformações (macrossomia, microssomia, telescopagem) do órgão amputado. O fenômeno pode ser estático ou dinâmico (cinético, cinestésico). A dor no membro fantasma se caracteriza pelo acoplamento das sensações de queimor, formigamento, choques ou latejamentos sobre a imagem do órgão fantasma. Sensações similares ocorrem em doentes que apresentam neuropatias plexulares branquiais e lombossacrais.

Nasio (1997, p.31) denomina de "fenômeno do amado fantasma" o que os neurologistas chamam de membro fantasma.

Diante da amputação de uma parte do corpo ou da perda de alguém com que estávamos afetivamente envolvidos, a imagem psíquica desses objetos é, por compensação, intensamente superinvestida. O superinvestimento afetivo da imagem gera, além da dor, a alucinação do objeto perdido. A desproporção do superinvestimento é tão acentuada que lança a imagem do objeto perdido para fora 
do eu. E é fora do eu que a representação reaparecerá sob a forma de fantasma. O maior obstáculo à compreensão da dor reside na sua complexidade e leva cada vez mais estudiosos, pesquisadores, médicos, psicólogos, enfim profissionais da saúde a se mobilizarem em prol da sua decifração.

Ao longo da empreitada que estamos nos propondo a realizar com o objetivo de melhor entender o mistério da dor, deparamo-nos com o modelo biopsicosocial da avaliação psiquiátrica da dor crônica, que compreende aspectos subjetivos da experiência da dor, fatores culturais, étnicos e lingüísticos.

Segundo o psiquiatra Cukierman (2001, p.168):

As três categorias de associação entre dor e patologia psiquiátrica são: 1. a dor secundária à patologia psiquiátrica ou às condições psicológicas; 2. a patologia psiquiátrica secundária a dor; e 3. a dor e a co-morbidade (doença médica e psiquiátrica concomitante, sem relação de causa e efeito).

Sonenreich e Estevão (1999), citados por Silva e Terroni (2000, p.203), mencionam que “dores, batimentos cardíacos irregulares e manchas vermelhas pelo corpo são sintomas presentes na depressão”. Reiteram os autores que as manifestações dolorosas na depressão podem ser compreendidas como expressão do estreitamento do campo vivencial e lentificação dos processos psíquicos.

Eles observam que "o deprimido se mostra parado, encolhido, refere-se mais a seus pormenores: coração, estômago que ao corpo inteiro. [...] O paciente mais estreitado vivencia de maneira dominante, quase exclusiva, dados referentes ao próprio corpo" (2000, p.203).

O trabalho de Silva e Terroni (2000) evidencia que cerca de $20 \%$ a $30 \%$ dos pacientes com dor crônica possuem transtorno psiquiátrico diagnosticado no eixo I do DSM (Diagnosis and Statical Manual of Mental Disorders). Os autores constataram que depressão, ansiedade e transtornos somatoformes são algumas manifestações presentes nesses indivíduos. Verificaram, ainda, que a prevalência de depressão maior em pacientes com dor lombar crônica é de três a quatro vezes maior do que na população geral.

Segundo Silva e Terroni (2000, pp.203-204):

A depressão não é simplesmente uma condição co-mórbida, ela interage com a dor crônica e aumenta a morbidade e a mortalidade. Estes pacientes se referem à dor de maior intensidade, menor controle sobre a vida e maior uso de estratégias passivo-evitativas de enfretamento. 
Exibem mais conduta de dor do que os pacientes com dor não-deprimidos. A presença de depressão no pré-operatório da dissectomia lombar é preditiva de uma pobre evolução cirúrgica em um ano de seguimento.

Perissinotti (2001, p.182) pesquisou pacientes do Centro Multidisciplinar de Dor da Clínica Neurológica, do Instituto Central do Hospital das Clínicas da Faculdade de Medicina da Universidade da São Paulo, com o objetivo de avaliar e analisar as necessidades, expectativas, propostas e sugestões dos pacientes com dor crônica. Concluiu:

Que os doentes com síndromes dolorosas, de origem músculo-esquelética, preferiram as respostas que associavam a atenção que o profissional de saúde lhes dirigia, independente da eficácia objetiva do tratamento. Isso nos leva a pensar que esses doentes, além da patologia dolorosa objetiva, sofrem da dor da alma, d'Existir.

Kovács (2001, p.184) ressalta que fatores emocionais podem aumentar ou diminuir a experiência da dor. Assinala a autora que o medo causa contração tanto física quanto psíquica, aumentando a sensação dolorosa. Menciona ainda que "o sentimento de falta de controle, o desamparo, o sentir-se abandonado, isolado e não compreendido também são fatores que podem fazer 'doer' mais'”.

Silva e Terroni compartilham da opinião de Kovács, na medida em que consideram os comportamentos afetivos como parte e parcela da experiência da dor.

Menninger (1965), em seu livro Eros e Thanatos - O homem contra si próprio, citado por Carvalho (1999, p.321), assinala que quando a dor está relacionada a um comportamento auto-destrutivo há que se considerar três aspectos: 1. elemento agressivo (hetero e auto); 2. elemento punitivo (hetero e auto); e 3. elemento erótico. No que se refere ao elemento agressivo, a dor e o sofrimento são usados contra si próprio, de modo explícito ou latente. A pessoa se acidenta com freqüência e com facilidade, devido à displicência na consideração às normas de segurança.

Nas circunstâncias em que a dor se associa ao elemento punitivo, geralmente, o sofrimento se faz necessário para suavizar o sentimento de culpa. A pessoa reage de modo semelhante ao mencionado ou, de forma mais indireta, adoecendo. Quanto ao elemento erótico, ocorre prazer no sofrimento, na doença, dificultando a melhora do paciente. 
Menninger (1965), citado por (Carvalho,1999, p.322), salienta, ainda, quanto à busca do mal menor:

Certos comportamentos auto-destrutivos, entre os quais certas doenças ou síndromes dolorosas podem se apresentar como forma de aliviar um outro sofrimento, que pode ser ainda mais intolerável, como a separação da pessoa amada ou a perda por morte. [...] A doença, nesse caso, pode ser vista como forma de anestesia. Uma dor, aparentemente menor, ocupa o lugar de uma dor que é insuportável.

Do ponto de vista psicanalítico, não há diferença entre dor física e dor psíquica, na medida em que a dor é um fenômeno misto, que tem origem no limite entre o corpo e a psique. Conforme a abordagem psicanalítica, a dor só pode ser compreendida quando é traduzida em sua forma simbólica.

A compreensão simbolizada da dor se realiza com a transferência, e as palavras de Nasio esclarecem como isso é feito: “Dar sentindo a uma dor insondável é, finalmente, construir para ela um lugar no seio da transferência, onde ela poderá ser clamada, pranteada e gasta com lágrimas e palavras” (1997, p.17).

Nasio divide a dor em três grandes categorias: 1 . como afeto; 2. como sintoma; e 3. como perversão. Menciona que a dor é um afeto, pois enquanto há dor, também temos forças para combatê-la e continuar a viver.

A dor, como sintoma, é a manifestação exterior e sensível de uma pulsão inconsciente. Exemplo dessa segunda categoria seria a dor no corpo, revelando a existência de sofrimento inconsciente. A última categoria se refere à dor como objeto e alvo do prazer sexual perverso, sadomasoquista.

A associação entre dor crônica, angústia e depressão permite reflexão produtiva na tênue escalada para a compreensão do fenômeno dor. Entende-se a dor crônica como reação às ameaças do aqui e agora, a angústia como resposta às ameaças futuras e a depressão como sentimento voltado para o passado.

Segundo McDougall (1989, p.158):

A função biológica da dor consiste em fornecer informações importantes à psique, informações que dizem respeito tanto ao corpo e às suas necessidades urgentes, como à antecipação de uma situação de estresse psicológico ou de privação iminente. Se esse elo privilegiado estiver enfraquecido, ou mesmo totalmente cortado, as conseqüências podem ser graves. Sentimentos eventuais de desamparo, desespero, angústia, culpa, raiva podem permanecer fora da psique e, por conseguinte, incapazes de alertarem o sujeito, impossibilitando-o de refletir para então agir. 
A perda da capacidade de sentir e representar a dor constitui séria ameaça para a integridade psíquica e biológica.

O trabalho no hospital nos coloca diariamente diante da dor: do paciente, da sua família, da equipe e da nossa própria.

Esta tese pretende identificar as possíveis razões psicológicas que influenciam na atitude de algumas pacientes frente à dor nas costas causada pela hérnia de disco. Certos pacientes são operados e retornam ao ambulatório da neurocirurgia se queixando de dor, dando a impressão que a cirurgia em nada serviu para cessar, ou pelo menos aliviar, a dor. Outros, apesar de não terem indicação, insistem com os médicos para serem submetidos à cirurgia na medida em que acreditam ser essa a única prescrição para aliviar de modo significativo a dor. A crença acentuada na cirurgia como sendo a técnica que eliminará o desconforto doloroso faz com que esses pacientes não se submetam a fisioterapia nem tampouco tomem os remédios conforme a orientação médica.

Assim sendo, as queixas de dor desses pacientes transcendem o terreno médico e parecem atingir o terreno mental, demandando estudo para esclarecer quais seriam as questões intrapsíquicas implícitas nas insistentes solicitações dos pacientes para a cirurgia; possibilitando ainda a reflexão a respeito de condutas terapêuticas mais efetivas para esses pacientes. 


\title{
III. O Referencial Psicanalítico na Compreensão da Dor
}

\author{
a) A dor segundo a leitura de Freud
}

O pedido do Serviço da Neurocirurgia nos lembra a inquietude de Freud nos primórdios da sua especulação sobre o aparelho psíquico. Os neurologistas estão intrigados com a manutenção da dor em pacientes que, em princípio, estariam livres da sintomatologia dolorosa por meio dos procedimentos médicos utilizados, como medicação, fisioterapia, hidroginástica, acupuntura e cirurgia. Todavia, há algo que o orgânico por si só não responde, mobilizando os médicos neurologistas a buscarem na Psicologia a explicação para a continuidade da dor nesses pacientes.

A possível causa para a permanência da dor nos parece da ordem do mental e, para que possamos entendê-la, se faz necessário a compreensão da subjetividade da dor. O trajeto na busca desse objetivo é complexo e denso e a obra de Freud aparece como alento ao alcance de tão árdua tarefa.

Proponho reflexão sobre alguns textos de Freud que nos ajudarão a pensar a dor e, nesse sentido, auxiliar na orientação terapêutica às pacientes envolvidas nesse trabalho. A retrospectiva dos trabalhos freudianos visando a compreensão do psiquismo se inicia em 1891, com o trabalho sobre afasias, onde pela primeira vez Freud menciona que pessoas sem alteração neurológica poderiam apresentar distúrbios afásicos devido a perturbação psicológica. Essa desordem psicológica alteraria a linguagem, a memória e os processos de representação e de associação da fala.

Projeto para uma Psicologia Cientifica (1950[1895]/1969), além de marcar o início da mobilização de Freud na compreensão do aparelho psíquico, é também uma tentativa de Freud na elaboração de um modelo energético do sofrimento corporal. 
Esse trabalho evidencia a insatisfação de Freud com os modelos anatômicos e neurológicos da época, mobilizando-o para elaborar a metapsicologia.

Freud inicia Projeto Para Uma Psicologia Científica (1895/1969, p.396) estabelecendo dois teoremas. Um se relaciona com noção de quantidade (Q), onde os processos psíquicos são considerados “como estados quantitativamente determinados de partículas materiais especificáveis, dando assim a esses processos um caráter concreto e inequívoco”. Essa hipótese se derivou da observação clínica de casos onde a presença de idéias excessivamente intensas eram considerados patológicas.

O segundo teorema se refere à teoria dos neurônios, considerando que:

O sistema nervoso se compõe de neurônios diferentes, homogêneos em sua estrutura, que se mantém em contato mediante substância estranha, terminando uns sobre os outros como se fossem pedaços de tecido estranho, [e] nos quais se acham estabelecidas determinadas vias de condução, no sentido de que eles [os neurônios] recebem [estímulos] através dos processos celulares [dendrites] e [deles se descarregam] ${ }^{1}$ através de um cilindro-eixo [axon]. Além disso, possuem inúmeras ramificações de vários calibres (Freud, 1950[1895]/1969, p.398).

Freud menciona dois sistemas de neurônios: um, permeável e que, portanto, não estabelece resistência a nada, e são destinados à percepção, e outro, impermeável e dotado de memória e dos processos psíquicos em geral. O primeiro grupo de neurônios Freud denominou de phi $(\phi)$ e o segundo de psi $(\psi)$.

A compreensão do conceito de quantidade (Q) ainda se faz do ponto de vista médico, tanto que no Projeto não se encontra menção à energia psíquica, mas sim a uma energia do sistema neuronal, denominada por Freud de excitação. Desse modo, a compreensão da dor nesse trabalho se faz mediante o esclarecimento da complexidade neuronal e a sua relação com o nível de estimulação externa, representada pelos estímulos ambientais, e a estimulação interna, caracterizada pelos afetos e sensações de desprazer.

Apesar da terminologia Q e Qn não ser bem definida no Projeto, apreende-se que Q se refere à excitação exógena oriunda do mundo externo e Qn está relacionada à energia de fonte endógena de magnitude intercelular e inferior a Q.

O sistema nervoso está constituído de tal maneira que as grandes Qs ficam afastadas de $\phi$ e de $\psi$ pelas telas de terminação nervosa, submetendo o

\footnotetext{
${ }^{1}$ No manuscrito esta 'abnehmen' (se desprendem), provavelmente lapso de escrita, corrigido nos Anf.,382, para 'abgeben’ (se descarregam).
} 
funcionamento do sistema nervoso ao princípio da inércia. Sob o domínio do princípio da inércia os neurônios tendem a livrar-se de qualquer quantidade que possam estar cheios. A dor representa o fracasso nesses dispositivos, movimentando os dois sistemas de neurônios, o $\phi$ e o $\psi$, não havendo obstáculo algum a sua condução.

Para Freud (1950[1895]/1969, p.409),

As causas precipitadoras da dor são, de um lado, o aumento da quantidade: toda excitação sensível, mesmo a dos órgãos sensoriais mais suscetíveis, tende a se transformar em dor quando o estímulo aumenta [...]. Por outro lado, a dor se manifesta quando a quantidade externa é mínima, e nesses casos aparece sempre vinculada a uma interrupção da continuidade $^{2}$. Isto é uma $\mathrm{Q}$ externa, que atua diretamente sobre as terminações dos neurônios $\phi$ e não através dos sistemas de terminações nervosas, produz a dor. A dor fica assim caracterizada como uma irrupção de Qs intensas em $\phi$ e em $\psi$ : isto é, de Qs que pertencem a uma ordem de magnitude ainda maior que a dos estímulos $\phi$. [...] A dor deixa facilitações permanentes atrás de si em $\psi$ - como se tivesse sido atingida por um raio -, facilitações que derrubam por completo as resistências das barreiras de contato estabelecendo uma via de condução ali [em $\psi]$ como as que existem em $\phi$.

Essa divisão dos neurônios constituiu as bases de complexas explicações fisiológicas como o funcionamento da memória, percepção da realidade, o processo do pensamento e também os fenômenos de sonhar e da desordem psíquica. Essa dinâmica neuronal, todavia, não esclarece quanto a qualidade de excitações que chegam no aparelho psíquico.

Freud supõe, então, a existência de um terceiro sistema de neurônios $\omega$ (Omega), responsável pela qualidade.

Garcia-Roza (2001, p.109) esclarece o mecanismo da qualidade da seguinte maneira:

Toda percepção excita $\omega$; como $\omega$ não retém Qn, por menor que essa seja, produz-se uma descarga ocorrida em $\omega$ que funcionará como signo de qualidade e também como signo de realidade em psi.

A estimulação do mundo externo atinge os neurônios $\phi$ e a partir dele uma parte dessa estimulação é descarregada e a outra é transferida para outros sistemas. Entre $\omega$ e o mundo externo, além dos órgãos dos sentidos se encontra o sistema $\psi$ de

2 ‘Continuitatstrennung’ no original. O sentido não e completamente claro. 
neurônios que amortecem a estimulação. Assim sendo, o equilíbrio do aparelho psíquico depende do sistema $\psi$.

O fato da excitação vinda do exterior ser absorvida em $\phi$ e não por $\omega$ não possibilita a compreensão das sensações conscientes de prazer e desprazer pela intensidade da estimulação. O sistema $\omega$, sistema da consciência, recebe um mínimo de excitação, o suficiente apenas para indicar a realidade ao sistema $\psi$.

Conforme Freud (1895/1969, p.424), a dor produz em $\psi$ :

1. aumento de tensão que é sentido como desprazer em $\omega^{3} ; 2$. propensão à descarga, que pode estar modificada em determinados sentidos; e 3. facilitação entre essa ultima descarga e uma imagem mnêmica do objeto que acentua a dor.

Desse modo, a dor propicia quantidade e qualidade em $\psi$, sendo essa última fornecida pelo sentimento de desprazer em $\omega$. Certamente, hoje, os princípios da neurologia para entender a dor não combinam com os propostos por Freud. Os avanços no desenvolvimento da medicina propiciam maior precisão para conhecer as características da dor, identificar a sua causa e tratá-la.

No entanto, cabe ressaltar que os escritos, em Projeto para uma Psicologia Cientifica (1950[1895]), mencionam, sobretudo em carta à Fliess, datada de abril de 1905, o empenho de Freud para formular uma teoria que explicasse o funcionamento psíquico. Desse modo, os conceitos neurológicos dessa época caracterizaram de onde Freud partiu para a concepção de sua complexa teoria sobre o aparelho psíquico.

Na vivência da dor, a imagem do objeto é reinvestida, ocasionando o desprazer que precisa ser descarregado. Esse desprazer não é a dor, mas algo que a ela se assemelha. Freud denominou essa semelhança dor de afeto. A designação afeto é utilizada para representar a reprodução de uma vivência de dor, o que implica desprazer e não dor.

Todo desprazer se relaciona a aumento de nível de Qn, porém no caso presente sua origem não é externa, uma vez que o objeto que causou a dor não está presente. No caso da dor, o aumento de Qn era provocado pela Q externa, enquanto na repetição da vivência de dor a Q externa não está presente.

\footnotetext{
${ }^{3}$ Cf. Inhibitions, Symptoms and Anxiety (1920), Standard Ed.20,171-2.
} 
A dor e o prazer não significam pólos opostos, e a dor pode constituir-se parte da vivência prazerosa, quando se associa ao prazer sexual. Esse assunto será abordado quando discutirmos o tema do masoquismo.

Freud ainda está preso às explicações neurológicas para compreender o desprazer, e os conceitos de afeto de estados de desejos são entendidos como os responsáveis de tensão em $\psi$. Mais tarde, em Sobre O Narcisismo: Uma Introdução (1914), a série prazer/desprazer origina o princípio do prazer.

Na segunda parte de Projeto para uma Psicologia Científica (1895/1969, p.457), Freud escreve sobre a psicopatologia dos fenômenos histéricos, evidenciando que os pacientes histéricos estão sujeitos a uma repetição exercida por idéias excessivamente intensas. As pacientes histéricas evidenciam uma repetição, devido às idéias excessivamente intensas, que podem surgir na consciência sem que haja fatos que justifiquem sua presença.

No entanto, Freud (1950[1895]/1969) observou que a repetição histérica se soluciona quando é esclarecida. Em seus estudos, constatou que para cada repetição há um recalcamento correspondente e a cada intrusão excessiva na consciência ocorre uma amnésia correspondente.

A gênese da repetição histérica se origina de um tipo especial de movimento de Q, que se procede na dicotomia repetição e recalque. O recalcamento desperta no ego idéias desprazerosas que se referem à vida sexual. $\mathrm{O}$ afeto que causa desprazer no ego é o responsável pelo recalque, e Freud, em Projeto para uma Psicologia Cientifica (1950[1895]/1969, p.461), propõe duas hipóteses para essa afirmação:

1. que a catexia desse neurônio certamente não era a que estava sendo procurada, quando o processo de pensamento, visava, a princípio estabelecer uma situação de satisfação em $\psi$; e 2. que quando uma experiência de dor é terminada de maneira reflexiva, a percepção hostil fica substituída por outra.

O recalcamento histérico acontece com o auxílio da formação simbólica, do deslocamento para outros neurônios. Freud (1950[1895]/1969, p.469) atribui nesse momento dois determinantes para essa defesa patológica: “1. que a liberação sexual provinha de uma lembrança e não de uma experiência; e 2. que a liberação sexual ocorria prematuramente”.

A função sexual está presente desde o início da vida da pessoa, e é auto-erótica. Freud denominou de libido a energia dos impulsos sexuais e quando essa energia é 
recalcada aparecem os sintomas. A sexualidade não se refere apenas aos órgãos sexuais, tendo uma função corpórea mais abrangente, ligada ao prazer, e só mais tarde se vincula à função de reprodução.

Segundo Freud, em Sobre o Narcisismo: Uma Introdução (1914/1969, p.100), qualquer parte do corpo pode enviar estímulos sexuais à mente, sendo essa atividade denominada de 'erogenicidade’, “bem como outras partes do corpo - as zonas erógenas - podem atuar como substitutos dos órgãos genitais e se comportarem analogamente a eles”. Assim sendo, a erogenicidade é uma característica geral de todos os órgãos, o que nos permite falar em aumento ou diminuição dela numa parte específica do corpo. Mudança na erogenicidade do órgão corresponde a mudança na catexia libidinal do ego.

Em Sobre o Narcisismo: Uma Introdução (1914/1969), o surgimento do ego caracteriza a distinção entre auto-erotismo e narcisismo. No narcisismo, há a presença do ego possibilitando dois tipos de escolha de objeto. A escolha narcísica se relaciona à maior concentração da libido no ego, enquanto a ligação anaclítica revela o deslocamento da libido para os objetos externos ao ego.

Ainda em Sobre o Narcisismo: Uma Introdução (1914/1969, p.92), Freud menciona que há uma

[...] Antítese entre a libido do ego e a libido objetal ${ }^{4}$. Quanto mais uma é empregada, mais a outra se esvazia. A libido objetal atinge sua fase mais elevada de desenvolvimento no caso de uma pessoa apaixonada, quando o indivíduo parece desistir de sua própria personalidade em favor da catexia objetal. [...]. Somente quando há catexia objetal é que é possível discriminar uma energia sexual - a libido - de uma energia dos instintos, do ego ${ }^{5}$.

Por outro lado, quando uma pessoa se machuca fisicamente, ou adoece, o movimento da libido é diferente. Nesses casos, ocorre superinvestimento na representação mental do local do machucado. O superinvestimento afetivo e energético do representante psíquico do local do ferimento pode se compreender como uma superexcitação libidinal equivalente ao prazer sexual perverso, “apoiado” sobre uma função fisiológica (Freud,1914, p. 103).

\footnotetext{
${ }^{4}$ Essa distinção é esboçada aqui por Freud pela primeira vez.

${ }^{5}$ Um relato parcial do desenvolvimento dos conceitos de Freud sobre os instintos será encontrado na Nota do Editor inglês a 'Instintos e suas Vicissitudes' adiante, p.131 e segs.
} 
A sugestão de Sandor Ferenczi sobre o adoecimento menciona: "Uma pessoa atormentada por dor e mal-estar orgânico deixa de se interessar pelas coisas do mundo externo, na medida em que não dizem respeito ao seu sofrimento” (1914, p.98).

Essa sugestão, incorporada à teoria da libido do Freud (1914, p.98), seria assim considerada: "O homem enfermo retira suas catexias libidinais de volta para o seu próprio ego, e as põe para fora novamente quando se recupera”.

Durante a recuperação, a libido volta a ser direcionada aos objetos e é importante que esse movimento aconteça, na medida em que o represamento da libido no ego também acarreta desprazer, e o que em principio seria para aliviar a pessoa, pode trazer mais desconforto.

Segundo Freud (1914/1969, p.101), a libido voltaria a ligar-se aos objetos

[...] Quando a catexia do ego com a libido excede certa quantidade. Um egoísmo forte constitui uma proteção contra o adoecer, mas, num ultimo recurso, devemos começar a amar a fim de não adoecermos, e estamos destinados a cair doentes se, em conseqüência da frustração, formos incapazes de amar.

No entanto, independente dessa movimentação, o ego é, segundo Freud (1920/1969, p.72), “o verdadeiro e original reservatório da libido, sendo apenas desse reservatório que ela se estende para os objetos”. E a concentração de toda a libido disponível no ego Freud denominou de narcisismo.

Uma parte do Seminário I de Lacan, citado por Garcia-Roza (2000), com o título “Os dois narcisismos”, aborda o seguinte:

Há um primeiro narcisismo que se relaciona à imagem corporal e um segundo narcisismo que implica a relação com o outro. No primeiro caso, há uma identificação à imagem unificada do próprio corpo e dá lugar ao eu ideal; no segundo caso, há uma identificação ao outro e dá lugar ao ideal do eu (p.66).

No Congresso de Marienbad, em 1936, Lacan formulou pela primeira vez sua teoria do estágio do espelho ${ }^{6}$, como formador da função do eu. Baseando-se no trabalho de Wolfgang Kohler, Lacan observou que a criança, antes de um ano de idade, é superada pelo chimpanzé no que se refere à inteligência instrumental.

${ }^{6}$ Publicado nos Ecrits, Paris, Seuil, 1966, p.93-100. 
Todavia, aos seis meses, a criança é capaz de identificar sua imagem no espelho o que lhe traz muita alegria. Essa condição permite à criança formar uma representação de sua unidade corporal por identificação da imagem do outro, origem do primeiro esboço do eu.

Essa experiência sinaliza um tipo de relação da criança com o outro, pela qual é possível a demarcação da totalidade do seu corpo. O que é devolvido à criança pelo espelho é uma Gestalt, cuja função primordial é a estruturação do seu eu. A vivência do corpo fragmentado, anterior à fase do espelho, cede lugar à primeira delimitação de si por um processo de identificação com o outro.

A mãe é quem vê a criança como corpo único, não fragmentado. Assim sendo, antes do estágio do espelho a mãe já antecipou a constituição do eu. No estágio do espelho, a imagem que a criança tem de si coincide com a visão da mãe, na medida em que se trata de visão de um corpo integrado. Essa visão total do corpo é responsável pelo surgimento do eu. $\mathrm{O}$ eu originado a partir da identificação à imagem do espelho é concebido como representação complexa relacionada à imagem corporal, sendo que essa imagem é a que confere unidade primeira ao sujeito.

A imagem corporal não é a única a fornecer forma ao eu; as enunciações, o juízo de valor, as declarações de preferência ou de rejeição também participam dessa constituição. Essa constituição se efetiva com a revivescência do narcisismo dos pais, atribuindo aos filhos as perfeições e privilégios que eles (pais) tiveram que abandonar, somada à imagem que a criança faz de seu próprio corpo.

A constituição do eu é a base das identificações primárias e secundárias. O eu ideal caracteriza o primeiro tipo de identificação, e o ideal do eu representa a identificação secundária.

Uma perturbação no desenvolvimento da libido é a responsável pela escolha dos próprios eus como objeto de amor, caracterizando uma escolha de objeto narcisista. O desenvolvimento do eu se faz mediante afastamento do narcisismo primário, ocasionado pelo deslocamento da libido em direção a um ideal do eu imposto de fora, sendo a satisfação provocada pela realização desse ideal.

O narcisismo secundário resulta de retorno do eu dos investimentos feitos sobre os objetos externos. A libido que anteriormente investia o eu passa a investir objetos externos, transformando a libido narcísica em libido objetal e posteriormente volta a tomar o eu como objeto, caracterizando o narcisismo secundário. 
A compreensão do narcisismo secundário se faz por meio da diferenciação entre as neuroses e psicoses. Na neurose ocorre represamento da libido no ego, porém sem destituir completamente o interesse erótico nas pessoas e objetos. Essa ligação é preservada na fantasia, substituindo os objetos reais por objetos imaginários. Na psicose, o armazenamento da libido no ego acontece mediante a retirada da libido das pessoas e dos objetos, sem o recurso da fantasia.

Na medida em que já temos um eu e que o seu desenvolvimento se encontra relacionado ao deslocamento da libido para outros objetos e o seu retorno para o ego - narcisismo secundário -, despertamo-nos para o medo de perder o objeto.

A ansiedade sinaliza ao ego sobre os perigos externos e internos, porém ambas as ameaças convergem para a perda do objeto amado ou a perda do seu amor, remetendo o ego ao desamparo. A perda o objeto de amor, bem como a perda do seu amor, são responsáveis por três tipos de reações: ansiedade, luto e dor.

Freud, em Inibições, Sintomas e Ansiedade (1926[1925]/1969, p.195), ajudanos a refletir sobre essas respectivas diferenças.

Quando a uma criança lhe é apresentada uma pessoa diferente da sua mãe, ela manifestará ansiedade, seguindo-se de choro, que pode sinalizar a existência de dor. Para a criança ela nunca mais verá a mãe, uma vez que ainda não distingue entre ausência temporária e permanente do objeto amado. Por meio da brincadeira que a mãe faz de esconder o próprio rosto com as mãos e fazê-lo reaparecer, a criança vai reconhecendo a presença e ausência do objeto, o que lhe permite ir distanciando-se do desespero experimentando mais o anseio. Todavia, a ausência da mãe não é a única experiência traumática para a criança. Há que se considerar que coincidentemente à falta da mãe, ocorre uma necessidade da criança que apenas a mãe poderia satisfazê-la, caracterizando perigo pela perda do objeto, mas não pelo seu amor. Mais tarde, com as experiências na relação com a mãe, a criança aprende que, apesar da mãe estar próxima, ela pode estar aborrecida consigo, surgindo a perda do amor do objeto que representa outro perigo, que é mais duradouro e causador de ansiedade.

As vivencias traumáticas referentes ao sentir falta da mãe e ao nascimento são diferentes na medida em que nesse último o objeto ainda não existia. A partir do nascimento, as variadas situações de satisfação originaram o objeto mãe e sempre que a criança sente sua necessidade sente, segundo Freud (1926[1925]/1969, p.195), ‘anseio'.

A dor ocorre em primeiro lugar e como resposta a um estímulo que irrompe o escudo protetor, passando a atuar como estímulo contínuo contra o qual a ação 
muscular é ineficaz. Esse mecanismo é o mesmo tanto para as dores iniciadas na pele quanto para aquelas provenientes de órgãos internos.

Segundo Freud (1926[1925]/1969, p.197):

Quando há dor física ocorre um alto grau do que pode ser denominado de catexia narcísica do ponto doloroso ${ }^{7}$. [...] Quando há um desvio psíquico ocasionado por algum outro interesse, mesmo as dores físicas intensas deixam de surgir ( não devo dizer 'permanecem inconscientes' nesse caso); pode ser explicado por haver uma concentração de catexia no representante psíquico da parte do corpo que está emitindo dor. [...] Penso ser aqui que encontraremos o ponto de analogia que tornou possível levar sensações de dor até a esfera mental, pois a intensa catexia de anseio que está concentrada no objeto do qual se sente falta ou que está perdido (uma catexia que aumenta com firmeza porque não pode ser apaziguada) cria as mesmas condições econômicas que são criadas pela catexia da dor que se acha concentrada na parte danificada do corpo.

Em Inibições, Sintomas e Ansiedade (1926[1925]/1969, p.197), Freud menciona ainda que:

A transição da dor física para a dor mental exige mudança da catexia narcísica para a catexia do objeto. Uma representação de objeto que esteja altamente catexizada pela necessidade instintual desempenha o mesmo papel que uma parte do corpo catexizada por aumento de estímulo. A natureza contínua do processo catexial e a impossibilidade de inibi-lo produzem o mesmo estado de desamparo mental.

O luto é mais uma forma de reagirmos à perda do objeto de amor. Algumas pessoas reagem frente à mesma falta de modo patológico, caracterizando-se a melancolia. Freud, em Luto e Melancolia (1917[1915]/1969), informa-nos sobre a diferenciação desses dois tipos de reação frente à ausência do objeto estimado.

Freud (1917[1915]/1969, p.276) chamou o luto de ‘doloroso’. No luto, o objeto amado não existe mais e exige que as ligações libidinais sejam retiradas dele (objeto perdido). "Cada lembrança do objeto ao qual a libido se encontra ligado é evocada e hipercatexicada e o desligamento da libido se realiza em relação a cada uma delas”» (Freud, (1917[1915])/1969, p.277).

\footnotetext{
${ }^{7}$ Cf. Sobre o Narcisismo (1914c), Edição Standart Brasileira, Vol. XIV, p.98, Imago Editora, 1974.

${ }^{8}$ Essa idéia parece vir expressa já em estudos sobre a histeria (1895d): encontrar-se-á a descrição de processo semelhante a este perto do início da 'Discussão' de Freud sobre a
} 
O luto se inicia com a dor viva da perda do objeto amado e termina com a possibilidade de aceitação do seu real desaparecimento. Ao longo do processo do luto, o eu desinveste pouco a pouco do objeto querido, até que a sua representação perca a vivacidade e deixa de ser um corpo estranho para o eu. O desinvestimento da representação do objeto amado, porém perdido se faz mediante a retirada do excesso de afeto, para que esse sentimento seja redirecionado para outro objeto.

A dor no luto é a dor da saudade do objeto perdido, já que momentaneamente pode acontecer um reinvestimento em razão de algo que lembrou o objeto ausente. A dor volta nesse momento em que a representação do morto é revivida pela lembrança. A elaboração do luto absorve o ego, submetendo-o à inibição e à falta de interesse.

Na melancolia a perda é de um objeto ideal. O objeto não morreu, mas se perdeu como objeto de amor. Freud (1917[1915]/1969, p.277) esclarece que na melancolia “o paciente sabe quem perdeu, mas não o que perdeu nesse alguém”.

Para Freud (1917[1915]/1969, p.276), os traços mentais da melancolia são: [...] Desânimo profundamente penoso, cessação do interesse pelo mundo externo, perda da capacidade de amar, inibição de toda e qualquer atividade e diminuição dos sentimentos de auto-estima, a ponto de encontrar expressão em auto-recriminação e auto-envelhecimento, culminando numa expectativa delirante de punição. As características do luto são semelhantes à da melancolia, com exceção da auto-estima, pois no luto a pessoa não perde a auto-estima.

Na melancolia existe identificação com o objeto perdido. Ao invés da libido investida no objeto perdido ter sido desviada para outro objeto, recolheu-se no eu, estabelecendo identificação do eu com o objeto abandonado, constituindo-se a perda do eu. Segundo Freud, essa situação se deve à escolha de objeto com base narcísica, que se converte em identificação narcísica, razão pela qual o investimento de objeto volta ao narcisismo quando enfrenta algum obstáculo.

A dor é uma das reações à perda do objeto, bem como à perda do seu amor; para compreendê-la melhor se faz necessário retomarmos o Projeto Para uma Psicologia Cientifica (1950[1895]/1969). Nesse texto, os neurônios $\psi$ são alimentados por uma fonte exógena, pelo sistema $\phi$ de neurônios, e outra endógena,

anamnese de Fraulein Elizabeth von R. (Edição Standard Brasileira, Vol. II, p.211, Imago Editora, 1974. 
que atinge diretamente o sistema $\psi$ de neurônios. Assim sendo, as excitações vindas do externo não atingem o sistema $\psi$, pois os órgãos dos sentidos funcionam como tela de proteção contra as quantidades (Q) intensas.

No entanto, essa segurança não acontece quando a excitação é endógena. Nessas circunstâncias o sistema $\psi$ se encontra em conexão direta com as vias por onde chegam as excitações endógenas, ficando sem defesa às Q (quantidades) originárias do próprio corpo. Os órgãos do corpo são as vias dessas excitações endógenas e também a origem exclusiva das pulsões.

As pulsões agem no aparelho psíquico buscando satisfação imediata por meio do objeto e se fazem presente de duas maneiras: 1 . submetendo-se à soberania do principio do prazer e 2. estando além do principio do prazer. Considerando-se o aparelho psíquico como sendo o lugar da ordem devido ao principio do prazer e da realidade, as pulsões distanciadas desses domínios caracterizariam o caos.

Dentre as vicissitudes pelas quais as pulsões passam ao longo do processo de desenvolvimento, deter-nos-emos à dicotomia sadismo-masoquismo, uma vez que se encontra relacionada à dor.

A compreensão desses opostos, sadismo-masoquismo, requer investigação mais amiúde dos seguintes aspectos, ressaltados em Os Instintos e suas Vicissitudes (1915/1969, p.148):

1. o sadismo consiste no exercício de violência ou poder sobre uma outra pessoa como objeto.

2. Esse objeto é abandonado e substituído pelo eu do individuo. Com o retorno em direção ao eu efetua-se também a mudança de uma finalidade instintual ativa para uma passiva. 3. Uma pessoa estranha é mais uma vez procurada como objeto; essa pessoa, em conseqüência da alteração que ocorreu na finalidade instintual, tem de assumir o papel do sujeito ${ }^{9}$.

Promover dor não é da responsabilidade das ações intencionais originais do instinto. Todavia, ocorrida a transformação em masoquismo, a dor proporciona finalidade masoquista passiva. Segundo Freud, a dor, bem como as sensações

\footnotetext{
${ }^{9}$ Embora o sentido geral desses trechos seja claro, pode verificar-se certa confusão no uso da palavra 'sujeito'. Em geral ‘sujeito' e 'objeto' são empregados, respectivamente, para a pessoa na qual um instinto (ou outro estado de espírito) se origina, e a pessoa ou coisa para a qual é dirigido. Aqui, contudo 'sujeito' parece ser utilizado para a pessoa que desempenha a parte ativa da relação - o agente. A palavra é mais obviamente utilizada com esse sentido no trecho da p.150 mais adiante.
} 
desagradáveis, aproximam-se da excitação sexual, transformando o desagradável em agradável, razão pela qual o desconforto da dor é tolerado.

$\mathrm{O}$ eu transforma a linguagem das pulsões em linguagem dos sentimentos, captando as modulações pulsionais e arremessando-as na tela da consciência, sob a forma de emoções. Quando essas modulações são moderadas elas se tornam conscientes, aparecendo na forma de sentimentos de prazer e de desprazer; e quando elas são extremas, se transformam em dor.

O que seria então responsável pelo aumento acentuado das modulações pulsionais, gerando dor? A perda do objeto de amor tem papel importante na alteração do nível dessas modulações. Diante da ausência desse objeto o eu percebe no seu interior o transtorno das tensões incontroláveis, portanto, o eu sente dor.

E importante frisar que desprazer não é dor, apesar de pertencerem à mesma categoria de sentimentos penosos. O desprazer é uma sensação que sinaliza à consciência um aumento de tensão pulsional, porém ainda dominada pelo princípio do prazer. A dor é o caos da vida psíquica, onde o princípio do prazer não é mais soberano. Portanto, a dor não está diretamente relacionada à perda do objeto de amor, mas, sim, às conseqüências dessa perda para as pulsões, tornando-as completamente descontroladas.

Em 1920, à teoria das pulsões é acrescido o conceito de pulsão de morte. Freud, porém, concebeu aos órgãos do corpo a origem das pulsões. Apesar de todas as pulsões terem a mesma origem, Freud estabeleceu distinção entre pulsão de autoconservação ou pulsão do eu e as pulsões sexuais. Enquanto as últimas se destinam ao prazer do órgão, as primeiras se voltam para a autoconservação da pessoa.

O conceito de pulsão de morte significa o caos pulsional, ao contrário da ordem psíquica, ocasionando a queda da hegemonia do princípio do prazer. O princípio do prazer é soberano no que se refere ao funcionamento do aparelho psíquico, porém aquilo que está além do princípio do prazer é destrutivo, cedendo lugar à emergência de novas formas.

É importante discutir a relação do princípio do prazer com a pulsão de vida e com a pulsão de morte, para que possamos compreender a tendência masoquista na vida do ser humano. 
Em Projeto Para uma Psicologia Científico (1950[1895]/1969), a explicação para a dor enfatizava o excesso de quantidade de excitação que mobilizava o sistema de neurônios psi acionando a proteção, propiciando então o alívio da excitação diminuindo o desprazer.

Nesse sentido, se há a possibilidade de aliviar a excitação, constatamos o movimento da pulsão de vida e estamos no domínio do principio do prazer.

Freud, em Além do Principio do Prazer (1920/1969, p.83), assinala:

O principio o prazer é uma tendência que opera a serviço de uma função, cuja missão é libertar inteiramente o aparelho mental de excitações, conservar a quantidade de excitação constante nele, ou mantê-la tão baixa quanto possível.

Porém, nesse mesmo escrito, com a introdução do conceito de pulsão de morte, caracterizada por Freud como sendo um quantum de pulsão, que por não se ligar aos objetos não pode ser representada, a hegemonia do Principio do Prazer é destituída. A impossibilidade de lançar-se para fora do ego faz com esse resíduo pulsional se misture à libido e tenha o ego como seu objeto, caracterizando o masoquismo cujo cerne está na pulsão de morte. Desse modo, a pulsão de morte se encontra além do princípio do prazer, cujo destino é levar o que é vivo ao estado inorgânico.

O componente sádico do instinto sexual, sob a forma de perversão, pode dominar a vida sexual de uma pessoa. Em Além do Principio do Prazer (1920/1969, p.74), Freud considera:

Durante a fase oral de organização da libido, o ato de domínio erótico sobre um objeto coincide com a destruição desse objeto; posteriormente o instinto sádico se isola, e, finalmente na fase de primazia genital, assume, para os fins da reprodução, a função de dominar o objeto sexual até o ponto necessário à efetivação do ato sexual. Poder-se-ia verdadeiramente dizer que o sadismo que foi expulso do ego apontou o caminho para os componentes libidinais do instinto sexual e que estes o seguiram para o objeto.

O trabalho clínico levou Freud à seguinte concepção do masoquismo:

O instinto componente complementar ao sadismo deve ser encarado como um sadismo que voltou para o próprio ego do sujeito. O masoquismo, a volta do instinto para o próprio ego do sujeito, constituiria, nesse caso, retorno a uma fase anterior da história do instinto, uma regressão (p.75).

Freud, em O Problema Econômico do Masoquismo (1924/1969, p.204), menciona: 
Nos organismos (multicelulares), a libido enfrenta o instinto de morte ou de destruição neles dominante e procura desintegrar o organismo celular e conduzir cada organismo unicelular separado [que o compõe] para um estado de estabilidade inorgânica (por mais relativa que essa possa ser).

Ao lado do instinto para preservar há outro instinto, o de morte, cujo objetivo é remeter a vida ao estado inorgânico. Ambos instintos não estão isolados um do outro e, em O Mal-Estar da Civilização (1930[1929]/1969, p.141), Freud esclarece essa interrelação:

As manifestações de Eros eram visíveis e bastantes ruidosas. Poder-se-ia presumir que o instinto de morte operava silenciosamente dentro do organismo, no sentido da sua destruição, mas isso, naturalmente, não constituía uma prova. Uma idéia mais fecunda era de que parte do instinto é desviada no sentido do mundo externo e vem à luz como instinto de agressividade e destrutividade. Dessa maneira, o próprio instinto podia ser compelido para o serviço de Eros, no caso de o organismo destruir alguma outra coisa, inanimada ou animada, ao invés de destruir o seu próprio eu (self). Inversamente, qualquer restrição dessa agressividade dirigida para fora estaria fadada a aumentar a autodestruição. [...].

A libido tem o poder de tornar inócuo o instinto destruidor e o realiza levando esse instinto para fora e, com a ajuda do sistema muscular, desvia esse instinto para os objetos do mundo exterior. Uma parte do instinto destruidor se liga à função sexual, caracterizando o sadismo propriamente dito. Outra parte do instinto destruidor permanece dentro do organismo e com o auxilio da excitação sexual permanece libidinalmente preso. Essa porção contida no organismo é denominada de masoquismo erógeno.

Após uma parte do instinto destruidor ter sido deslocado para fora do organismo, a parte que restou se tornou componente da libido e tem o eu como o seu objeto. A atitude de alguns pacientes frente ao tratamento fez com que Freud pensasse em um sentimento de culpa inconsciente, que determinaria apego à doença em detrimento da melhora. Esses pacientes são apegados a uma exagerada moral, tornando-os inibidos.

A avaliação mais apurada entre o apego intenso à moralidade e o masoquismo moral realizada por Freud, em O Problema Econômico do Masoquismo (1924/1969, p.210), evidencia: 
Na primeira, o acento recai sobre o sadismo intensificado do superego a que o ego se submete; na última, incide no próprio masoquismo do ego, que busca punição, quer do superego quer dos poderes parentais externos.

Ainda em O Problema Econômico do Masoquismo (1924/1969, p.211-212), Freud assinala:

A volta do sadismo contra o eu (self) ocorre regularmente onde uma supressão cultural dos instintos impedem que grande parte dos componentes instituais destrutivos do individuo seja exercida na vida. Podemos supor que essa parte do instinto destruidor que se retirou, aparece no ego como intensificação do masoquismo. Os fenômenos da consciência, contudo, levam-nos a inferir que a destrutividade que retorna do mundo externo é também assumida pelo superego, sem qualquer transformação desse tipo, e aumenta seu sadismo contra o ego. O sadismo do superego e o masoquismo do ego se suplementam mutuamente e se unem para produzir os mesmos efeitos.

O perigo do masoquismo moral está no fato de sua origem ser o instinto de morte e corresponder a parte desse instinto que não foi direcionado para fora do aparato psíquico, como instinto de destruição.

Quando a agressividade é internalizada ela volta para o próprio ego. Esse sentimento é assumido por parte do ego, que se coloca contra o restante do ego como o superego, e de modo consciente está pronto para agredir o ego do mesmo modo que ele teria feito às pessoas caso a agressividade tivesse sido manifesta.

À tensão entre o rígido superego e o ego Freud denominou de sentimento de culpa, e sua expressão se faz mediante uma necessidade de punição.

Conforme Freud, o sentimento de culpa se relaciona à intenção de fazer algo mau, e a questão que se coloca é: o que levaria uma pessoa a se sentir culpada quando somente teve a intenção de fazer uma maldade, sem necessariamente ter traduzido essa intenção em fato agressivo contra alguém?

A resposta para tal indagação se encontra no medo do desamparo pela perda do objeto de amor. Se a pessoa perder o amor de outra de quem é dependente, sente-se exposta aos perigos de qualquer ordem. Assim sendo, mau é tudo o que nos faz perder o amor, deixando-nos muito ameaçados.

Com o estabelecimento do superego, a intenção de fazer o mal desaparece, uma vez que nada é escondido do superego, nem tampouco os sentimentos e os desejos. Esperar-se-ia que o superego não teria razões para destratar o ego, mas quando as 
frustrações do cotidiano acontecem o superego eleva as exigências ao ego, impondolhe abstinência e castigando-o com penitências.

As origens do sentimento de culpa são duas. O Mal-Estar da Civilização esclarece que quando uma tendência instintiva experimenta a repressão, seus elementos libidinais são transformados em sintomas e seus componentes agressivos em sentimentos de culpa (Freud, (1930[1929]/1969).

Na neurose obsessiva, o sentimento de culpa se faz ruidosamente, ouvido na consciência; domina o quadro clínico e também a vida do paciente, mal permitindo que apareça algo mais ao lado dele. No entanto, em outras formas de neuroses e até mesmo em algumas manifestações da neurose obsessiva, o sentimento de culpa permanece completamente inconsciente.

Diante da dificuldade dos pacientes entenderem quando lhe falamos desse sentimento de culpa inconsciente, procuramos falar de necessidade de punição, onde esse sentimento de culpa encontra expressão.

Uma se refere à ameaça de infelicidade externa ocasionada pela perda do amor e castigo por parte da autoridade externa. A outra é a infelicidade interna permanente devido à tensão do sentimento de culpa (Freud, (1930[1929]/1969).

O medo do superego, a necessidade de punição constituiu manifestação instintiva por parte do ego, que se tornou masoquista sob a influência de um superego sádico; é, por assim dizer, parcela do instinto voltado para a destruição interna presente no ego, empregado para formar uma ligação erótica com o superego.

Os escritos de Freud abordados neste capitulo nos ajudam a pensar a dor enquanto seu caráter subjetivo. Compreender a singularidade da dor nas costas em pacientes portadores de hérnia de disco, identificar as possíveis razões psíquicas que estariam levando alguns pacientes a continuar com dor mesmo após a cirurgia e a outros pacientes a insistirem para ser operados, sem ao menos se submeterem aos procedimentos médicos considerados eficientes para o tratamento da dor lombar em função da hérnia de disco. São uma possibilidade de se reduzir o número exagerado de cirurgias de coluna, na medida em que essas atitudes dos pacientes parecem refletir necessidades da ordem do intrapsíquico.

Poder-se-ia considerar que alguns pacientes apresentam dor crônica lombar por se recusarem a amar, concentrando a libido em si próprios. Outros por estabelecerem relações objetais insatisfatórias, podendo inclusive acreditar que não lhes cabe outra 
possibilidade de escolha anaclítica. Alguns pacientes por submeter seus egos à rigidez do superego possibilitando o desenvolvimento do caráter masoquista que a serviço da pulsão de morte dita-lhes sofrimento intenso. Temos ainda alguns outros que se atormentam pela necessidade de punição, fruto da dificuldade de direcionarem a agressividade para o mundo externo. Enfim, falamos da dor crônica sob a ótica dos fatores intrapsíquicos, e a análise do material clínico apresentado mais adiante evidenciará como esses aspectos se apresentam no discurso e na produção gráfica dos pacientes que compõem a amostra desta tese. 


\section{O Psicodiagnóstico}

\section{a) Caracterização do Processo de Psicodiagnóstico}

A atividade diagnóstica é uma das atribuições da Psicologia clínica, cujo termo foi usado pela primeira vez em 1896, relacionado a instrumentos diagnósticos tendo como objetivo diferenciar doenças físicas das mentais que acometiam a população infantil.

Além da atividade diagnóstica, a Psicologia Clínica se voltava para a prevenção e para o alívio do sofrimento psíquico; o que solicitava constantes observações e estudos sobre as doenças mentais. A ênfase no estudo da compreensão dos processos psicológicos facilitou o desenvolvimento da Psicopatologia, ramo da Ciência destinado ao estudo do comportamento anormal. Vários trabalhos para diferenciar as alterações orgânicas endógenas, exógenas e desordens funcionais foram feitos dentro da área da Psicopatologia.

Em 1896, as áreas da Neurologia e Bioquímica eram as que mais trabalhavam na compreensão das relações de causalidade entre os distúrbios orgânicos e os distúrbios psicológicos.

No século XXI, a Neurocirugia e a seção de Psicologia do HSPE estão muito interessadas em compreender os aspectos psíquicos dos pacientes que sofrem de dor nas costas devido à hérnia de disco.

Utilizar-nos-emos do Psicodiagnóstico como um recurso auxiliar na obtenção dos dados, oferecendo às pacientes duas vias de expressão do material intrapsíquico: entrevistas e o teste projetivo H.T.P. (House, Tree, Person).

Dois séculos se passaram e marcaram diferenças na forma de se trabalhar com o Psicodiagnóstico. No começo do século passado, o interesse na realização da avaliação psicológica era com relação aos testes. Acreditava-se que apenas o instrumental psicométrico oferecia informações essenciais e fundamentais sobre a personalidade. 
Dentro dessa visão, a pessoa do psicólogo só tinha importância na medida em que aplicava, avaliava e analisava os protocolos dos testes.

No momento atual, a forma de se trabalhar com o Psicodiagnóstico é bastante diferente, uma vez que, aos testes, sobretudo à bateria psicométrica projetiva, adicionou-se a técnica da associação livre, a transferência e contratransferência originadas na Psicanálise, que delinearam uma identidade mais definida ao psicólogo.

Assim sendo, os testes oferecem auxílio na complementação e na articulação de informações, oferecendo ao paciente mais um recurso para a expressão dos aspectos intrapsíquicos. A influência da Psicanálise mobilizou alteração tanto na estrutura quanto na metodologia do Psicodiagnóstico.

Quando nos referimos à estrutura do Psicodiagnóstico, falamos de sua definição, objetivos e abordagem teórica que o fundamenta. Ocampo (1969, p.18) define Psicodiagnóstico como sendo:

Uma situação bipessoal, de duração limitada, cujo objetivo é realizar uma descrição e compreensão a mais profunda e completa da personalidade do paciente. Considera os aspectos passados, presentes e futuros da personalidade, utilizando para atingir tais objetivos entrevistas e técnicas projetivas.

Em se tratando de relação bipessoal, o psicólogo aparece como aquele que interage, empatiza-se e oferece-se como tela de projeção do paciente; condutas diferentes daquela época em que só se aplicava teste.

Assim sendo, os sentimentos e emoções do psicólogo motivados pelo setting terapêutico se constituem fatores significativos para o esclarecimento da subjetividade do paciente.

Os objetivos se voltam para a avaliação da estrutura e do dinamismo da personalidade considerando os fatores biológicos, os processos intrapsíquicos e as relações sociais do ser humano. A integração desses objetos possibilita hipóteses diagnósticas orientadoras de condutas terapêuticas.

A avaliação da personalidade exige estudos minuciosos, criteriosos e profundos. A Psicanálise, preocupada com a decifração do inconsciente, desponta como a abordagem teórica que oferece maior possibilidade desse objetivo ser alcançado, possibilitando a compreensão da origem dos conflitos, favorecendo senão a eliminação dos sintomas, com certeza a sua diminuição. 
O referencial teórico psicanalítico determina que o Psicodiagnóstico seja do tipo compreensivo, onde a relevância dos aspectos inconscientes é indispensável no entendimento da subjetividade do paciente.

Segundo Trinca (1984), os fatores que estruturam o Psicodiagnóstico, como processo compreensivo, são: ênfase na dinâmica emocional inconsciente; busca de compreensão psicológica globalizada; seleção de aspectos centrais; predomínio do raciocínio clínico; e prevalência do uso de métodos e técnicas de exame fundamentado na associação livre.

Quando se trabalha com Psicodiagnóstico compreensivo nos interessa compreender as causas dos sintomas apresentados pelo paciente entender quais os mecanismos inconscientes responsáveis pela manutenção da sintomatologia.

O psicólogo, por meio do Psicodiagnóstico compreensivo, tenta elucidar os aspectos inconscientes responsáveis pelos sintomas apresentados pelo paciente, mediante estudo minucioso e profundo da sua personalidade.

Assim sendo, para que esse objetivo seja alcançado é imprescindível que o psicólogo conheça e domine a técnica psicanalítica, para que pelo manejo da transferência e contratransferência possa decifrar as mensagens inconscientes expressas nas sessões de Psicodiagnóstico. Cabe ainda ao psicólogo que pretende realizar o Psicodiagnóstico ter experiência na aplicação, avaliação e interpretação do instrumento psicométrico que está utilizando.

O diagnóstico compreensivo propõe extensa coleta de informações abrangendo o meio familiar, profissional e social do paciente, bem como os vários aspectos de sua personalidade e a interrelação desses com os primeiros.

A hipótese diagnóstica é formulada mediante a apreciação do maior número possível de informações obtidas ao longo do processo de psicodiagnóstico. Diante do material clínico coletado no processo de psicodiagnóstico, o psicólogo seleciona os dados que são relevantes para o entendimento da problemática emocional. A relevância de determinado dado se faz em função de sua relação com as angústias e fantasias constituintes de um processo patológico. No entanto, é sempre importante salientar que a personalidade se movimenta constantemente, e o que é angustiante hoje em outro momento já não representa sofrimento.

A metodologia do Psicodiagnóstico nos orienta quanto às técnicas utilizadas para alcançarmos os objetivos propostos em uma avaliação psicológica. As 
entrevistas e bateria psicométrica são os procedimentos metodológicos utilizados no Psicodiagnóstico.

\section{b) As Entrevistas no Processo de Psicodiagnóstico}

De modo geral, entrevista é o encontro de uma ou de mais pessoas em um local e horário para abordar determinado assunto. Quando se trata de entrevista psicológica existe um pedido de ajuda, sinalizando que, algo no campo emocional está trazendo sofrimento àquele que solicita. As entrevistas do Psicodiagnóstico são: inicial, subseqüentes e devolutiva.

$\mathrm{Na}$ entrevista inicial conhecemos a queixa trazida pelo paciente que é denominada de queixa manifesta. A segunda tarefa da entrevista inicial é a pesquisa dessa queixa, caracterizada por questões que visam obter mais informações sobre: o início da problemática, sua duração, possíveis causas da sintomatologia atribuídas pelo paciente, enfim perguntas que elucidem ao psicólogo a razão do pedido de ajuda. A informação do enquadre é a terceira tarefa da entrevista inicial e garante que algumas variáveis que influenciem no processo se mantenham constantes. O esclarecimento dos papéis de cada componente envolvidos, a determinação do local, honorários, horário e duração do processo são os aspectos que devem ser mantidos sempre constantes.

Nas entrevistas subseqüentes utilizamos a anamnese, para obter informações mais detalhadas sobre a história de vida do paciente, sobre o seu cotidiano, suas relações familiares, sociais, sobre suas perspectivas futuras, suas preferências sexuais, avaliando a relação dessas comunicações com as queixas manifestas, conhecidas na entrevista inicial.

A entrevista devolutiva é a entrevista onde comunicamos ao paciente a conclusão do processo de Psicodiagnóstico.

A compreensão dos motivos latentes implícitos no sofrimento, o esclarecimento da relação existente entre a sintomatologia atual e experiências anteriormente vividas, fortalecem o compromisso do paciente com a conduta terapêutica que está sendo proposta, garantindo-se maior êxito na sua aceitação, diminuindo o êxodo dos tratamentos. 
Trabalharemos com o modelo de Psicodiagnóstico proposto por Ocampo e Arzeno, no atendimento aos pacientes encaminhados pela Neurocirurgia. Desse modo, a realização do Psicodiagnóstico, volta-se para a obtenção de um maior número possível de informações sobre o paciente visando esclarecê-lo por apontamentos e/ou interpretações dos conteúdos emocionais detectados ao longo do processo de Psicodiagnóstico.

A maioria das pacientes com dor nas costas, em função da hérnia de disco, encaminhados da Neurocirurgia, chega à seção de Psicologia por que insistem em fazer a cirurgia acreditando ser essa a única conduta que se não terminar com a dor pelo menos irá aliviá-la. No início, sua concepção é a de que a dor nas costas é única e exclusivamente em virtude da hérnia de disco; portanto, é só operar que a dor irá passar. Esse comportamento nos faz pensar num primeiro momento que os aspectos emocionais estariam banidos da vida dessas pacientes.

No entanto, o que temos observado nas entrevistas psicológica é que elas falam sobre: decepções no casamento, no relacionamento com os filhos, dificuldades financeiras, fracassos profissionais, lutos não aceitos como participantes importantes na analgesia; dor essa que não é tratada com analgésicos, mas sim pelo atendimento psicológico.

Assim sendo, comportam-se de um jeito na consulta médica e de outro na entrevista psicológica o que nos faz supor que elas respondem de acordo com a forma como são abordados pelo profissional: o médico se interessa pelo físico, o psicólogo pelo emocional.

A integração do físico com o psicológico é sem dúvida muito importante e quando se trata de um contexto hospitalar essa união assume caráter inclusive de evitar conduta mais invasivas ao paciente. A sensibilidade do médico para os aspectos psicológicos proporciona o encaminhamento do paciente à Psicologia, dando-lhe assim a oportunidade de contato com os elementos psíquicos que também influem no sintoma que aparentemente poderia ser apenas da ordem do físico.

A participação da paciente no Psicodiagnóstico pode ser uma das maneiras de iniciação ao contato com as questões subjetivas, tão presentes em suas vidas e ao mesmo tempo tão desconsideradas.

O fato de falarem sobre outros assuntos, além da dor, e principalmente associar essas outras questões como possíveis responsáveis pela dor, desperta a 
condição de se apropriarem da influência dos fatores psíquicos em suas vidas, motivando-os para o tratamento psicoterápico.

O esclarecimento à paciente sobre a sua passividade intensa frente a uma frustração sobre o descontrole das emoções causando comprometimento na sua adaptação à rotina familiar, social ou profissional, a inferioridade fazendo com que se perceba como incapaz são alguns dos aspectos psicológicos que podem contribuir para a manutenção da dor.

\section{c) Os Testes Projetivos Gráficos}

Dentre os testes de personalidade, as técnicas projetivas ocupam um lugar de destaque pela sua condição de avaliar de modo amplo e global as características psicológicas do ser humano.

A essência das técnicas projetivas se situa na apresentação de tarefas não estruturadas, relacionadas a estímulos vagos ou ambíguos, seguidos de instruções breves.

O objetivo das técnicas projetivas é compreender a estrutura e o dinamismo da personalidade, uma vez que trabalhando com estímulos ambíguos, a maneira como a pessoa os organiza refletirá seus aspectos emocionais, vocacionais, interpessoais e intelectuais.

Os desenhos projetivos encontram lugar seguro na bateria psicométrica, em função da facilidade de aplicação, economia de tempo, sobretudo pela importância da informação clínica. Tais características fizeram-no instrumento projetivo de uso diário na Psicologia.

Os primeiros estudiosos nesse campo foram Buck (1947), Paul Schilder (1950), Laureta Bender (1952) e Karen Machover (1953). Graças aos seus trabalhos os psicólogos puderam conhecer os primeiros conceitos sobre imagem corporal, o que motivou um maior interesse sobre a utilização de desenhos enquanto instrumentos projetivos.

Lourenção van Kolck, citada por Trinca (1972, p.6) divide as técnicas gráficas em quatro grupos: 1 . cópias de determinados motivos com modelos completos a serem reproduzidos; 2. complemento de desenhos, linhas ou pontos; 3. realizações 
gráficas sobre um tema proposto ou desenhos temáticos sem modelo; 4. desenhos livres.

O presente estudo trabalhará com as técnicas que se enquadram no terceiro grupo de classificação proposto por Kolck. Assim sendo, apenas mencionaremos as técnicas pertencentes aos outros grupos. O teste de Completar figuras de Wartegg, citado por Trinca (1972, p.8), foi elaborado entre 1920 e 1930, destinado a crianças, adolescentes e adultos de ambos os sexos, e sua análise propicia a compreensão das necessidades e tensões dos examinandos.

O Desenhos em Oito Folhas de Caligor, citado por Trinca (1972, p.8), solicita a realização de uma série de oito desenhos da figura humana, cada um dos quais baseado no anterior. O autor do teste objetivou que o instrumento avaliasse traços paranóicos, papéis masculino-feminino e auxiliasse no diagnóstico diferencial de psicótico e indivíduos considerados normais.

Os testes como Desenho da Casa, de Minkowska(1947); Teste D - 10, de Le Men (1953); Teste de Complementação de Desenhos, de Franck (1966); Teste de Prudhommeau (1947); Teste do Desenho de uma Moça sob a Chuva (1934), aparecem na literatura como sendo os menos utilizados na prática da psicologia, todos citados por Trinca (1972, p.9)

Historicamente, o homem utilizou desenhos para registrar seus sentimentos e ações. Desde o homem das cavernas até o civilizado expressaram suas emoções, interesses e necessidades em trabalhos artísticos. A comunicação gráfica aparece muito cedo na vida humana: a criança desenha primeiro e depois fala. Nos desenhos assim como nos sonhos os conflitos inconscientes são manifestos pela linguagem simbólica.

Os aspectos da dinâmica da personalidade que surgem nos desenhos projetivos foram descobertos mediante as seguintes vias: informação sobre o examinando, associação livre, compreensão de símbolos e comparação entre desenhos de uma mesma série ou entre desenhos e informações do Rorschach e do T.A .T.

O campo da interpretação dos desenhos projetivos se baseia nos seguintes pontos: 1. na utilização dos significados simbólicos, comuns na Psicanálise e no folclore, derivados de estudos que os clínicos têm realizado sobre sonhos, arte, mitos e outras atividades impregnadas de determinismo inconsciente; 2. experiência clínica com os mecanismos de deslocamento e substituição. Assim como uma ampla gama 
de fenômenos patológicos, em especial sintomas de conversão, obsessão e compulsão, fobias e estados psicóticos, os que só podem ser compreendidos pela interpretação simbólica; 3. a compreensão do simbolismo mediante a associação do paciente; 4. a correlação entre os desenhos projetivos realizados em intervalos durante o curso de uma terapia e o quadro clínico nos momentos em que os desenhos são feitos.

Karen Machover, citada por Trinca (1972, p.13), usou o desenho de uma pessoa não mais como teste de inteligência, mas unicamente como prova projetiva. A idéia básica da interpretação é a de considerar o desenho como expressão corporal.

Koppitz, citada por Trinca (1972, p.14), também utilizou desenhos da figura humana com crianças e adolescentes, e padronizou dois sistemas de pontuação objetiva. O primeiro deles baseado no Goodenough-Haris Drawing Test e na experiência clínica de Koppitz, considera os desenhos da figura humana como teste de desenvolvimento mental. O segundo, originado no trabalho de Machover é um teste projetivo das atitudes interpessoais e preocupações das crianças.

O teste de Desenho do Interior do Corpo (Inside of the Body Test), criado pelos americanos C. B. Tait e R. L. Ascher, em 1955, foi inicialmente aplicado em pacientes cardíacos ou em diálise renal (Anzieu, 1984, p.210).

Os autores consideravam que as forças psíquicas determinantes do desenho de certo órgão são as mesmas que produzem os sintomas psicossomáticos de todas as doenças, e esse instrumento permite reconhecimento mais rápido de distúrbios psicopatológicos, do que o exame médico.

O Teste da Árvore teve vários precursores: Emile Jucker, desde 1928, pedia aos seus orientandos para desenharem árvore e depois avaliava essa produção gráfica empiricamente. Schliebe, em 1934, estudava a expressão de afetos em vários desenhos sucessivos de árvores: uma árvore qualquer, depois uma gelada, uma alegre, uma pedindo auxílio, uma sofrendo e uma morta (Anzieu, 1984, p.210).

Em 1947, nos Estados Unidos, Buck cria o Teste H.T.P. (Casa, Árvore, Pessoa), associando o desenho da árvore com os da casa e da figura humana. As características dos desenhos, juntamente com uma ampla investigação constituem fonte de hipóteses sobre áreas gerais de conflito (Anzieu, 1984, p.210). 
Precker (1950), citado por Trinca (1972, p.15), analisando o uso da técnica de desenhos livres, concluiu que ela realmente possui valor preventivo e de higiene mental, fornecendo elementos para a compreensão do Psicodiagnóstico de Rorschach, permitindo, ainda, a avaliação das alterações no desenvolvimento tanto em situações de vida quanto no curso de tratamentos, apresentando-se como instrumento de importância no prognóstico clínico.

Segundo E. Stern (1967), citado por Trinca (1972, p.5), a utilização das técnicas projetivas está a serviço da psicologia clínica. Considera que: “Quando um sujeito não pode se expressar verbalmente seja por pouca idade, no caso de crianças, porque sofre de algumas inibições ou dificuldades, seja porque, devido a qualquer outra razão, a expressão gráfica satisfaz muito mais do que a verbal”.

No entanto há controvérsias quanto à utilização das técnicas gráficas. Bernstein (1969), citado por Trinca (1972, p.5), assinala que:

O instrumento por excelência na clínica psicológica, é a entrevista; os testes projetivos estão a serviço da entrevista, visto que, a rigor, são apenas dispositivos para conduzir uma forma especial de entrevista. Trata-se pois, certamente, de uma variedade experimental de entrevista que mobiliza, dirige e controla, especialmente a projeção do sujeito.

Segundo Levy (1959), citado por Trinca (1972, p.10):

O desenho pode ser uma projeção de auto conceito, uma projeção de atitudes para com alguém do ambiente, uma projeção da imagem ideal do eu, um resultado de circunstâncias, uma expressão de padrões de hábitos, uma expressão da tonalidade emocional, uma projeção de atitudes do sujeito para com o examinador e a situação, uma expressão de suas atitudes para com a vida e a sociedade em geral. É usualmente uma combinação de tudo isso. Além do mais, o desenho pode era uma expressão consciente ou pode incluir símbolos profundamente disfarçados, expressivos de fenômenos inconscientes.

Stern (1961), citado por Trinca (1972, p.10) considera que os desenhos:

São um meio de contato entre doente e psicoterapeuta, tendo um valor funcional e substituindo temporariamente a linguagem oral. O desenho e a pintura podem servir como meios de investigação e, daí, como testes. É possível, comparando o desenho de determinada criança com as normas conhecidas de desenvolvimento, avaliar a sua evolução.

Anzieu, citado por Trinca (1972, p.6), considera que o desenho de uma criança se constitui em um dos melhores meios para se avaliar o desenvolvimento da sua percepção, seu mundo mental e a sua personalidade. 
Segundo Elkisch (1966), citado por Trinca (1972, p.6), desenhos livres são “movimentos expressivos que um indivíduo projeta inadvertidamente através de meios gráficos (lápis ou pintura) em folha de papel ou tela”.

São inúmeros os trabalhos relacionados ao desenho livre e desajuste da personalidade. Os mais conhecidos são os de Bender e Schilden (1969), sobre jovens delinqüentes; de Deabacova (1967), sobre indicadores de ansiedade em crianças; de Lapkin e colab. (1968), sobre processos esquizofrênicos em adolescentes; de Chalhons (1967), sobre traços normais e anormais em adolescentes; de Kreici (1969), sobre o amadurecimento das relações mãe-criança ; de Nehlil e colab. (1968), sobre episódio delirante infantil.

Lourenção Vankolck e Angelini (1968) estudaram o desenho livre em crianças de grandes cidades do Brasil e Vankolck sistematizou os conhecimentos para interpretação psicológica de desenhos livres.

VanKolck (1968), citada por Trinca (1972, p.14), considera três processos fundamentais para a avaliação de desenhos livres:

1. Adaptativo, que consiste em verificar se o produto corresponde ao que se espera da idade e do ambiente cultural do sujeito e, no caso de um desenho solicitado, se o produto e a maneira como foi executado atendem ao que foi proposto; 2. Expressivo, que diz respeito ao estilo particular da resposta de um indivíduo; 3. Projetivo que é aquele em que o indivíduo atribui as próprias necessidades e qualidades a situações e objetos externos ou a outras pessoas, sem que disto tenha consciência.

Hammer (1969) assinala:

No trabalho artístico de um certo número de indivíduos, observamos que as pessoas tendem a expressar em seus desenhos, as vezes de forma bastante inconsciente, uma visão de si mesmos tal como são ou tal como gostariam de ser. Os desenhos representam uma forma de linguagem simbólica que mobiliza níveis relativamente primitivos da personalidade. (p.46).

O procedimento de Desenhos-Estórias de Walter Trinca, elaborado em 1972, tem sido muito utilizado tanto em pesquisa quanto na prática clínica. Solicita-se ao examinando que desenhe uma série de cinco desenhos livres (cromáticos ou acromáticos) cada qual sendo estímulo para que conte uma estória associada livremente logo após a realização de cada desenho. Tendo concluído cada desenhoestória, o examinando segue fornecendo esclarecimentos (fase de inquérito) e o título da estória. Os desenhos livres se tornam, assim, estímulos de apercepção temática. 


\section{O Teste Projetivo H.T.P. (House, Tree, Person)}

A constatação de Hammer, “Os músculos das pessoas são honestos” (1969, p. 51), denúncia o que os músculos do rosto, dos ombros, enfim, o esquema corporal como um todo, fazem quando tentamos ocultar algo pela linguagem oral. Em sua concepção, "o verdadeiro uso da linguagem não consiste tanto em expressar nossas necessidades, mas também em ocultá-las” (1969, p. 51).

Nesse sentido, nossa expressão motora parece ser mais eloqüente do que a oral; baseando-se nessa premissa os desenhos projetivos, quando utilizados em um processo de Psicodiagnóstico facilitam a expressão dos conflitos, dos traumas, das situações mais angustiantes para as pessoas, que as vezes demorariam muito para aparecerem nas sessões de análise.

O teste projetivo H.T.P. (Casa, Árvore, Pessoa) foi criado por John N. Buck, nos Estados Unidos, em 1947. A justificativa do autor para ter escolhido essa temática se fez em função de:

1. os temas serem familiares a todos,

2. são conceitos desenhados por indivíduos de todas as idades, o que os torna mais aceitáveis do que outros,

3. estimulam uma verbalização mais espontânea que outros temas

A aplicação do teste H.T.P. consiste em pedir para que o paciente faça um desenho de uma casa, de uma árvore e de uma pessoa, sendo cada desenho em uma folha de papel, e após a produção gráfica, há o inquérito de cada desenho.

O material utilizado na aplicação consiste de: folhas de papel lápis preto $\mathrm{n}^{\circ} .2$, lápis de cor e borracha .

Hammer (1969) menciona que os desenhos da Casa, Árvore e Pessoa evidenciam a imagem interna que o paciente tem de si e do seu ambiente. A Casa, sendo o lugar onde se mora, provoca associações sobre as relações familiares e 
sociais. Por exemplo, se o paciente é uma criança, ao desenhar a casa expõe qual é o seu lugar nos envolvimentos com seus pais e irmãos. Quando o paciente é casado, manifesta pelo desenho da casa, a situação doméstica com o cônjuge.

De acordo com Hammer (1969), o desenho da Árvore permite a projeção de sentimentos profundos da personalidade. A experiência clínica evidencia que é mais fácil projetar no desenho da árvore os conflitos mais perturbadores do que no desenho da pessoa, na medida em que o paciente sente-se mais protegido de não ser descoberto, não necessitando intensificar os mecanismos defensivos.

Desse modo, o desenho da pessoa, é o que é feito com maior freqüência de forma incompleta, pois esse grafismo se aproxima demais da própria pessoa. O desenho da pessoa pode motivar três tipos de temas: o auto-retrato, o ideal de ego e a representação de pessoas significativas para o paciente. No auto-retrato, o paciente revela o que sente ser. No ideal de ego, desenha o que deseja ser. Na representação de uma pessoa significativa para o paciente, geralmente as crianças e os adolescentes desenham as figuras parentais denotando a importância que os pais tem em suas vidas enquanto modelos de identificação.

Na medida em que a pessoa desenha, os conteúdos inconscientes se tornam manifestos, possibilitando ao psicólogo a compreensão das características de personalidade. A análise da subjetividade evidenciada na técnica projetiva H.T.P. permite classificar o paciente dentro dos quadros psicopatológicos, dando-nos um referencial quanto a melhor terapêutica a ser indicada ao paciente, visando o seu aproveitamento e aderência ao tratamento.

Segundo Hammer (1969), a interpretação dos desenhos se baseia nos seguintes pontos:

1. no uso dos significados simbólicos comuns na psicanálise, derivados dos estudos sobre sonhos, mitos, arte, fantasia e outras atividades semelhantes impregnadas de determinismo inconsciente.

2. na experiência clínica com os mecanismos de deslocamento, assim como com a ampla gama de fenômenos patológicos, especialmente sintomas conversivos, obsessivos, compulsivos, fóbicos, os estados psicóticos, que apenas são possíveis de serem compreendidos através da leitura simbólica.

3. A decifração da simbolização usada nos desenhos, mediante a associação do paciente. 
4. A evidencia empírica derivada dos desenhos prévios dos pacientes.

5. A correlação entre os desenhos projetivos realizados em intervalos durante a terapia e o quadro clínico nos momentos em que realiza o desenho.

6. A coerência interna entre um desenho e o outro, entre os desenhos e outras técnicas pertencentes à bateria psicométrica, entre os desenhos e os sonhos. Entre os desenhos e o comportamento e entre os desenhos e a historia de vida (p.46).

A avaliação e a interpretação do teste projetivo H.T.P. (House, Tree, Person) devem ser feitas com critérios sendo importante um roteiro para que possamos levantar os pontos principais do desenho bem como o seu significado.

Hammer (1969) propõe que a análise do H.T.P. seja feita considerando-se os aspectos expressivos e os aspectos de conteúdo dos desenhos.

Os aspectos expressivos transmitem matizes diferentes de significado e de acordo com Allport e Vernon, citados por Hammer (1969, p.52) ${ }^{10}$ "vale la pena extraer, refinar y forjar, el rico mineral de los movimientos expressivos, pues dichos movimientos constituyen la 'escritura cerebral'”.

Os aspectos expressivos, de acordo com Hammer (1969), são representados pela seqüência com que os desenhos são realizados. O tamanho do desenho, bem como a pressão do lápis durante a sua execução constituem-se elementos dos aspectos expressivos. A qualidade do traçado, a preocupação com detalhes, com a simetria do desenho e com a configuração de movimentos são também componentes dos aspectos expressivos.

A interpretação refere-se a cada um dos aspectos expressivos, acrescido da observação que se faz do paciente durante a aplicação do H.T.P.

Retondo (2000), no Manual Prático de Avaliação do H.T.P. (Casa, Árvore, Pessoa) e Família, organiza de modo bastante didático os aspectos expressivos, propostos por Hammer, evidenciando ainda o significado de algumas doenças que mais tiveram suas características detectadas nesse teste projetivo.

Na medida em que o H.T.P., segundo Retondo, é uma técnica projetiva que visa "penetrar na personalidade individual" (2000, p.159), contribuindo para a investigação das características estruturais da personalidade e atribuindo um sentido ao desenho que é projetado em uma folha de papel, entendemos tratar-se de um

${ }^{10}$ Allport, G. W. e Vernon, P. E., Studies in Movement, Nova York, Macmillan, 1933. 
instrumento de significativa importância na compreensão da subjetividade da dor, auxiliando-nos na orientação da conduta terapêutica aos pacientes que sofrem de dor lombar em virtude de hérnia de disco. 


\section{Método}

O trabalho ora apresentado se trata de uma pesquisa clinica. A pesquisa clínica engloba os procedimentos clínicos de um lado e o processo de produção de conhecimentos válidos e comunicáveis da pesquisa de outro. Giami (1993) aponta ser necessário distinguir a pesquisa em Psicologia Clínica da pesquisa clínica.

Na pesquisa em Psicologia Clínica, a produção de conhecimentos é o objetivo principal do pesquisador. Mesmo sendo clínico essa posição não interfere no processo de pesquisa. Não é elaboração de conhecimento específico a partir da experiência prática, mas a tomada das práticas, com seus processos e efeitos como objeto de estudo, a fim de aperfeiçoá-las ou transformá-las a partir dos resultados da pesquisa. O pesquisador se coloca externamente às situações estudadas e se utiliza de referenciais teóricos e metodológicos diferentes dos terapeutas.

Segundo Huler (1987), citado por Giami (1993, p.2), a pesquisa em Psicologia visa a dois fins:

A observação, a descrição e a explicação de fenômenos e processos encontrados em psicologia clínica em geral, a elaboração e a aquisição de um saber teórico. [...] e a elaboração e a validação dos meios de ação que ela procura em seguida melhorar ou substituir por novas técnicas.

A pesquisa clínica atribui peso e valor à intervenção e a prática clínica e ao processo de produção de conhecimentos. O conhecimento cientifico emerge inicialmente por meio da intervenção e, colocado no centro da mesma, constitui-se em um momento de um procedimento que busca uma resposta a demanda do paciente. É uma visão de ajuda que norteia a intenção de saber e compreender.

De acordo com os autores Lagache (1962), Talvez-Boutonier (1962) e Bourguignon (1986) citados por Giami, (1993, p.2) o objetivo da pesquisa clínica reside respectivamente:

“No estudo de uma personalidade singular na totalidade de sua evolução e da sua situação”. 
“Ou ainda na singularidade ou totalidade de um sujeito, levando em conta simultaneamente seu funcionamento psíquico sua maneira de relacionar-se, a história vivida, os acontecimentos exteriores”.

"Esse objetivo surge inicialmente como carregado de uma imensidão dificilmente conciliável com as exigências inerentes a todo o processo de pesquisa científica”.

A redução e a necessidade para o pesquisador de dispor de situações provocadas e construídas são exigências principais. A redução implica um direcionamento escolhido da realidade; a um objetivo restrito; a conceitos operatórios; a hipóteses de trabalho; a uma variável e controle das outras. E, as situações provocadas chocam-se com situações reais de envolvimento de indivíduos, de tipo terapêutico - individual ou coletivo - nas quais o clínico responde a uma demanda.

A prática de pesquisa clínica, como a de toda pesquisa, é constituída por diferentes momentos:

A pesquisa clínica resulta da autonomia relativa da prática de conhecimento em relação aos objetivos terapêuticos ou de mudanças. Ela se apóia sobre situações (terapêuticas ou não terapêuticas) que podem dar lugar a efeitos clínicos de mudança, assim como de resistência a esses efeitos ( Giami,1993, p.3).

Nesse sentido, as situações terapêuticas assim como as situações de pesquisa ou provocadas pelo pesquisador, são vistas como recolhimento de material. Material esse, integrado em diferentes processos desenvolvidos a partir dele, retomados expostos em documentação elaborada. A pesquisa clínica necessita da construção e articulação de dois tipos de metodologia:

De um lado. metodologias e estratégias de pesquisa que constituem o quadro de validação da pesquisa clínica e permitem resgatar significações entre o pesquisador e os agentes, enquanto significações de discursos produzidos por agentes ( recolhimento e tratamento). De outro lado, metodologias de intervenção, que visam levar em conta as demandas implícitas de sujeitos e a gerar as situações em que são evidenciadas técnicas como a condução da entrevista, a dinâmica de grupo, os testes etc., surgem no interior do dispositivo da pesquisa. (Giami,1993, p.3).

O psicodiagnóstico de três pacientes do sexo feminino foi o objeto da presente pesquisa clínica, realizada nesse trabalho.

É importante ressaltar que houve um hiato entre a solicitação da Neurocirurgia para o atendimento dos pacientes com hérnia de disco que insistiam em serem 
submetidos a outra cirurgia bem como daqueles que se negavam a fazer outro procedimento que não fosse o cirúrgico, e o interesse da pesquisadora em torna esse estudo tema da sua tese de doutorado.

Desse modo, o material clínico apresentado neste estudo foi retirado tanto das pastas que contém as entrevistas e os desenhos do H.T.P. que ficam arquivadas na seção de Psicologia, bem como dos prontuários dos pacientes, razão pela qual utilizamos o termo de consentimento informado, encaminhado ao Comitê de Ética do Hospital do Servidor Público do Estado de São Paulo. (Conforme modelo na p.51)

Nesse estudo, como em toda pesquisa cientifica, a fase inicial levou a construção de um corpo de hipóteses a partir de questões que se colocam ao pesquisador. Assim, o psicodiagnóstico foi o aspecto selecionado para ser analisado, em busca de uma resposta ao problema.

Essa hipótese foi, então, confrontada à teoria, em um momento reflexivo, na tentativa de traduzir questões oriundas da prática clinica em linguagem conceitual de pesquisa.

O olhar clínico da pesquisadora se limitou a levar em conta os aspectos observáveis e significativos, em resposta ao referencial teórico, conforme aponta Harrison-Covello et al ( 1984), citado por Giami (1993). A análise do material tornou possível transformar em pesquisa clínica os casos atendidos no setor de Psicologia do HSPE.

Baseando-nos no exposto, e na forma como trabalhamos para obter o material clinico bem como a maneira como efetuamos sua análise, acreditamos que realizamos uma pesquisa tanto em Psicologia Clínica como uma pesquisa clínica com o objetivo de estudar a hipótese de que o Psicodiagnóstico, constituído por entrevistas psicológicas e o teste projetivo H.T.P. é um instrumento importante para detectar o dinamismo psíquico, possibilitando a compreensão da subjetividade da dor em pacientes portadoras de hérnia de disco.

A possibilidade de contribuirmos para o encaminhamento mais adequado às necessidades das pacientes e colaborarmos para uma provável diminuição do número de cirurgias de coluna, nos entusiasma e nos mobiliza a realizar este trabalho, que, pela sua utilidade, justifica-se como estudo condizente a uma tese de doutorado.

Objetivos:

1. Geral: 
Analisar os aspectos psicológicos da dor em paciente portadoras de hérnia de disco.

\section{Específicos:}

a. Por meio do Psicodiagnóstico, investigar a correlação da permanência da dor em pacientes portadoras de hérnia de disco, que já foram submetidas à cirurgia.

b. Por meio do Psicodiagnóstico, investigar as razões pelas quais as pacientes insistem em fazer a cirurgia de hérnia de disco, mesmo não tendo indicação para tal conduta, em função do tamanho pequeno da hérnia de disco.

c. Amostra

A amostra se constituiu de três pacientes do sexo feminino, com as seguintes idade: 58, 53 e 50 anos, sendo duas viúvas e uma separada, com as seguintes profissões: metalúrgica, cozinheira e ajudante de pesquisa. As pacientes se queixavam de dor nas costas, devido à hérnia de disco após terem sido submetidos à cirurgia e, ou estarem fazendo tratamentos medicamentoso e fisioterápico.

Todas as pacientes foram submetidos à consulta médica, na qual foi realizado o exame físico. A ressonância magnética foi feita em todas as pacientes que compõem a amostra.

Após esses procedimentos, as pacientes realizaram o Psicodiagnóstico.

Procedimento:

O Psicodiagnóstico consistiu de duas entrevistas: inicial e subseqüente, aplicação do teste projetivo gráfico H.T.P. (House, Tree, Person) e uma entrevista devolutiva.

As sessões do psicodiagnóstico foram realizadas semanalmente no consultório da seção de Psicologia do Hospital do Servidor Público do Estado de São Paulo, em sessões de 50 minutos.

As entrevistas realizadas foram transcritas e para a aplicação do H.T.P. se utilizou papel sulfite, lápis grafite número 2, borracha e lápis de cor. Após cada desenho foi solicitado que o paciente contasse uma história relacionada ao desenho que havia feito.

A história relacionada com o desenho diferencia-se da orientação original do teste que solicita após os desenhos a realização do inquérito com questões préestabelecidas. O recurso história após o desenho favorece os aspectos projetivos com menor possibilidade de indução. 
Os atendimentos foram realizados por duas aprimorandas do curso de Psicologia Clinica mantido pela Fundação de Desenvolvimento Administrativo FUNDAP, no Hospital do Servidor Público do Estado de São Paulo, onde a pesquisadora exerce a função de coordenadora da seção de Psicologia do Serviço de Psiquiatria e Psicologia Médica, assim o psicodiagnóstico foi supervisionado pela pesquisadora. 


\section{AO COMITÊ DE ÉTICA DO HSPE}

Tema da Tese de Doutorado: Psicodiagnóstico: Compreensão dos Aspectos Psíquicos da Dor em Portadoras de Hérnia de Disco.

Kátia da Silva Wanderley

Psicóloga da seção de Psicologia do Serviço de Psiquiatria e Psicologia Médica.

\section{TERMO DE CONSENTIMENTO INFORMADO}

Venho por meio desta informar que o material utilizado na minha tese de doutorado foi retirado exclusivamente dos registros dos prontuários e pastas arquivadas na seção de Psicologia, dos pacientes atendidos no Ambulatório de Psiquiatria e Psicologia Médica.

Informo ainda, que não foi realizada qualquer tipo de intervenção com os respectivos pacientes, sendo que o material clínico foi composto de fragmentos das entrevistas devidamente registradas nos arquivos citados.

Os referidos nomes são fictícios e as informações que pudessem acarretar na sua identificação foram ora omitidas ora alteradas, visando manter o sigilo e os devidos preceitos éticos que resguardam o paciente de eventuais dolos.

Sem mais, desde já me coloco à disposição para maiores esclarecimentos. 


\section{Análise dos Resultados}

O método psicanalítico se caracteriza pela associação livre, pela interpretação dos conteúdos inconscientes e a sua utilização nesse trabalho é uma tentativa de trazer a luz algumas das causas da perpetuação da dor lombar devido à hérnia de disco e possibilitar maior reflexão sobre a influência dos fatores psíquicos na constância do processo doloroso.

Não temos intenção de fazer um estudo estatístico dos dados obtidos no Psicodiagnóstico, mas, sim, estudo qualitativo.

Quando falamos em método psicanalítico é fundamental que recorramos a transferência enquanto meio de alcance à compreensão da subjetividade.

Para Meyer (1993, p.29),

A transferência colocada a serviço do método, ela dá ao conflito psíquico um caráter de atualidade tornando também transparente sua forma defensiva de expressão. Toda produção do paciente vai adquirir um sentido de transferência, criando um campo que "excede" as figuras do analista e do analisando, que o construíram e que neles estão inseridos. O material que o compõe procede de uma seleção que não é arbitraria: os critérios de escolha são justamente expressivos dos mecanismos - de origem e dinâmica - inconscientes, que contribuíram para formar e caracterizar o campo.

Conforme ressalta Safra (1993) quando se faz pesquisa tendo como modelo a psicanálise há necessidade que se integre a teoria com o material clinico obtido mediante as entrevistas realizadas com o paciente, visando com esse procedimento garantir o rigor medotológico.

No entanto, por mais cuidado que tenhamos para assegurar a qualidade metodológica algumas dificuldades são encontradas e, segundo Safra (1993, p.123), relacionam-se aos seguintes aspectos:

a. Exatidão do material apresentado

Seria o relato apresentado uma expressão acurada do que realmente se passou no consultório, uma vez que o analista não toma notas durante as sessões e que a descrição clínica é sempre construída a partir de sua memória? 
Como registrar por qualquer meio disponível as inúmeras associações realizadas, silenciosamente, pelo analista diante do comportamento e verbalizações do paciente?

Esta tese lança mais uma dificuldade relacionada à exatidão do material, na medida em que os dados clínicos foram obtidos por terceiros e supervisionados. Assim sendo, necessariamente temos que contar com a memória daquele que entrevistou, e também com o pensamento clínico desenvolvido pelo supervisor. Tais questões parecem configurar um terreno não propicio ao desenvolvimento de pesquisa. Porém na medida em que a prioridade da psicanálise é a participação do sujeito no fenômeno que observa; as condições utilizadas no procedimento dessa tese tornam possível a realização de um trabalho cientifico.

Segundo Safra (1993, p.129-130), outras dificuldades quanto à metodologia quando o modelo de pesquisa é o psicanalítico, referem-se aos seguintes fatores:

a. O recorte da pesquisa

A experiência clínica apresenta uma infinidade de variáveis e fenômeno impossíveis de serem abarcados por um único vértice ou concepção teórica.

Ao iniciarmos uma investigação a partir de um material clínico, realizamos um recorte, que é delimitado pelo aspecto ou fenômeno que estamos interessados em pesquisar, e também pelas concepções teóricas que utilizamos em nosso trabalho.

b. O psicanalista como pesquisador

Dentro do modelo psicanalítico, não se pode falar do estudo do fenômeno psíquico sem levar em conta também o psiquismo do pesquisador. Os objetos de investigação psicanalítica fazem parte também da vida psíquica do investigador. Esse fato tanto pode contribuir para elucidar os fenômenos observados na sessão quanto pode ocultá-los.

Assim sendo, há necessidade que o pesquisador submeta-se à análise própria bem como supervisione o material clinico coletado visando uma maior aproximação do seu objeto de estudo: o entendimento da subjetividade implícita no sintoma apresentado pela amostra estudada.

Nesta tese, as entrevistas foram analisadas segundo o referencial psicanalítico, baseando-se na teoria freudiana, e o teste projetivo H.T.P. (House, Tree, Person) foi avaliado e interpretado mediante os pressupostos propostos por Emanuel F. Hammer (1969) e Maria Florentina Godinho Retondo (2000). 


\section{Material Clínico}

O material clínico obtido no Psicodiagnóstico será apresentado por meio das entrevistas com a paciente e dos desenhos que caracterizam o teste projetivo H.T.P., seguidos de suas associações.

\section{Sujeito 1}

Paciente: Martha (nome fictício), 58 anos, metalúrgica aposentada, viúva, tem duas filhas sendo uma adotiva.

História da hérnia de disco:

A paciente foi operada pela primeira vez em 1990 quando foi diagnosticada hérnia de disco através do exame físico e da ressonância magnética. Em 1992, fez outra cirurgia, pois sentia muitas dores nas costas sendo novamente operada. No inicio de 2001 voltou a sentir dores nas costas procurou a clínica de Neurocirurgia, solicitando nova intervenção cirúrgica, porém o médico disse que o seu problema era emocional e que por essa razão, dessa vez, não seria operada.

\section{PRIMEIRA ENTREVISTA PSICOLÓGICA}

Psicóloga: Qual o motivo do médico encaminhar a senhora para a Psicologia?

Paciente: Eu já operei duas vezes a coluna devido à hérnia de disco, agora o médico disse que não seria operada, pois o meu problema no momento é emocional. Queria fazer logo a operação, pois das outras duas vezes deu certo, a dor passou.

Psicóloga: A senhora concorda com ele?

Paciente: Sim Eu estou sofrendo muito e tenho certeza que o meu problema é emocional.

Há cinco anos minha filha começou um namoro com um professor da mesma escola em que leciona. O namoro ia muito bem, até que no início de 2001 ele começou a realizar uma série de exames na clínica de Moléstias Infecto Contagiosas do Hospital do Servidor Publico Estadual (HSPE), sendo diagnosticado AIDS (Síndrome de Imunodeficiência Adquirida). 
A partir desse diagnóstico, minha filha foi orientada pelo médico que acompanhava o namorado a também realizar exames, sendo positivo o seu resultado de HIV. No final de 2001 o rapaz faleceu (chora muito).

Ele não podia ter feito isso com a minha filha. Ela e a única coisa boa que me resta. Ele vai sofrer no fogo do inferno. Vai passar tudo o que fez conosco, pois Deus é justo. Deus vai trocar o sangue da minha filha. Ela vai ficar curada.

Acredito que o tratamento é fundamental para a minha filha, mas a cura está apenas nas mãos de Deus.

Psicóloga: Quantos filhos a senhora tem?

Paciente: Tenho duas filhas, sendo que uma delas é a minha sobrinha, filha de uma irmã mais velha, que eu adotei, pois a minha irmã não quis a própria filha, falando que não estava preparada para a maternidade.

O pai da minha filha faleceu quando ela estava com um ano e seis meses, devido a enfarte.

Já fui casada antes de casar com o pai dessa filha. O meu primeiro casamento foi muito difícil: o meu marido queria sexo comigo 24 horas por dia. Como eu não queria ele achava que eu tinha outro homem e pôr essa razão brigava muito comigo.

Nesse primeiro casamento, minha sobrinha que é a que eu adotei veio morar conosco e logo em seguida uma irmã do meu marido tambem veio morar lá em casa. Essa irmã dele era deficiente mental. Ela não sabia fazer nada direito, nem pentear o cabelo, escovar os dentes, nós tínhamos que fazer por ela.

Um dia voltei mais cedo para casa e peguei o meu marido fazendo sexo com essa irmã. Fiquei abalada, quis a separação, ele aceitou na hora. Acho que ele ficou com medo que eu fosse à polícia dar queixa dele. Eu só não fiz isso por que fiquei com dó da moça. Coitada ela não entendeu nada. Dois anos depois ela morreu não sei do que.

Psicóloga: Dona Martha vamos encerrar por hoje, voltaremos a conversar na próxima semana.

Paciente: Tudo bem, até a semana que vem. 


\section{SEGUNDA ENTREVISTA PSICOLÓGICA}

Psicóloga: Como a senhora passou a semana?

Paciente: Bem, mas preocupada com a doença da minha filha. As vezes acho que ela pode morrer logo, fico com um aperto no peito.(Chora)

Quando eu tive, a primeira dor nas costas foi em 1990, e eu acho que foi por que eu fiquei muito nervosa com os problemas que estava passando com a outra filha, a adotiva.

Estava muito nervosa, e num determinado dia enquanto trabalhava em uma das máquinas na empresa, senti fortes dores nas costas, fui levada ao prontosocorro do HSPE, examinaram e falaram que eu tinha hérnia de disco. Operei e depois de dois anos voltei a sentir dor e operei novamente por causa da hérnia de disco.

Agora está doendo de novo, mas o médico disse que não vai mais me operar e fez o encaminhamento para cá. (Pausa)

A minha filha adotiva estava casada com um traficante de drogas, assassinado em 1990. Fiquei com muito medo que a minha filha adotiva tambem morresse, pois quando eles matam um matam a família toda.

Ele vendia drogas dentro de casa e acho que tambem devia usar. (Pausa) Não gostava de ir à casa deles, ele era esquisito, não era de falar. Só falava boa noite e ia para o quarto. Eu ficava sem graça e logo ia embora, às vezes queria ficar mais com a minha filha, mas acabava indo logo embora.

Quando me casei pela segunda vez, comecei a trabalhar numa empresa e ganhava mais. (Pausa) O meu segundo marido era bom, queria conforto dentro de casa e como eu já ganhava mais ajudava a comprar o que precisava. Foi uma época boa, pena que ele morreu cedo.

Estou com ordem de despejo, pois há alguns meses, não pago o aluguel. (Pausa) Mas o Senhor falou que não serei despejada e que em breve ele libertará minha filha da enfermidade.

Penso muito nas minhas filhas e tenho muito medo que algo aconteça a elas. Uma por causa da doença e a adotiva de ser assassinada como o marido foi. Bem, olhei no relógio já deu a hora, né?

Psicóloga: É, semana que vem continuaremos. 


\section{Análise das entrevistas:}

A história de vida da paciente é marcada por tragédias como: várias mortes e as decepções na vida conjugal.

Relações incestuosas são mantidas parecendo haver a necessidade de limites para a figura masculina que lesa principalmente a figura feminina (primeiro marido tem relações sexuais com a irmã deficiente mental). O segundo marido morre, deixando-a sozinha com uma filha para criar.

Os dois genros também decepcionaram bastante a paciente. Um infecta sua filha com o vírus da AIDS (Síndrome de Imunodeficiência Adquirida), o outro é traficante e é assassinado.

Os homens são ou tornam-se ausentes, sobretudo após lesarem as mulheres que aparecem como debilitadas e frágeis: a irmã do primeiro marido é deficiente mental, uma das suas filhas é HIV positivo, a outra foi abandonada pela mãe, em função de não evidenciar condições para assumir a maternidade. Ela tem a saúde abalada e esta devendo o aluguel.

Todavia, há a crença de que o grande pai (Deus) resolva os problemas: puna o genro pôr ter infectado a filha, libertando-a da doença crônica e ajude a paciente a pagar o aluguel atrasado.

A paciente concorda com o médico no sentido de que sua dor nas costas é emocional, trazendo questões nas entrevistas psicológicas relacionadas às inúmeras frustrações ao longo da vida.

Possivelmente, a paciente não comentava sobre o que lhe acontecia, na medida em que diz estar fazendo isso apenas nas sessões. Essa atitude sugere que durante um grande período de tempo não lhe foi possível falar sobre o que estava acontecendo, isolando-se e voltando-se para a religião como a única forma de alento e soluções para as suas dificuldades. A crença mítica é onde a paciente encontra apoio para suportar o sofrimento que caracteriza sua historia de vida.

Há conflitos relacionados à figura masculina: ora é percebida como ausente e destrutiva, ora é percebida como generosa, onipresente, onipotente e que resolverá todos os seus problemas. 


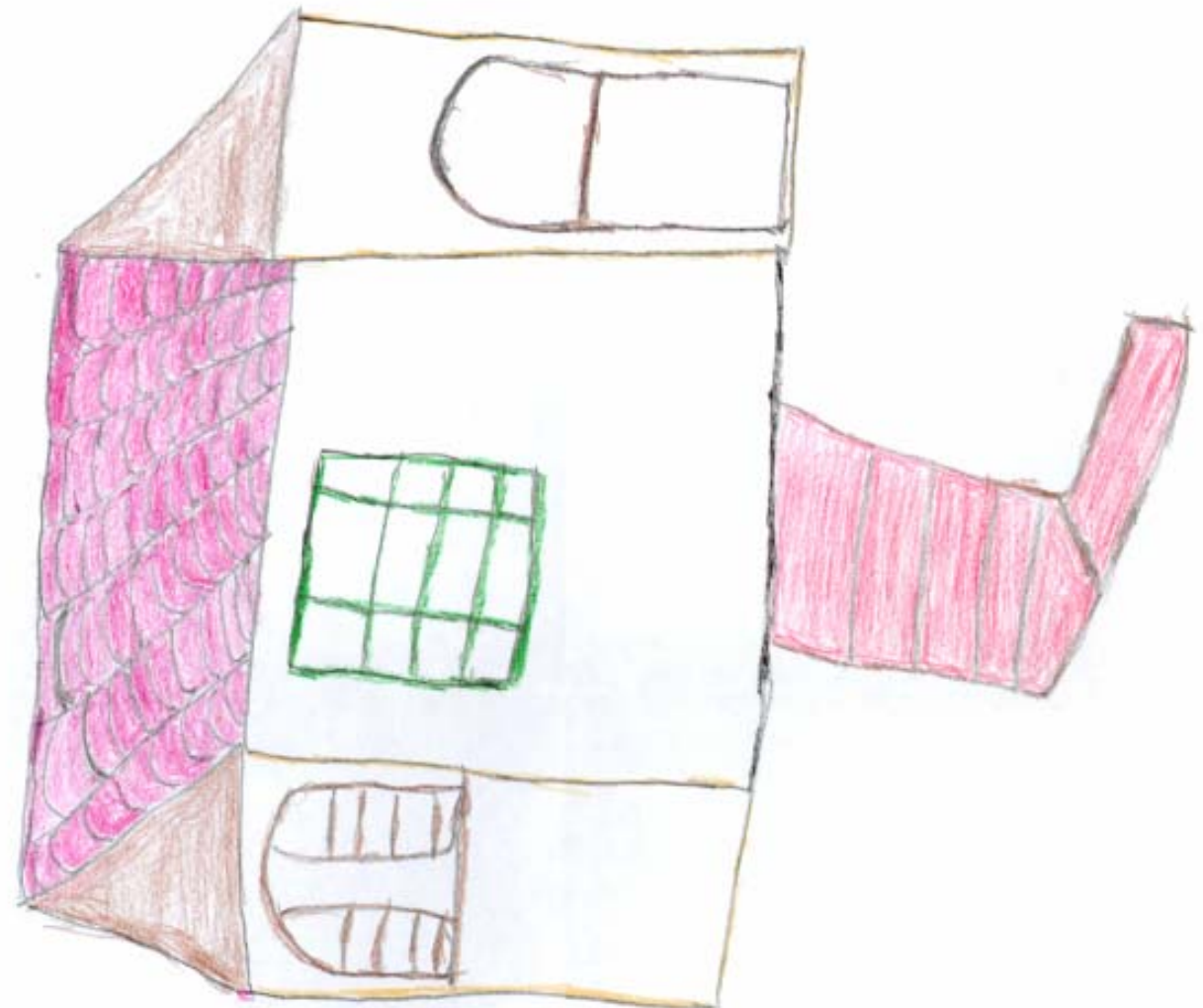

Fig.1 


\section{Análise dinâmica do desenho da casa:}

\section{Fig.1, p.58}

A escada que deveria facilitar o acesso à casa, não tem serventia, pois termina na parede, fazendo-nos pensar que os relacionamentos humanos ficam mais centralizados dentro da casa com restritas possibilidades de intercâmbios afetivos com o social. Essas restrições podem contribuir para a dificuldade de expressão, principalmente relacionadas ao seu sofrimento, mencionadas nas entrevistas psicológicas.

A cor usada para pintar a escada reflete que os estímulos que chegam de fora são intensos, e assim o sendo são ameaçadores. Portanto, sua entrada é dificultada pelo posicionamento da escada.

O colorido é cheio no telhado e na escada, alias há uma certa semelhança das cores utilizadas na escada e em uma parte do telhado, sugerindo intensos sentimentos de ansiedade tanto nos envolvimentos sociais quanto nos familiares, que invadem o aparato intelectual trazendo dificuldades no que se refere a sua articulação e elaboração dos conflitos emocionais.

Por outro lado, a cor esta presente nos contornos: das paredes, das janelas e da porta sugerindo interesse pelo envolvimento afetivo com o social, apesar da ansiedade que esse contato causa na paciente. O predomínio da ausência de cor dentro da casa sinaliza o pouco investimento afetivo nas ligações familiares.

A localização do desenho na folha de papel, mais voltada para o lado direito do papel, sugere relações familiares mais voltadas para o meio ambiente do que para o âmbito familiar. A porta está desenhada tanto do lado direito do papel quanto da casa, sugerindo um possível intercâmbio com o mundo externo.

Assim sendo, o voltar-se para o externo, pode abrir uma possibilidade para a paciente tratar o sofrimento originado nas decepções da sua vida, e não se aprisionar na amargura das tragédias experimentadas tanto no seu relacionamento conjugal, quanto no problema de saúde de uma das filhas e a apreensão pela morte da outra filha.

\section{Associação ao desenho da casa:}

“Essa casa é mais ou menos a casa que eu morei. Morava eu, o marido depois veio a Luiza (adotiva) e após dois anos veio a Silvia (cunhada) e depois a Meire 
(filha). Mas nessa época eu tinha um marido que só pensava em sexo 24 horas pôr dia, pois ele não tinha o Senhor no coração. Depois me separei e conheci o pai da Meire. Vivemos cinco anos juntos e quando estava com dois anos de casada engravidei e ele não quis. Pediu para eu abortar, mas decidi ter o meu filho. Ele não queria, pois achava que não ia ver o filho crescer, porque sofria do coração.

Nessa casa, minha irmã vinha à tarde, fazíamos bolo para o café. Mas aí veio a desgraça. A irmã do meu marido veio morar com a gente. Ela era débil mental, tinha que ensinar a tomar banho, escovar o cabelo, parecia uma criança. Ela morreu com 37 anos.

Os momentos de alegria nessa casa foram poucos, de tristeza foram muitos.

Fui criada sem mãe que faleceu quando eu tinha nove anos. Fui morar com a minha tia, mas ela casou, aí fui morar com a minha avó, mas ela faleceu e aí fui morar com o meu pai. Foi horrível, ele chagava bêbado, batia muito em nós. Eu tava com 11 anos, minha irmã do meio tinha 12 anos e a mais velha estava com 16 anos. Foi uma época difícil. Essa casa fez lembrar todo esse sofrimento”

\section{Análise da associação ao desenho da casa:}

O desenho da casa estimulou a lembrança da vivência sofrida que experimentou anteriormente. Repete na associação ao desenho os conteúdos já mencionados na entrevista, evidenciando o quanto esse sofrimento necessita ser elaborado, bem como, a condição que ela traz de o tratar. O estímulo gráfico da casa e a mobilização das entrevistas psicológicas parecem ter permitido à paciente a comunicação, bastante clara, do acentuado sofrimento vivido na infância, caracterizado pelo desamparo e pela hostilidade.

A associação nos ajuda a entender a ênfase das cores apenas nos contornos da casa, não havia muito no que investir afetivamente dentro de casa. 


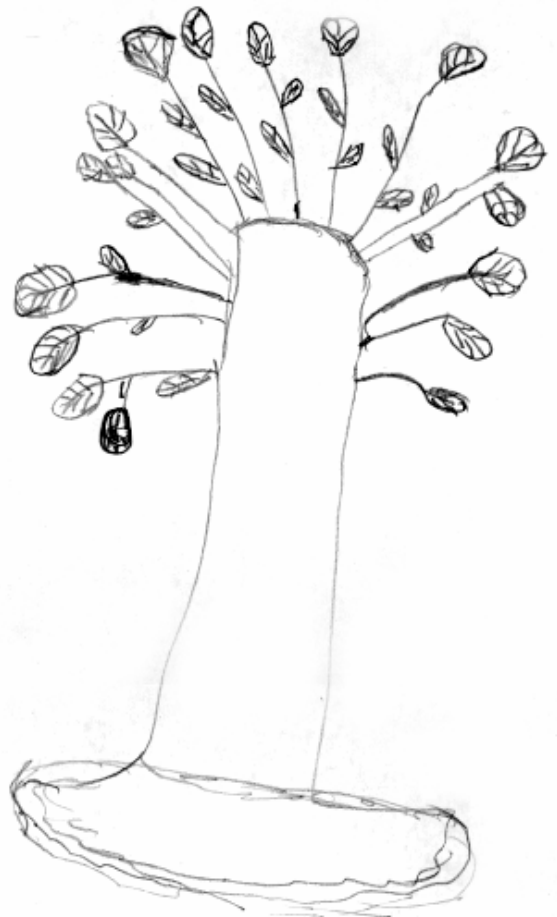

Fig.2 


\section{Análise dinâmica do desenho da árvore:}

\section{Fig 2, p.61}

A sua localização no papel evidencia tendência ao mundo da fantasia sem muito interesse pela análise objetiva dos fatos do meio ambiente. A presença de folhas é sugestiva de preocupação com a saúde tanto física quanto mental.

A forma fálica do desenho da árvore sugere preocupação com as questões sexuais. Interligando a forma do desenho com a sua localização na folha, diríamos que as questões sexuais podem envolver muito a paciente, gerando culpa. Esse sentimento parece ganhar mais dimensão se considerarmos a associação ao desenho da casa onde 'pensar em sexo 24 horas por dia' desagrada ao Senhor.

A ausência da copa sinaliza déficit no domínio das fantasias que acrescido da falta de cor no desenho sugere tentativa de conter os impulsos sexuais pela repressão.

O repassar várias vezes a base da árvore evidencia o esforço para se manter respondendo as exigências ambientais mesmo sem ter tido modelos significativos de identificação.

A base arredondada da árvore indica necessidade da figura materna mais próxima.

\section{Associação ao desenho da árvore:}

"Essa e a história da minha vida. Onde eu morava tinha um pé de abacate. Eu comi muito abacate na minha infância. Ele ficava do lado de um pé de limão de casca grossa. O abacateiro é uma arvore muito forte, e vivi muitos anos”.

\section{Análise da associação ao desenho da árvore:}

A identificação com uma árvore forte parece refletir o esforço que a paciente faz para resistir ao sofrimento que vem passando ao longo da vida.

Na associação a árvore fica perto de um limoeiro de casca grossa. Poderíamos pensar que a paciente necessita da solidez e da proteção de modelos de identificação que possam ajudá-la a suportar o sofrimento das vicissitudes da vida.

Há menção de que a paciente sentia-se nutrida pela mãe até aos nove anos de idade devido a morte da mãe, sendo lançada aos maus tratos, sobretudo da figura paterna. Nesse sentido, há necessidade de nutrição, de uma figura materna provedora 
de carinho, de suporte e principalmente de proteção. Há que se nutrir essa paciente com a possibilidade de um tratamento psicoterápico para que à medida que for elaborando as frustrações da sua vida, possamos proporcionar-lhe redução da sua dor lombar.

É importante que o processo psicoterápico possa proporcionar desenvolvimento de condutas protetoras, uma vez que após a morte da mãe perde a referência nutritiva e passa por vivencias desprovidas de proteção, segurança ao enfrentar situações hostis e agressivas. 


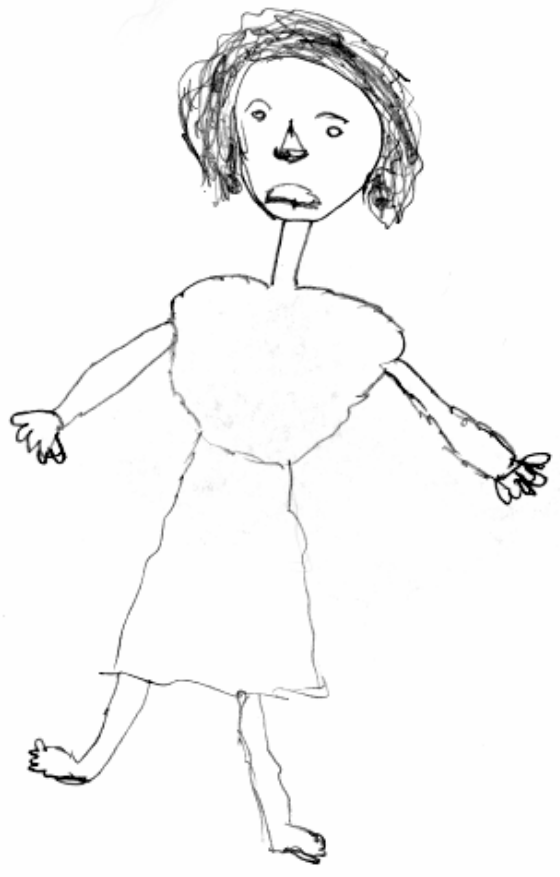

Fig.3 


\section{Análise dinâmica do desenho da primeira pessoa:}

\section{Fig.3, p. 64}

A ausência de base para o desenho, o traçado trêmulo do corpo e os olhos vazados evidenciam modelo materno insuficiente para garantir um processo de identificação.

A precariedade da identificação com a mãe associada à boca aberta no desenho da figura humana parecem configurar expressão de tristeza, de insatisfação e de medo.

Esses sentimentos estão também representados no traçado trêmulo do braço esquerdo da figura da mulher, sugerindo tensão e insegurança no envolvimento com o outro, provavelmente devido às várias frustrações experimentadas na relação humana.

As vivências dolorosas ao longo da vida desgastaram a paciente que parece buscar no pronunciado do desenho do nariz, respirar intensamente, evidenciando recursos não só para enfrentar os dissabores bem como para se mobilizar em prol de uma vida melhor para si.

\section{Associação ao desenho da primeira pessoa:}

“Essa e a minha avó, mãe da minha mãe. Ela ajudava muito a minha mãe, às vezes pagava o nosso aluguel. Não conheci o meu avô. Ele faleceu na cadeia, pois era louco e num acesso de loucura matou um homem, isso era o que minha avó e minha mãe falavam. Quando a minha avó faleceu fomos morar com o pai, e ai foi só sofrimento. Apanhava sem saber porque, era só chegar bêbado em casa e já ia batendo na gente”.

\section{Análise da associação ao desenho da primeira pessoa:}

Ênfase nos aspectos negativos da figura masculina e a importância da figura materna como provedora. Esforço acentuado para prover uma vez que o grafismo revela fragilidade no posicionamento frente às exigências.

Ausência da figura feminina e como conseqüência sofrimento. 

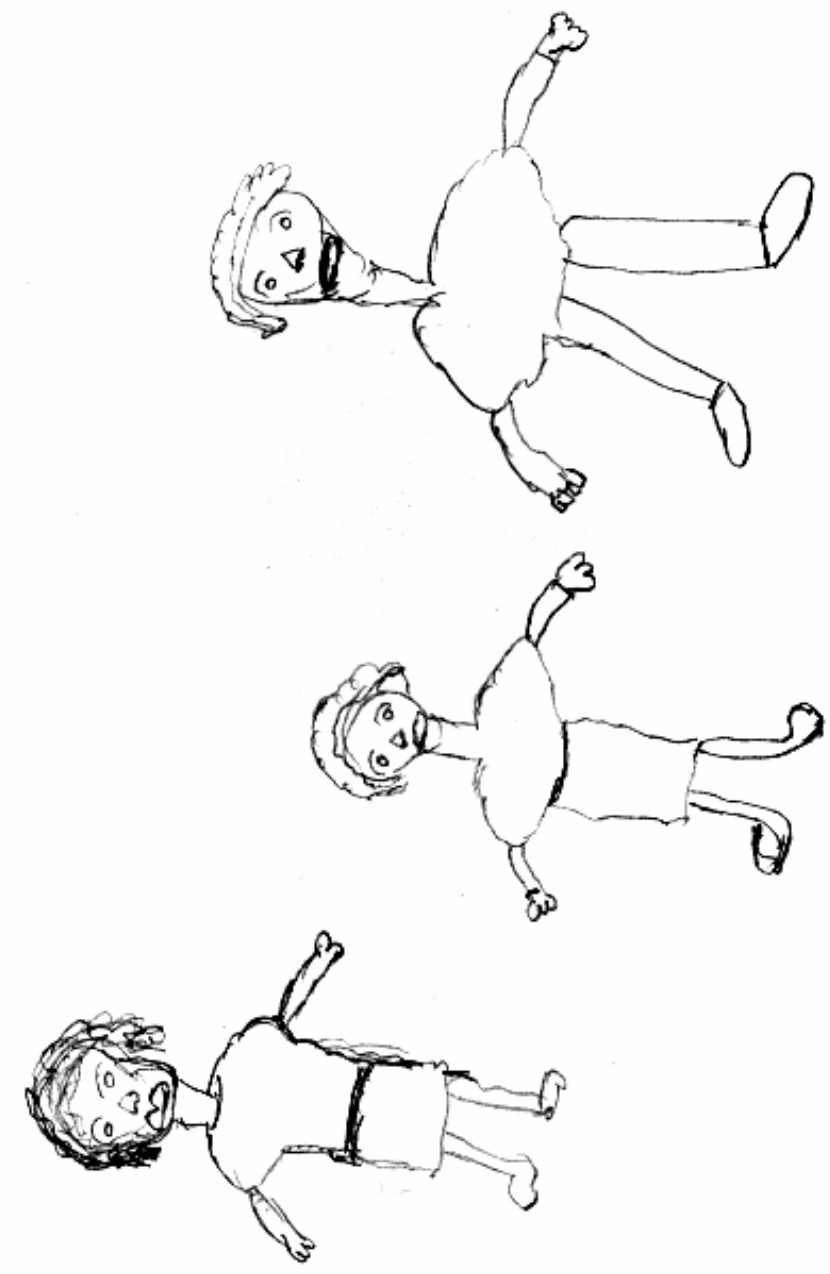

Fig.4 


\section{Análise dinâmica do desenho da segunda pessoa:}

\section{Fig 4, p.66}

Desenha uma família no lugar da figura de sexo oposto, sinalizando a necessidade de ter uma família. Desenho sem linha de solo, corpo trêmulo e olhos vazados evidenciando insegurança no enfrentamento das solicitações ambientais.

O sombreado no corpo da figura que representa a paciente indica sinais de sofrimento referente a perdas importantes.

Ausência da figura feminina e como conseqüência sofrimento.

\section{Associação ao desenho da segunda pessoa:}

“Vou dar um título: 'A esperança é a última que morre' Sou eu, a Meire e o pai dela. Ele já esta morto. Ela das aulas, luta para viver tem sonhos de ficar boa. Eu confio em Deus, acho que ele irá trocar o sangue dela. Ela irá casar ter filhos será feliz. Confio em Deus e em Jesus Cristo”.

\section{Análise da associação ao desenho da segunda pessoa:}

Necessidade ter uma família onde a mulher aparece como figura provedora e protetora, sobretudo da hostilidade da figura masculina.

Mais uma vez a associação ao desenho reflete sua historia de vida e assim como a filha, a paciente também luta para sobreviver às tragédias da sua vida.

O propósito de vida é bastante ambicioso, e sua realização somente é possível no plano da fantasia. A credibilidade acentuada na ajuda divina evidencia o único recurso possível de amparo para suportar o sofrimento de tantas perdas e maus tratos.

\section{ENTREVISTA DEVOLUTIVA}

Psicóloga: Bom dia. Como tem passado?

Paciente: Bom dia. Minha filha esteve no hospital semana passada para fazer uns exames, e o médico disse que ela estava bem. Fiquei contente. Tenho muito medo que ela morra. Graças a Deus ela se cuida, vem ao hospital quando tem consulta, faz os exames tudo direitinho. A minha outra filha, esta vendo se arruma um emprego, um bico, qualquer coisa já ajuda. Ela tem medo de sair de casa e eu também fico preocupada, tenho receio que alguém da gang que matou o marido dela 
faça algo com ela. O jeito é rezar muito e pedir proteção a Deus. Sabe, que as dores aliviaram, estou tomando o remédio e logo vou começar a fisioterapia.

Psicóloga: Dona Martha, a senhora é muito religiosa...(paciente interrompe)

Paciente: Sou, e acho que não dá para você viver sem a ajuda e proteção do Senhor. Se você tem uma aflição, ele vai tirar isso de você.

Psicóloga: É, Dona Martha e a senhora já teve e continua tendo muitas aflições.

Paciente: Sabe, a gente não tem sossego na vida, quando não é uma coisa é outra, e assim a gente vai vivendo.

Psicóloga: Então, a senhora já passou por muitas situações na vida que a deixaram muito aborrecida (paciente acena com a cabeça, concordando com o que estamos falando). O seu primeiro casamento...

Paciente: (Interrompe) Nossa! Aquilo foi um horror. Na verdade eu casei porque queria sair da casa do meu pai. Eu já sabia que ia ser difícil, mas foi pior do que eu imaginei. Foi um pesadelo que eu achava que nunca ia terminar.

Psicóloga: Pois é esse primeiro casamento foi um pesadelo, mas antes da senhora casar-se a convivência com o seu pai era bastante difícil também.

Paciente: Ah! Outro horror, eu apanhava sem saber porque, ele chegava bêbado, e batia de cinta. Uma vez levei uma cintada, que fiquei marcada por muito tempo. Foi muito difícil.

Psicóloga: O convívio com o seu pai foi difícil o primeiro casamento também; o que estava bom foi o segundo casamento, mas o seu marido morreu.

Paciente: (Chora) Pausa. Foi a única coisa boa da vida, claro que tenho as minhas filhas que são tudo para mim, mas estou falando de uma época feliz que durou pouco. De domingo ficávamos um tempão sentados na mesa da cozinha depois de almoçar, conversando fazendo planos para o futuro. Ele era um homem que gostava de conforto e trabalhava para isso. Coitado, morreu moço, cheio de planos (Parece pensativa, pausa).

Psicóloga: A senhora viveu situações boas, mas parece que as dificuldades foram em maior número.

Paciente: É verdade, minha vida não foi fácil, mas fazer o quê, o negócio e tocar a vida com fé em Deus. 
Psicóloga: A crença em Deus ajuda a senhora agüentar os aborrecimentos. Eles foram muitos e a senhora tem conseguido reagir, mesmo preocupada com as suas filhas, a senhora encontrou na religião o apoio para suportar todo o sofrimento que tem vivido.

A senhora disse que concordou com o médico, quando ele disse que a sua dor era emocional, e parece que ela além de ser em função da hérnia de disco, também refere-se a todo o sofrimento que a senhora já viveu e continua vivendo.

Paciente: (Esboça um sorriso) É! Dói de um jeito diferente...

Psicóloga: Como assim, Dona Martha?

Paciente: É a dor no peito de tristeza, sabe da gente não poder fazer nada e o problema tá ali.

Psicóloga: Mas a senhora ajuda suas filhas, dá apoio a elas, conversa com elas, e isso faz bem tanto a elas quanto a senhora.

Paciente: Nisso a senhora tem toda razão eu sempre conversei muito com as minhas filhas. O que eu nunca tive procurei fazer com elas. É bom falar com alguém sobre o que acontece com a gente. Não importa se é coisa boa ou ruim.

Psicóloga: Dona Martha seria bom para a senhora fazer um acompanhamento psicológico, ter um lugar para falar sobre esses aborrecimentos e aliviar a dor da tristeza...

Paciente: (Interrompe) Ah! Eu faço sim, é com a senhora mesmo.

Psicóloga: Não será com outra psicóloga. A senhora receberá uma ligação para comparecer aqui para iniciar o tratamento.

Paciente: Está bem o telefone de casa a senhora já tem, mas vou deixar também o do trabalho da Meire, pois vocês podem ligar em um dia que eu esteja aqui no hospital e eu não quero perder. Foi bom vir aqui, gostei muito e continuar vai me fazer bem. Muito Obrigada.

Psicóloga: Até logo, leve o telefone da Psicologia, caso precise falar conosco.

Paciente: Obrigada e até logo. Fique com Deus.

\section{Integração dos dados obtidos no Psicodiagnóstico:}

A paciente reporta que sua dor lombar teve início quando seu genro foi assassinado. Passou a ficar tensa temendo que sua filha também fosse assassinada. 
No entanto, essa experiência é uma dentre as várias situações de sofrimento vividas pela paciente. Sua história de vida se caracteriza pela hostilidade da figura paterna, dificuldades no primeiro casamento, falecimento do segundo marido com quem mantinha uma relação conjugal satisfatória, problema grave de saúde de uma das filhas e a ameaça de perder a outra filha assassinada, já mencionada pela paciente.

Há que se perguntar como a paciente agüentou e continua agüentando tudo isso? A resposta para a nossa questão parece estar no apego à religião. A esperança depositada na cura da filha traz alento e afasta a dor referente à possibilidade dessa perda. Assim sendo, a religião aparece como a única forma possível de amparo para a paciente.

Em O Mal-Estar na Civilização, Freud (1930[1929]/1969) menciona que o apego à religião constitui-se em uma das maneiras que a pessoa encontra para mitigar o sofrimento causado pelas vicissitudes da vida. À religião deve-se a formação e o término do propósito da vida humana. Nesse escrito, Freud (1930[1929]/1969,p.92) considera:

O homem comum só pode imaginar a Providência cuidadosa sob a figura de um pai ilimitadamente engrandecido. Apenas um ser desse tipo pode compreender as necessidades dos filhos dos homens, enternecer-se com suas preces e aplacar-se com os sinais do seu remorso.

Há outras formas de se diluir o desprazer, porém a religião condensa-as todas nela mesma, estabelecendo de modo exclusivamente unilateral a direção para o alcance da felicidade e proteção irrestrita do sofrimento.

O movimento estritamente voltado para si da religião convida os adeptos a uma distorção das características da realidade externa, estimulando uma visão que se aproxima do delírio, principalmente quando a questão é terminar com o sofrimento.

Nesse sentido, se a pessoa entrega-se à crença religiosa como a única forma de se afastar do desprazer, evidencia uma submissão incondicional, o que pode comprometer a analise objetiva dos eventos da realidade e, por conseguinte a adaptação às circunstâncias do mundo externo.

Martha apesar de manifestar intenso apego à religião também é capaz de fazer uma análise criteriosa daquilo que a realidade externa oferece como uma forma de também trazer prazer. O crédito atribuído ao tratamento médico de sua filha, bem como a aceitação da orientação do neurologista quanto ao seu encaminhamento para 
a seção de Psicologia, devido a dor nas costas, sinalizam o empenho na busca da felicidade por meio de outros recursos, distanciando-a da prioridade do caráter religioso.

O processo álgico pode estar associado às vivências sofridas ao longo da sua vida. É bem provável que as dificuldades tenham-se iniciado aos nove anos com a morte da mãe. A partir desse falecimento a paciente parece ter iniciado sua via cruxis: mora um tempo com alguns parentes até que devido a morte da avó, passa a morar com o pai, sendo submetida aos seus maus tratos. Decepciona-se demasiadamente com o primeiro casamento e o segundo marido com que se relacionava bem, morre. As filhas preocupam-na, pois uma é soro positivo, cujo marido morreu devido a AIDS, e a outra foi casada com um traficante de drogas assassinado, trazendo a ameaça de que algo semelhante possa acontecer com essa filha.

O convívio constante com tanto sofrimento parece agora concentrado na dor nas costas. Os médicos fazem o encaminhamento para a Psicologia justificando tratar-se de problemática emocional, hipótese essa aceita pela paciente que durante as entrevistas psicológicas e a aplicação do teste projetivo explica-nos o sentido do termo emocional mencionado no seu encaminhamento.

Segundo Nasio (1997), a dor psíquica se localiza na ruptura do laço entre aquele que ama e seu objeto amado. Frente a essa ruptura o equilíbrio do sistema psíquico é danificado e o eu consegue perceber o caos das tensões pulsionais, experimentando uma dor insuportável.

Baseando-se na visão metapsicológica, Nasio (1997, p.26) define dor psíquica da seguinte maneira:

É o afeto que exprime na consciência a percepção pelo eu - percepção orientada para o interior

- do estado de choque, do estado de comoção pulsional (trauma) provocado pela ruptura, não da barreira periférica do eu, como no caso da dor corporal, mas pela ruptura súbita do laço que nos liga ao outro eleito. Aqui, a dor é dor do trauma.

O tratamento psicoterápico poderá representar o lugar do abacateiro da associação ao desenho da árvore, (Fig.2, p.61) nutrindo a paciente com acolhimento relacionado ao aspecto nutritivo materno, oferecendo-lhe a possibilidade de falar sobre as vivências danosas da sua vida para que as possa elaborar. 


\section{Sujeito 2}

Paciente: Vilma (nome fictício) 53 anos, viúva, cozinheira de uma escola pública do estado de São Paulo, tem quatro filhos, sendo que a filha mais velha é casada e tem uma filha de dois anos.

Histórico da hérnia de disco:

Em 1999, no exame físico e na ressonância magnética foi diagnosticada hérnia de disco sendo submetida à cirurgia, com remissão do sintoma doloroso.

No início de 2002 voltou a procurar o ambulatório da Neurocirurgia queixando-se de fortes dores na coluna. O exame clínico caracterizado pelo exame físico e ressonância magnética evidenciaram hérnia de disco, ainda pequena, o que não justificaria cirurgia e sim tratamento medicamentoso e fisioterapia. Todavia, a paciente insiste com os médicos que desejaria operar, pois não agüenta as dores, apesar de não ter feito o acompanhamento fisioterápico, fazendo apenas uso de medicação antiinflamatória.

O encaminhamento para a seção de Psicologia não fez sentido para Vilma, pois na primeira vez que procurou os neurocirurgiões logo foi operada. Entendeu que nesse momento, seria rotina da clínica de neurocirurgia passar também na Psicologia, por essa razão compareceu ao atendimento.

\section{PRIMEIRA ENTREVISTA PSICOLÓGICA}

Psicóloga: Qual o motivo da consulta na Psicologia?

Paciente: O médico pediu uma avaliação psicológica, mas não vejo necessidade, o que tem a dor nas costas com isso aqui (referindo-se à seção de Psicologia). Queria logo operar e pronto, foi assim da primeira vez que operei, foi ótimo operei e passou a dor. Agora a hérnia voltou, então precisa operar de novo e pronto.

A dor que sinto é por causa do trabalho que faço. Sou cozinheira e mexo panelas enormes cheias de comida, então fica muito pesado. Você imagina uma panela cheia de arroz para mexer, imagina uma panela para fazer comida para todas as crianças da escola, ela é muito grande, acho que deve ser igual a do hospital, por que para fazer comida para um monte de gente tem ser grande né? 
Moro com uma filha, com a neta do primeiro filho e uma sobrinha. Não me dou bem com essa filha, ela só arruma para namorar homens casados. Você imagina que quando ela engravidou, eu só fiquei sabendo quando ela já estava de três meses. Aí, vem com uma estória furada de que teve um aborto espontâneo e perdeu a criança. Eu não acredito, ela provocou esse aborto, por que o namorado não queria esse filho pelo fato dele já ter dois no seu casamento. Não sei por que ele só namora homens casados, não pode dar certo nunca, eles já têm compromisso. Bem, quando o namoro acaba ela diz que a culpada sou eu, por que eu me intrometo demais na vida dela dizendo a toda hora que não vai dar certo, pois eles são casados. Eu nem precisava falar, por que ta na cara que isso não pode ir pra frente mesmo.

Psicóloga: A senhora acha que a sua dor nas costa é só por causa da sua profissão?

Paciente: Fica um pouco pensativa. O meu marido ficou inválido, devido à esclerose múltipla, então eu tinha que fazer muita força para virá-lo na cama várias vezes para que não ficasse com feridas pelo corpo. Acho que o esforço também ajudou a ter dor. Não o deixava molhado, estava sempre limpo. As pessoas ficavam admiradas dele não ter feridas apesar do longo tempo que estava acamado.

Ele fez tratamento durante dois anos e sete meses, mas ficou completamente inválido durante um ano e seis meses.

Durante o tempo que cuidei do meu marido, não contei com a ajuda dos filhos, tive que abrir mão das minhas coisas para cuidar dele. Ele não aceitava que outra pessoa cuidasse dele. Cuidei dele durante um ano e seis meses e depois ele faleceu.

O relacionamento com ele, sempre foi difícil, pois tudo tinha que ser do jeito que ele queria. Teve um monte de amantes, e eu sempre soube de todas, mesmo porque ele não fazia nada para esconder os casos dele. Sabe aquela coisa de homem: mostrar as outras mulheres era como se fosse um elogio para ele: eu consigo a mulher que quero.

Agora eu acho que ele me amava, pois caso contrário deixaria que outras pessoas cuidassem dele na doença.

Psicóloga: Que coisas a senhora deixou de fazer para cuidar dele?

Paciente: Deixei de trabalhar, de ter as minhas patroas das casas que eu trabalhava, que gostavam de mim. (Chora, pausa) 
Psicóloga: Dona Vilma, o nosso horário por hoje terminou, voltaremos a nos falar na semana que vem.

Paciente: Ah! Foi bom falar, parece que estou mais aliviada, até a próxima semana. Obrigada.

\section{SEGUNDA ENTREVISTA PSICOLÓGICA}

Na segunda entrevista apresentou-se bastante desanimada e informou que não estava dormindo bem.

Psicóloga: Por que a senhora não está dormindo bem?

Paciente: Aborrecimento, sempre fiz tudo pelos outros e que ninguém se preocupa comigo. Tenho quatro filhos e nenhum deles pergunta se estou precisando de alguma coisa. Venho sozinha ao hospital passo pelas consultas e nenhum dos filhos pergunta como eu estou.

Sinto-me só. Eu sempre fui a filha predileta do meu pai, ele fazia todas as minhas vontades. Acho que passei a sentir solidão desde o dia em que meu pai morreu, quando ele morreu, eu tinha nove anos.

Você sabe que ainda no leito da doença, do meu pai, minha mãe já estava me prometendo para a minha madrinha. Somos em nove irmãos, e minha mãe dizia: que os outros oito eram fracos e que eu era a mais inteligente e por isso era forte e poderia morar com a minha madrinha. Minha mãe estava sem dinheiro e eu morando com a minha madrinha seria uma pessoa a menos na casa dando despesa.

Na casa da minha madrinha eu era a empregada da casa. Fazia toda a faxina e quando estava com 12 anos já cozinhava também.

Minha mãe foi para Minas Gerais, viver com outro homem e com os meus oito irmãos. Aliás, minha mãe traia o meu pai, com essa pessoa com quem ela foi morar em Minas Gerais. Nunca mais vi minha mãe nem os meus irmãos. Há uns quatro anos ela faleceu, eu fui ao seu enterro, vi meus irmãos, falei com eles, mas é como se nem fossem irmãos, passou tanto tempo que a gente até esquece que tem irmão.

Eu fiquei na casa da minha madrinha até casar. Casei com 18 anos, tive um filho atrás do outro e hoje ninguém liga para mim. A caçula tem 27 anos é solteira e mora comigo. O filho mais velho tem 33 anos, é viúvo e eu cuido da filha dele que tem cinco anos. Minha nora morreu de acidente de carro na estrada. Estavam voltando do carnaval chovia muito, o carro capotou e ela morreu no local. Meu filho 
se machucou muito e a minha neta estava comigo, pois como era muito pequena não viajou com eles.

As gêmeas têm 29 anos são casadas e moram na Bahia, acho que estão bem, pois a gente não se fala há muito tempo.

\section{Análise das entrevistas:}

Chama-nos a atenção a mudança de atitude da paciente frente ao atendimento psicológico. Em princípio, apenas aceitou o atendimento psicológico por achar que seria condição fundamental, para ser operada da hérnia de disco. No entanto, com o passar da primeira entrevista, já se mostrava mais disponível para responder às questões que eram feitas.

A dúvida quanto ao encaminhamento para a seção de Psicologia, parece ter cedido lugar à possibilidade de falar sobre assuntos que há muito tempo indispunham a paciente como os problemas vividos no casamento, a dificuldade de relacionamento com os filhos, e a sobrecarga de trabalho no campo profissional.

A paciente atribui a dor nas costas ao excesso de trabalho tanto na escola como no casamento em função da doença do marido. Em ambas as situações, a paciente aparece como aquela que tem que fazer pelo outro na medida em que esse está impossibilitado: as crianças não têm como cozinhar para si e o marido estava inválido devido à esclerose múltipla. O fazer pelo outro pode ter afastado a paciente da realização daquilo que de fato gostaria de estar concretizando, subtraindo-lhe tempo, ânimo e dedicação.

Quando o pai faleceu a paciente perdeu a pessoa que a acolhia, provavelmente a partir daí deu-se início às experiências de submissão à vontade alheia. A mãe decidiu por entregá-la à madrinha independente da sua escolha; no casamento o marido sempre fez o que quis, caracterizando uma relação unilateral na medida em que ela não era percebida.

A maneira como a paciente chegou à seção de Psicologia parece evidenciar o jeito como vem vivendo. Chegou à Psicologia porque entendeu que seria mais um passo a ser seguido para ser operada, obedecendo assim, a uma ordem de terceiros. 


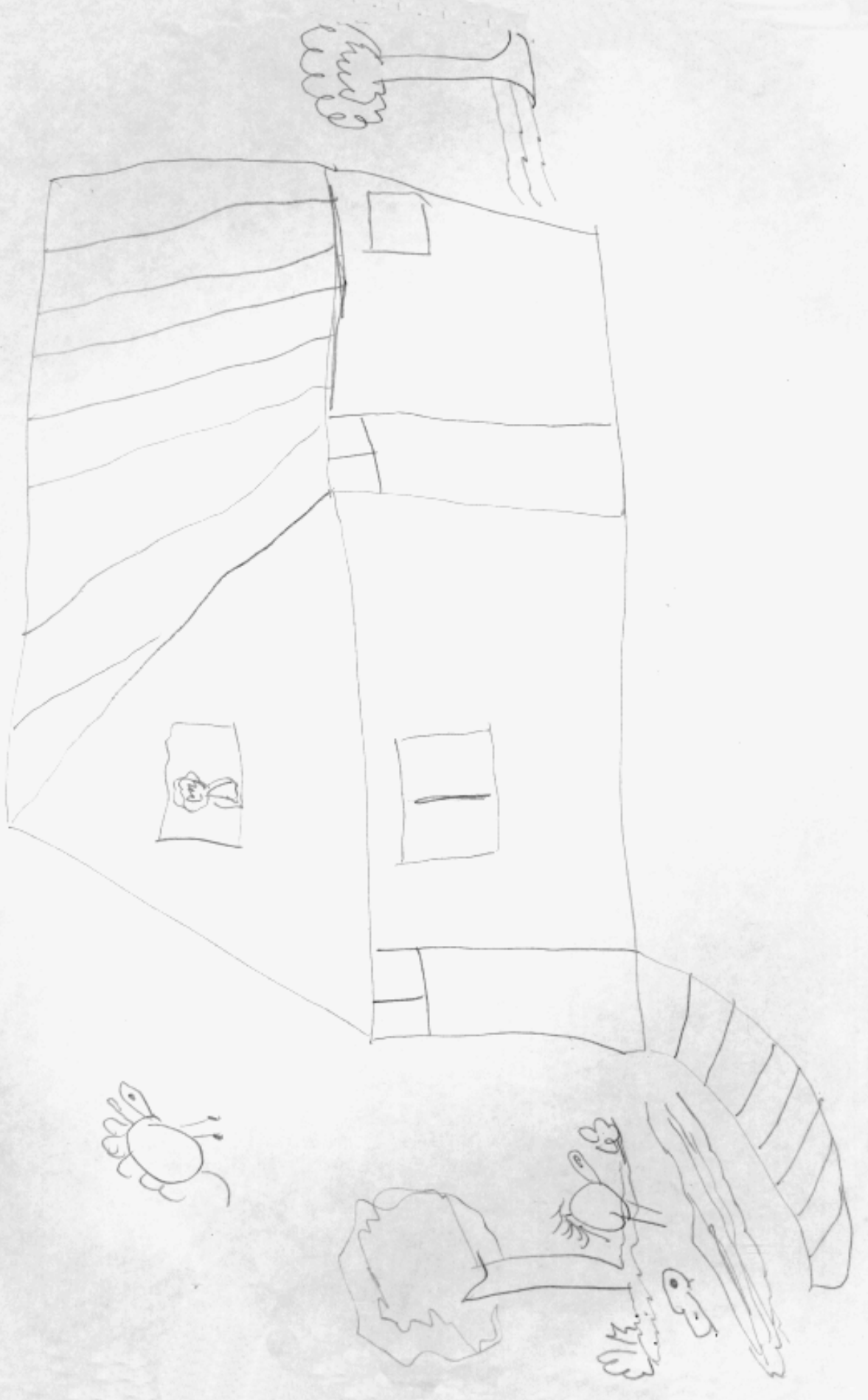

Fig.5 


\section{Análise dinâmica do desenho da casa:}

\section{Fig.5, p.76}

As adições de árvores, vegetação e animais ao desenho da casa refletem carência principalmente relacionada ao convívio familiar, denotando necessidade de buscar no social o que está precário no ambiente familiar. As adições estão fora da casa parecendo refletir que a criatividade, a produção o e movimento dinâmico estão fora da casa, de modo que tais habilidades encontram-se distanciadas das relações familiares.

O acesso a casa é difícil, na medida em que não há porta. As janelas garantem o intercâmbio com o mundo externo, porém de modo restrito. Há interesse pelos eventos ambientais, mas a mobilização para uma maior participação com os fatos do cotidiano encontra-se pautada ainda pela observação e planejamento e não pela ação. A atitude passiva frente à estimulação do meio ambiente, pode estar revelando um envolvimento muito intenso com as questões familiares que não permite uma participação mais efetiva com as circunstâncias externas.

A ausência da linha do solo no desenho da casa evidencia precariedade de padrões de conduta que auxiliam o desenvolvimento da autonomia. Denota ainda relações familiares sujeitas a qualquer tipo de influência externa não sendo possível discernir quanto à qualidade dos estímulos que chegam até a casa.

A nítida divisão dos cômodos, inclusive sem possibilidade alguma de comunicação entre eles parece sinalizar restrição significativa de envolvimento humano, sendo que o desenho acromático enfatiza o desinteresse afetivo na dinâmica familiar.

A convivência familiar pode ter exigido muito da paciente no sentido de continência para com as necessidades familiares e solicitação visando a manutenção do equilíbrio familiar, graficamente representado pelas árvores simetricamente posicionadas no desenho da casa.

\section{Associação ao desenho da casa:}

"É a casa que idealizo nos meus sonhos: grande, com quintal, muitas criações, plantas, flores, um rio correndo no fundo. Eu moro numa casa boa, ela é grande também, mas a do sonho é melhor. Esta casa está longe da cidade, eu moro sozinha e no final de semana os filhos vêm". 


\section{Análise da associação ao desenho da casa:}

O sonho expressa a possibilidade dos filhos irem até ela, que é exatamente o que ela não vive no seu cotidiano. Deseja uma relação com os filhos e uma relação que atraísse os filhos.

No desenho parece ser ela na janela à espera de alguém que não vem. 
79

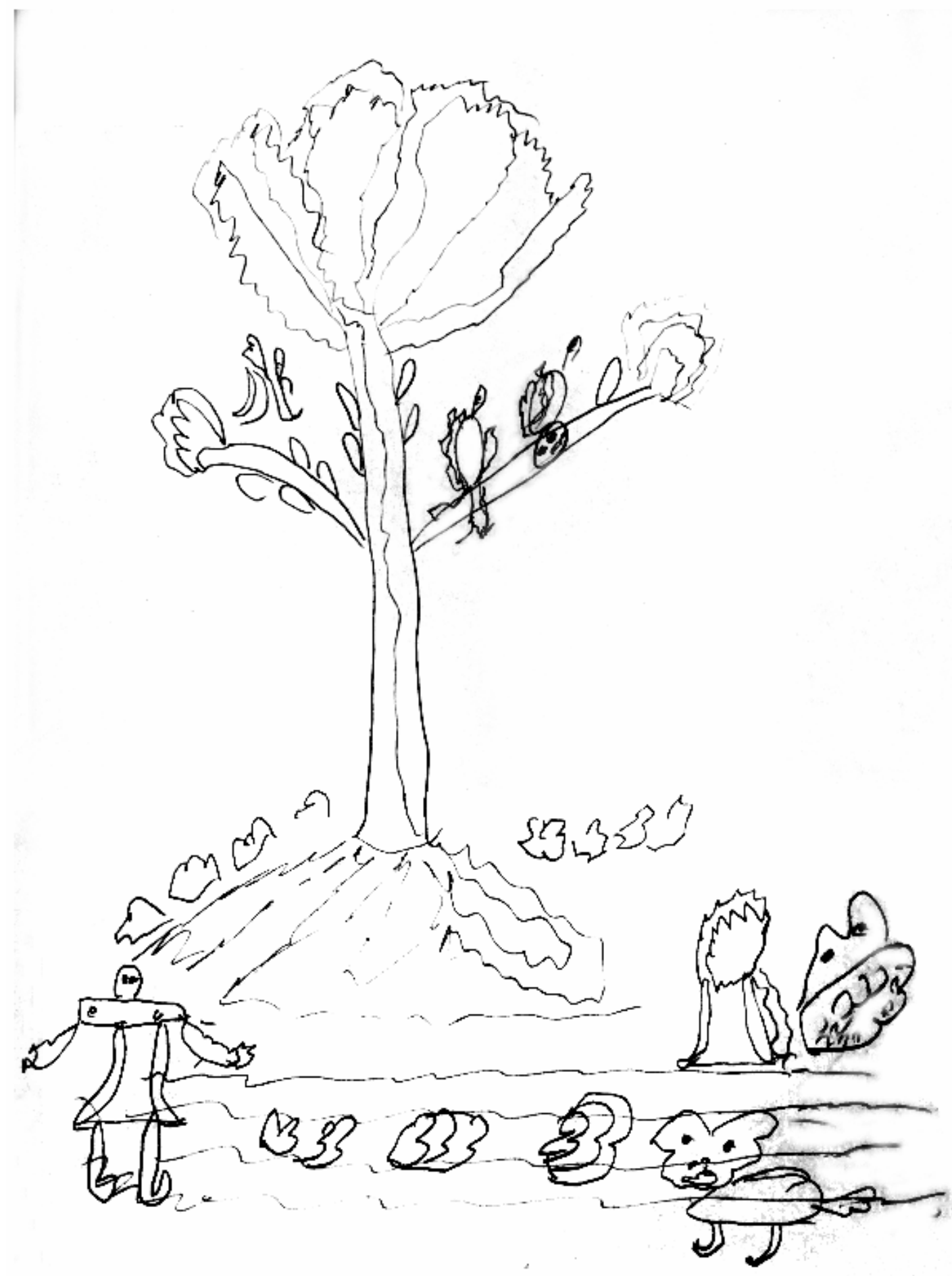

Fig.6 


\section{Análise dinâmica do desenho da árvore:}

\section{Fig.6, p.79}

As raízes aparentes denotam esforço da paciente para analisar de modo objetivo os fatos da realidade externa, uma vez que há forte tendência à subjetividade. Nota-se também a simetria no desenho da árvore evidenciando preocupação com a própria saúde.

A adição de elementos ao grafismo da árvore reflete a necessidade de agradar o outro, provavelmente para garantir sua atenção.

O traçado usado nas raízes assemelha-se ao da copa da árvore, sugerindo escassez de modelos significativos para a identificação e conseqüente prejuízo na autonomia, bem como para articular o potencial intelectual na elaboração de vivências conflituosas. O traçado contínuo no tronco sinaliza uma melhor condição ao longo do seu desenvolvimento, apesar de ter sido necessário esforço intenso por parte da paciente para manter-se adaptada às solicitações externas, na medida em que há sinais de sofrimento emocional acentuado ao longo desse desenvolvimento. Podemos supor um movimento em prol do convívio social, intensificando a produção principalmente voltada para a satisfação do outro.

O desenho da pessoa como um dos complementos do desenho da árvore revela alteração no esquema corporal, com indefinições no que se refere aos atributos femininos e masculinos, sugerindo comprometimento significativo da identidade.

\section{Associação ao desenho da árvore:}

“Às vezes é melhor gostar de bichos do que de pessoas. Os bichos não são ingratos. É uma árvore bem frondosa, é frutífera, uma mangueira, vai viver muitos anos para que os filhos digam que essa árvore foi a mãe deles quem plantou. Quando eu for dessa para uma vida melhor os filhos vissem o que a mãe deles fez. Quando os filhos são pequenos a mãe é a dona da casa, quando eles crescem eles mandam e o que é velho não tem mais valor.

Essa sou eu, estou olhando os animais dando comida para eles, vendo as plantas". 


\section{Análise da associação ao desenho da árvore:}

Descrédito no relacionamento humano, devido às decepções não elaboradas. Necessidade de valorização do outro, imagem de si mesma bastante inferiorizada, inconformismo devido à falta de reconhecimento. Percebe-se como portadora de habilidades e espera a consideração do outro, frustrando-se muito quando não alcança esse objetivo. Volta-se para os animais e plantas na tentativa de não se decepcionar com a ausência de reconhecimento.

A árvore é frutífera, mas como a raiz não se fixa ao chão, ficando uma grande parte aparente, o potencial de desenvolvimento da paciente parece não lhe dar consistência para mobilizar-se no sentido de envolver-se com situações mais gratificantes para si, mantendo-se no lugar daquela que é explorada e humilhada. 


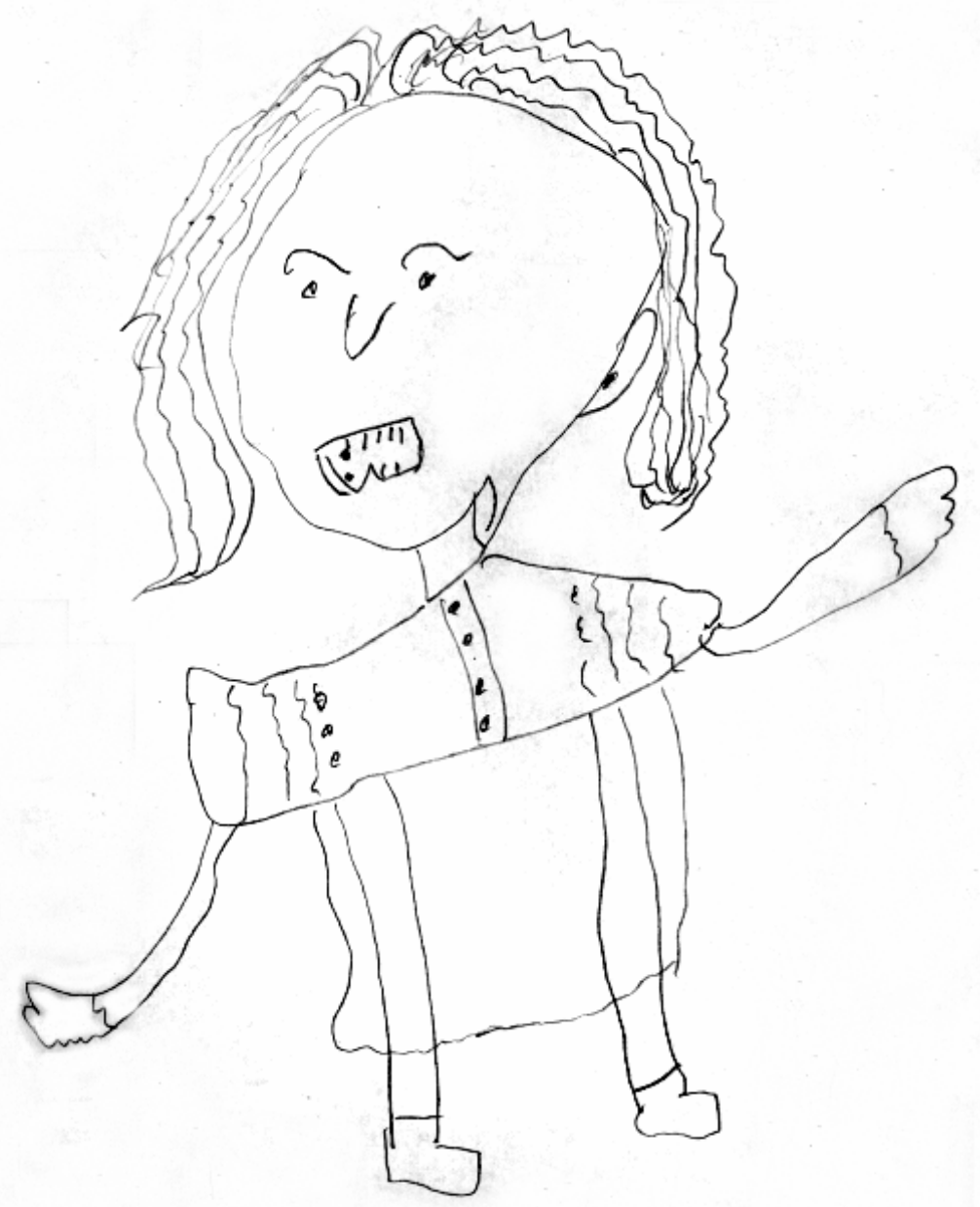

Fig. 7 


\section{Análise dinâmica do desenho da primeira pessoa:}

\section{Fig.7, p.82}

A ausência de linha de solo evidencia dificuldades no posicionamento decidido frente às circunstâncias ambientais. O desenho das mãos da primeira figura humana informa quanto ao comprometimento dos envolvimentos afetivo e interpessoal e os dentes aparecendo revelam muita hostilidade permeando as relações humanas.

As orelhas assinalam a desconfiança que parece caracterizar o envolvimento com o outro acarretando tensão nesse relacionamento.

A transparência no corpo é sugestiva de possível organicidade, o que pode acarretar em dificuldades de autocontrole.

\section{Associação ao desenho da primeira pessoa:}

“É a minha filha de 27 anos, a que mora comigo. Ela é revoltada, porque ela gostava mais do pai do que de mim e sabia que o pai me traia, talvez não aceitasse isso. Ela entra e sai de casa como se eu não existisse. Só se mete em encrenca, namora homens casados”.

\section{Análise da associação ao desenho da primeira figura humana:}

A associação ao desenho da primeira pessoa é pertinente ao que foi avaliado na análise do grafismo da primeira figura humana: muita hostilidade nas relações com a figura feminina. 


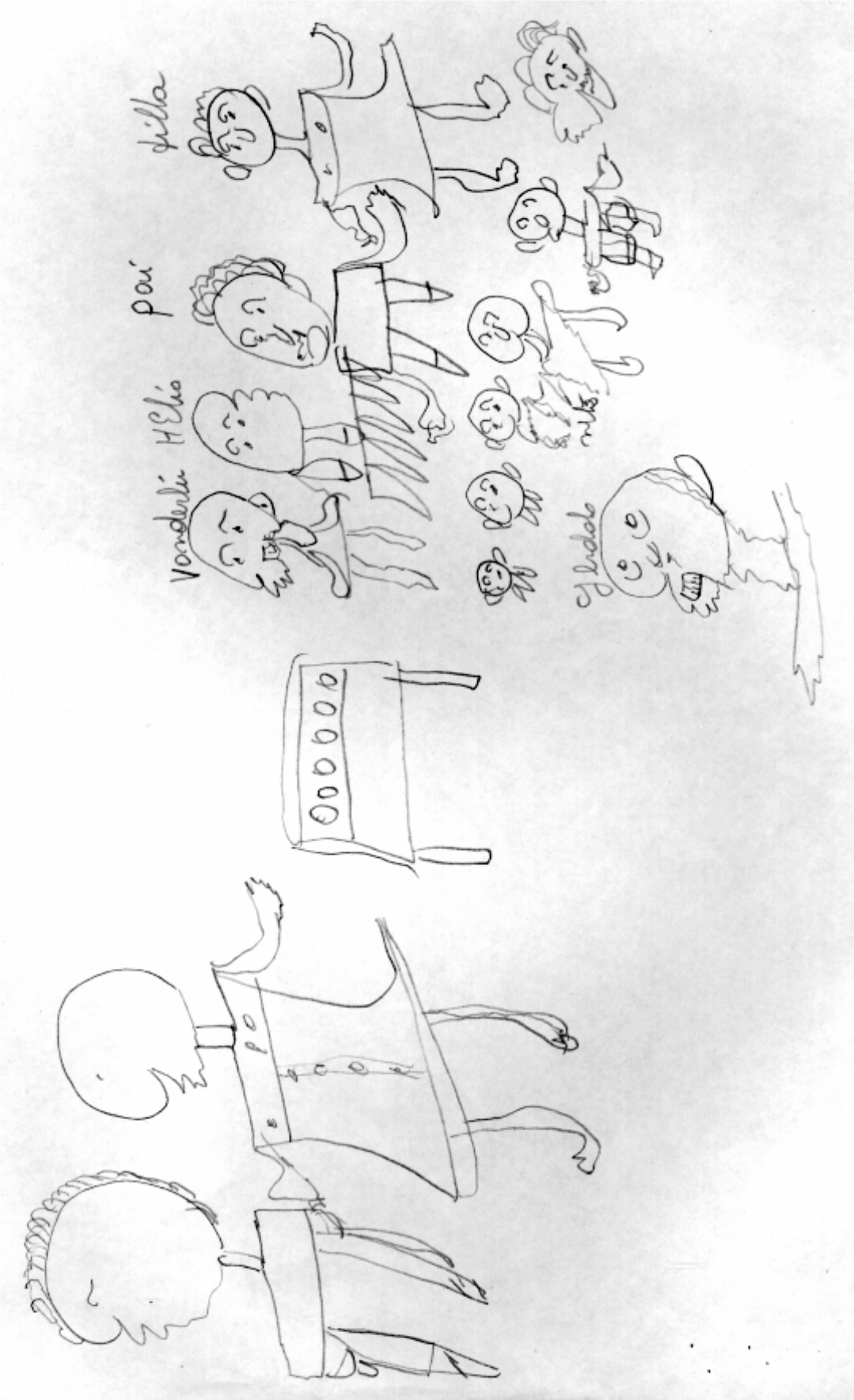

Fig.8 


\section{Análise do desenho da segunda figura humana:}

\section{Fig.8, p.84}

Novamente, as adições estão presentes como expressão da necessidade de agradar o outro com a sua produção. A expressão corporal muito prejudicada, mais uma vez denotando comprometimento na identidade. $O$ fogão aparece como o representante daquilo que a paciente tem a oferecer: fazer comida para muita gente. Alias, segundo a paciente, essa tarefa é a responsável pela sua dor nas costas. O casal parental é representado distante da família e separados pelo fogão. Pensando nessa disposição do desenho poderíamos pensar que o relacionamento afetivo é restrito e talvez possa ser substituído pela realização de tarefas, como fazer comida, por exemplo. É também possível de se supor que as realizações de tarefas adicionadas à falta de reconhecimento pelo o que é feito podem também causar dor, na medida que a remetem ao desamparo e solidão.

\section{Associação ao desenho da segunda pessoa:}

“É a festa do Ano Novo. Estão numa sala com filhos, netos, ouvindo música sertaneja e soltando fogos. Sabe todo final de ano eu ficava deprimida porque meu marido passava na rua com as amantes e voltava para casa bêbado. Aqui é como eu gostaria de passar as festas de final de ano, com a família. Nunca tive festa de Natal e nem de final de ano".

\section{Análise da associação ao desenho da segunda pessoa:}

A associação revela a decepção vivida no casamento devido a traições e uso de álcool pelo marido e a idealização de uma família unida.

\section{ENTREVISTA DEVOLUTIVA}

Psicóloga: Bom dia...

Paciente: (Interrompe) Achei que você havia me esquecido, apesar de você ter marcado o retorno no cartão quinze dias depois de eu ter terminado o teste. Demorou, gostava de vir aqui conversar, é bom falar da gente.

As coisas estão na mesma, minha filha com os namorados enrolados e eu não posso fazer nada. Na minha família cada um vive na sua, eu continuo não me conformando como os meus filhos não ligam para mim 
Psicóloga: A senhora tem alguma idéia por que eles não ligam?

Paciente: Acho que é porque sempre fui muito forte, trabalhei muito para criálos, pois o meu marido ficava na farra com a mulherada, então eu trabalhava bastante nas casas das patroas para sustentar todo mundo e acho que faltou carinho de mãe. Do pai não vinha nada mesmo: nem carinho e nem dinheiro, nada; e da mãe só vinha dinheiro e é claro que eu fazia o que eles gostavam de comer, mas carinho assim de pegar abraçar, beijar, isso não teve. Agora, hoje eles são grandes não pesam no sacrifício que eu fiz para criá-los. Acho que não mesmo, bem paciência porque eles não vão mudar (os olhos enchem-se de lágrimas).

Psicóloga: Hoje vou conversar com a senhora sobre o resultado da avaliação psicológica... (a paciente interrompe)

Paciente: É estou curiosa, para saber o que você vai falar de mim.

Psicóloga: Bem Dona Wilma, a senhora tem razão quando diz que o trabalho excessivo pode ter afastado os seus filhos, e como é sofrido para a senhora esse distanciamento (a paciente concorda com a cabeça). Mas esse não foi o único afastamento importante na sua vida...(paciente interrompe).

Paciente: Ah, não mesmo o mais difícil foi a morte do meu pai, minha vida piorou demais.(chora) Mudei de casa, praticamente perdi minha mãe também. Nossa foi duro demais (chora).

Psicóloga: Então Dona Wilma, como a senhora disse, a senhora era a predileta do seu pai, então com a sua morte, a senhora perdeu quem lhe acolhia, sentiu-se desamparada (paciente concorda e chora). A senhora foi para a casa da sua madrinha, pois era a que tinha melhores condições pessoais de suportar a mudança, apesar de ser criança.

Paciente: É verdade, ninguém pensou em mandar um irmão para me fazer companhia, fui sozinha. Minha mãe foi dura comigo.

Psicóloga: Depois a senhora parou de trabalhar porque seu marido ficou doente. Novo afastamento de algo que era importante para a senhora.

Paciente: Eu era querida pelas minhas patroas, fiquei triste quando não pude continuar trabalhando e para cuidar do meu marido que também nunca me respeitou.

Psicóloga: A senhora disse que sua mãe foi dura com a senhora, que o seu marido nunca lhe respeitou, mas não está percebendo que faz o mesmo consigo 
(paciente olha, parecendo estar surpresa). Veja quando a senhora operou, não pensou em solicitar uma readaptação na escola para não ter que mexer as panelas pesadas que lhe fazem mal à saúde. Agora os médicos, indicam tratamentos que podem ajudar muito na melhora da dor nas costas mais a senhora recusa-se a realizá-los, insistindo que quer a cirurgia. Os médicos indicam algo mais suave e a senhora pede algo mais intenso: a cirurgia. Talvez a senhora tenha aprendido ao longo do que já passou na vida que é essa a única forma de ser tratada, de ser querida. (paciente escuta atentamente e em alguns momentos acena com a cabeça concordando com o que está sendo dito).

Paciente: É a minha filha é um exemplo, não trabalha, me destrata e eu não sei o que faço com ela. Agora já não falo mais dos namorados, por que não adianta, ela só namora os casados.

Psicóloga: Pois é as experiências com a sua filha não são boas, com a sua mãe tambem não foi, o que faz com que a senhora sinta raiva de tudo o que elas lhe fizeram.

Paciente: É nada foi fácil, a minha madrinha tambem me explorou bastante e nunca me deu nada. Quando me casei ela me deu uma colcha branca bonita, mas não era aquela coisa, mas parecia que tava dando seda. Trabalhei muito na casa dela.

Psicóloga: A senhora falou que os seus filhos não vão mudar, mas a senhora pode mudar (paciente mostra-se atenta). Pode mudar o pensamento de achar que só é querida quando passa por situações duras na vida. O tratamento psicoterápico poderá ajudá-la a repensar o jeito da senhora viver.

Paciente: Onde é feito aqui mesmo no hospital?

Psicóloga: Sim, aqui na seção de Psicologia.

Paciente: Eu quero, foi bom conversar, a gente pensa em coisas que nem passam pela cabeça antes da gente falar com psicólogo.

Psicóloga: A senhora pensou no quê?

Paciente: Ah! Eu decidi que não vou mais falar com a minha filha dos namorados, porque assim ela não briga comigo. Isso eu pensei desde que estou vindo aqui. Eu quero sim fazer esse tratamento.

Psicóloga: Farei a sua inscrição e a senhora será convocada por telefone.

Paciente: Muito obrigado. 
Psicóloga: Até logo.

Paciente: Muito obrigado.

Psicóloga: Até logo.

\section{Integração dos dados do Psicodiagnóstico:}

A paciente refere que a sua dor nas costa relaciona-se ao excesso de trabalho tanto na escola onde mexe panelas cheias de comida quanto no casamento cuidando do marido inválido devido à esclerose múltipla.

Os modelos parentais de identificação foram precários comprometendo a identidade, o que pode ter acarretado alteração importante na autonomia. O déficit de padrões próprios de conduta parece ter contribuído para uma conduta submissa frente às exigências do mundo externo. A obediência acentuada a ordem externa garantiu a supressão, pelo menos em parte da carência afetiva, o que reforçou a manutenção dessa atitude.

Todavia, as decepções na relação com a mãe, no casamento e com os filhos foram superiores ao ganho de atenção que obtinha com a realização de atividades, acarretando em hostilidade na relação humana e conseqüentemente em seu desgaste.

A paciente evidencia dificuldade para envolver-se com situações que ajudariam a melhorar a sua condição de vida. Não se mobiliza para ser readaptada na escola permanecendo em uma função que lhe prejudica a saúde, fazendo uma atividade que exige esforço físico. Não consegue se aproximar dos filhos, em função de manter com eles um envolvimento de muito ressentimento, na medida em que eles não a valorizam. Denota uma relação de violência consigo, submetendo-se a envolvimentos e a circunstâncias de vida que lhe exploram como sendo o único jeito de sentir-se amada.

Ao longo dos dissabores que vivenciou sua atitude foi de passividade, não reagiu às perdas significativas que teve com revolta. Ao contrário parece ter passado pelas decepções com resignação acentuada. O comportamento bastante conformista de Vilma pode ter contribuído para uma alteração no movimento da libido, desencadeando o desenvolvimento do que Freud chamou de masoquismo moral.

No trabalho O Problema Econômico do Masoquismo (1924/1969, p.212), Freud salienta que: “a supressão de um instinto pode, com freqüência ou muito geralmente, resultar em um sentimento de culpa, e como a consciência de uma 
pessoa se torna mais severa e mais sensível, quanto mais se abstém da agressão contra os outros”.

Na entrevista devolutiva a paciente expressou que o excesso de trabalho prejudicou o envolvimento mais carinhoso com os filhos, e que essa seria uma das causas deles estarem afastados dela.

A ênfase no trabalho pode ter garantido a Vilma seu reconhecimento enquanto pessoa, aliviando assim o sofrimento originado pela morte do pai e na conseqüente separação da família de origem. Essa possibilidade de diminuição do sofrimento trouxe a Vilma a crença de que talvez essa fosse á única maneira de ser feliz, levando-a a intensificar a sua ligação com o trabalho em detrimento da relação afetiva.

Em nota de rodapé, de O Mal-Estar na Civilização, Freud ressalta:

"Nenhuma outra técnica para a conduta da vida prende o individuo tão firmemente à realidade quanto a ênfase concebida ao trabalho, pois este, pelo menos, fornece-lhe um lugar seguro numa parte da realidade, na comunidade humana. [...] A atividade profissional constitui fonte de satisfação especial, se for livremente escolhida, isto é, se, por meio de sublimação, tornar possível o uso de inclinações existentes, de impulsos instintivos persistentes ou constitucionalmente reforçados” (p.99).

Todavia, na mesma nota de rodapé, Freud alerta quantos aos riscos quando a busca da felicidade acontece com ênfase em apenas um tipo de conduta. Menciona que: "qualquer escolha levada a um extremo condena o individuo a ser exposto a perigos, que surgem caso uma técnica de viver, escolhida como exclusiva, se mostre inadequada” (103).

A morte do pai parece ter estabelecido o início do seu desamparo. Ela foi morar com a madrinha porque segundo sua mãe era a mais inteligente e então suportaria a separação da família. Na casa da madrinha trabalhou muito, possivelmente como uma forma de ser aceita e compensar o sofrimento pela morte do pai e distanciamento da família de origem.

Quando trabalhou como faxineira em casa de família pode ter resgatado o acolhimento na relação com as patroas. No entanto perdeu novamente essa relação de reconhecimento de sua pessoa, quando o marido adoeceu, remetendo-a mais uma vez ao desamparo. 
Assim sendo, a dor pode relacionar-se ao desamparo e solidão. O único jeito que pode ser amada é submetendo-se às relações humanas que a exploram com a sua capacidade para o trabalho, ou experimentando situações de vida muito sofridas. Nesse contexto, encontra na cirurgia uma forma de ser acolhida pelo médico, pelo hospital e pela equipe.

No entanto, as associações de todos os desenhos do H.T.P. com exceção do desenho da figura feminina (Fig.7, p.82), retratam a possibilidade de aproximação com os filhos, marcando a mobilização para o envolvimento com situações mais prazerosas.

No desenho da árvore (Fig.6, p.79) apesar da raiz estar aparente, a associação a esse grafismo evidencia o reconhecimento de si próprio, abrindo uma probabilidade de uma conduta mais suave para consigo.

Tanto o desenho quanto a associação ao desenho da figura feminina (Fig.7, p.82) retratam a hostilidade que permeia a relação da paciente com as mulheres, o que pode estar revelando a revolta com a sua mãe devido ao episódio de abandono e a traição ao pai. Tais experiências parece atualizarem-se no comportamento da filha, despertando em Wilma raiva, sentimento que sustenta uma relação de hostilidade mútua com essa filha.

No trabalho psicoterápico tais questões poderão ser tratadas, o que possibilitará à paciente elaborar o seu desamparo relacionado às figuras parentais, compreender que o sentido da sua dor refere-se aos maus tratos experimentados ao longo de sua vida, fazendo com que ela realmente acredite que a única forma de ser amada é através do sofrimento.

\section{Sujeito 3}

Paciente: Lílian (nome fictício), 50 anos, divorciada, tem dois filhos sendo o de 31 anos casado e o de 22 anos solteiro, reside com a paciente e é dependente químico. Trabalha como auxiliar de pesquisa no Instituto Butantã.

Histórico da hérnia de disco:

O diagnóstico de hérnia de disco foi em 1998 através de exame físico e ressonância magnética. Ficou um mês de licença médica fazendo uso de medicação 
para a dor. Retornou ao trabalho antes do término da licença, pois não agüentava ficar em casa. Passou a comer muito engordou e ficou deprimida.

Sentia fortes dores na perna direita que após algum tempo passou a atingir a perna esquerda.

No início de 2001 voltou a sentir dores nas costas devido à hernia de disco, novamente consultou a neurocirurgia sendo medicada e prescrito fisioterapia. No entanto, dessa vez a paciente tem insistido muito com os neurocirurgiões para ser operada, pois havia sido informada por outros pacientes que a cirurgia era eficaz na remissão da dor. Todavia, foi orientada a consultar-se na endocrinologia, pois estava acima do peso, o que acentuaria a dor lombar.

Nessa mesma época apresentou um quadro de depressão tratou-se na psiquiatria, fazendo uso de medicação antidepressiva durante todo o ano de 2001, recebendo alta do tratamento medicamentoso no final desse mesmo ano.

A paciente foi encaminhada para a seção de Psicologia, por solicitar demasiadamente a cirurgia, desconsiderando a prescrição médica quanto às consultas na endocrinologia e na fisiatria.

Segundo os neurocirurgiões, apesar da paciente ter hérnia de disco o que provoca dor, beneficiar-se-ia do tratamento fisioterápico e da medicação. Segundo os médicos não haveria indicação de cirurgia, uma vez que a hérnia é pequena, podendo-se tratá-la por outros procedimentos. Todavia, Lílian não toma o remédio, alegando não acreditar em sua eficácia, não quer fazer fisioterapia, devido a falta de tempo para esse último. Além disso, o excesso de peso contribui para acentuar a dor lombar.

\section{PRIMEIRA ENTREVISTA PSICOLÓGICA}

Psicóloga: Qual o motivo do seu encaminhamento à seção de Psicologia?

Paciente: Estou muito tensa devido aos problemas de relacionamento com o meu namorado. Acho que os aborrecimentos constantes com ele me deixam tensa e aí tenho dor nas costas. Quando o médico fez o encaminhamento para cá, eu achei desnecessário, mas depois pensei pode ser um jeito de encontrar o término do meu namoro.

Psicóloga: Que aborrecimentos têm no namoro? 
Paciente: Namoro um rapaz muito mais jovem do que eu há oito anos e foi a pior burrada que fiz na vida. Ele é funcionário do sítio da sua mãe, e quando o namoro começou, sua mãe alertou-a de que ela estaria procurando sarna para se coçar.

No início o relacionamento era bom, ele mostrava-se calmo. Porém com alguns meses de namoro, as discussões começaram devido a ciúmes dele. Ele faz escândalos na frente dos nossos amigos, chegando inclusive à agressão física. Hoje o namoro está péssimo, tento terminar mais ele diz que eu sou a mulher da vida dele, aí eu não consigo terminar, me faz bem para o ego escuta isso (chora).

Não conto nada para a minha mãe nem para os meus filhos o que acontece no meu namoro, mas percebo que os meus familiares não gostam dele, pois acreditam que ele queira se aproveitar da minha situação econômica.

Ele entra em sua casa a hora que quer, me agride com palavrões e fisicamente, não considera nada que eu fale no sentido de convencê-lo sobre o seu equivoco de achar que eu tenha outro homem.

O fato da minha mãe achar que ele quer o meu dinheiro está começando a fazer algum sentido. Minha mãe está bem financeiramente e é casada com uma pessoa que também está muito bem do ponto de vista financeiro, acho que isso chama a atenção dele. Aliás ele já pediu dinheiro emprestado para a minha mãe, $e$ como não pagou foi descontado no pagamento.

Psicóloga: Fale sobre o seu relacionamento com a sua mãe.

Paciente: É bom...(Pausa, respira fundo) é bom. Nós tínhamos uma família unida até o pai adoecer e falecer devido à problemática renal. Quando ele adoeceu minha mãe precisou cuidar da loja de roupas que era do pai e cuidar dos três filhos pequenos, sendo que eu era a mais velha e estava com quatro anos. Minha mãe decidiu que eu iria morar com o meu avô paterno, o que até hoje não aceitei. Até hoje não aceito isso, por que eu? E por que para a família do meu pai? Eles são frios, interesseiros, minha mãe mandava mantimentos e algum dinheiro para eles cuidarem de mim; a família da minha mãe é mais afetiva.

Quando eu me separei meus filhos eram pequenos e precisei matriculá-los período integral na escola, pois não tinha com que os deixar, mas fiquei com os dois, não mandei nenhum dos dois morar com parentes. O casamento terminou devido ao fato do meu marido começar a relacionar-se com outra mulher, fiquei triste já 
desconfiava, pois ele chegava tarde em casa e não tínhamos mais nada sexualmente há muito tempo, então né, já viu tem outra no pedaço. Ele mora com essa pessoa até hoje.

Bem, deixa eu te falar das minhas costas... Não sei por que os médicos não querem me operar. Tudo bem que eu estou acima do peso, mas não estou conseguindo emagrecer, então acho que a cirurgia tiraria a dor.

Tudo começou em 98, muita dor nas costas, nas pernas procurei o hospital fizeram ressonância magnética e constataram a hérnia de disco, fiquei de licença médica por um período de um mês, mas voltei antes pois comecei a comer demais engordei e fiquei deprimida. Não voltei mais porque não sentia dor.

Em 2001, parece que tudo aconteceu. As dores voltaram, eu engordei mais ainda, fiquei deprimida, fiz tratamento na psiquiatria com medicação, melhorei e tive alta no final do ano. Comecei tratamento na Endocrinologia, tomei remédio para segurar a boca, mas não adiantou muito, pois continuei a comer bastante e é claro que muito peso faz doer mais as costas.

Psicóloga: Lílian, o nosso tempo está terminado, até a próxima semana.

Paciente: Ok. Até lá.

\section{SEGUNDA ENTREVISTA PSICOLÓGICA}

Na segunda sessão, Lílian mostrou-se menos falante e parecia reflexiva.

Preciso falar uma coisa meu filho caçula está usando maconha. Descobri há pouco tempo, revolvendo o lixo achei um restinho da erva. Ele tem estado mais fechado no quarto, não conversa comigo, irrita-se com facilidade há bastante tempo, mas como eu ando muito absorvida pela relação com o meu namorado não posso estar mais próxima dele. Conversei com ele sobre o fato de ter achado maconha no lixo, e ele negou dizendo que aquilo não era maconha (pausa).

Estimulei ele a consultar-se na Psiquiatria, mas ele acha um absurdo, por que afirma com firmeza que não usa drogas. Acho que não posso fazer nada, vou trazêlo amarrado, à força para a consulta, nem vai adiantar. Enquanto isso ele vai se drogando, acho que estou com medo dele...(chora). Ele ficou revoltado quando eu falei do médico para ele. Não sei o que eu faço, para ajudá-lo. Na verdade acho que não posso fazer nada, já que ele não quer, uma vez que ele não usa drogas. 
O meu filho mais velho nunca me deu preocupação. (Pausa) Fez duas faculdades, é casado com uma excelente pessoa, e agora estão pensando em filhos. Sabe, tudo na vida desse filho é bem planejado. Em compensação, o caçula sempre foi bagunceiro com o material escolar, roupas e brinquedos.

O meu filho mais velho quer que eu more com ele, mas eu jamais poderia fazer isso, primeiro em função do caçula e também por causa do meu trabalho que eu adoro.

Trabalho há dez anos na sessão de pesquisa do Instituto Butantã. É muito bom trabalhar lá, me dou bem com todos, sou considerada a mãe da sessão. Levo bolos e tortas para tomarem café, sou muito querida pelos meus colegas.

\section{Análise das entrevistas psicológicas}

Os relacionamentos familiares e afetivos são insatisfatórios, decepcionando a paciente. Porém, evidencia dificuldade para terminar o relacionamento afetivo que apesar de ser marcado pela hostilidade, sente-se seduzida pelo fato de ser percebida como alguém importante para o namorado. Tal atitude nos faz pensar em prejuízo da sua auto-estima, aceitando relações afetivas que denigrem seu valor próprio, expondo-se a situações humilhantes.

A morte do pai acarretou em duplo sofrimento para a paciente. Um relacionado à perda do pai, o outro devido à mudança para a casa do avô paterno.

O dinheiro aparece como uma forma de comprar o carinho e a atenção do outro, o que evidencia relações afetivas precárias, bem como déficit importante na auto-estima.

Repete no namoro o que parece ter vivido na casa do avô paterno: um envolvimento mantido pelo dinheiro. Pensa em terminar o namoro, quando percebe o interesse do namorado pelo seu dinheiro e devido aos escândalos por ciúmes. No entanto, ao menor sinal de envolvimento afetivo, entrega-se à crença de que realmente, exista solidez afetiva nesse relacionamento.

Chama-nos a atenção o modo como a paciente reage diante das dificuldades do seu dia a dia. Em primeiro lugar, não aceita a conduta médica para tratar a hérnia de disco sem a intervenção cirúrgica. Inicia um namoro, apesar de ter sido alertada pela mãe sobre as dificuldades que essa relação poderia trazer-lhe. Constata as dificuldades mencionadas pela mãe e perpetua o namoro. Conscientiza-se de que seu 
filho caçula é dependente químico tenta ajudá-lo e não o consegue, na medida em que ele não aceita a ajuda.

Parece que ela tem atitude semelhante ao filho: afastar-se daquilo que a ajudaria, não se comprometendo com o tratamento, insistindo na cirurgia antes de fazer o acompanhamento médico.

A manutenção do sofrimento nos faz pensar em componentes masoquistas associados à culpa inconsciente provavelmente articuladas às fantasias edipicas. 


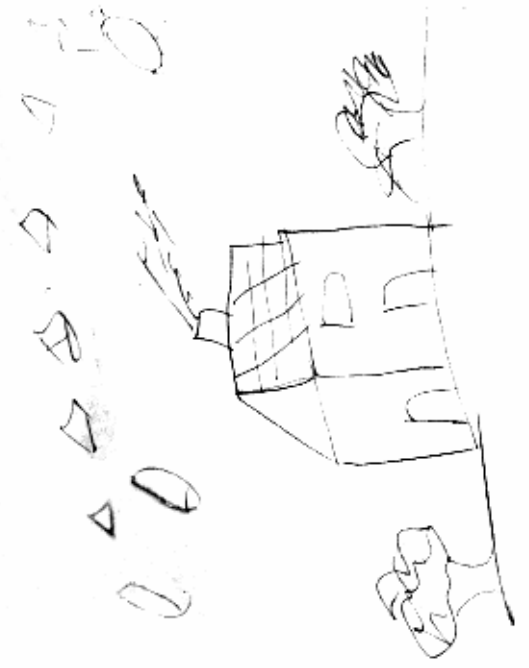

Fig.9 


\section{Análise dinâmica do desenho da casa:}

\section{Fig.9, p.96}

O desenho feito no quadrante superior esquerdo do papel representativo da subjetividade sugere relações familiares impulsivas sem preocupação com as conseqüências das ações. A simetria representada pelas árvores pode sinalizar a tentativa que a paciente fez para manter o equilíbrio emocional no âmbito familiar. Num contexto familiar onde a tônica é a subjetividade intensa, é possível de se supor que os relacionamentos sejam impulsivos, o autocontrole precário acarretando em desgaste importante do convívio familiar. Desse modo, a fumaça parece sinalizar conflito na dinâmica familiar.

A adição de elementos ao desenho da casa sugere carência afetiva com necessidade de suprir o outro na tentativa de ter a sua atenção.

\section{Associação ao desenho da casa:}

“Eu imagino que essa casa é uma casa de campo. Seria mais ou menos uma casa com um gramado na frente e atrás a piscina, nas laterais uma horta e um pomar. Só na imaginação, seria a minha casa de campo para um passar com os meus filhos e netos".

\section{Análise da associação ao desenho da casa:}

Idealização de um ambiente familiar tranqüilo e provedor bem como de um contato familiar afetuoso. 


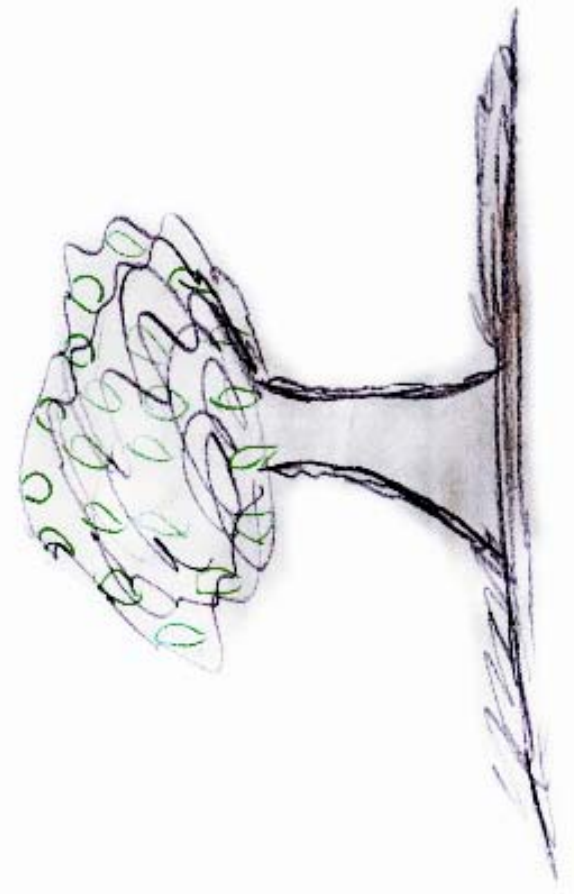

Fig.10 


\section{Análise dinâmica do desenho da árvore:}

\section{Fig.10, p.98}

Apesar da maior parte do desenho estar localizada no quadrante superior esquerdo do papel que representa ênfase na subjetividade, a base do desenho da árvore encontra-se no quadrante inferior esquerdo, com melhor condição de avaliar de modo mais objetivo as situações ambientais, o que garante um posicionamento mais adaptado às exigências das normas e valores sociais.

A presença de cor evidencia disponibilidade para o relacionamento afetivo, porém o predomínio da cor marrom inclusive na copa sugere que a preocupação com a produção é prioritária ao aspecto afetivo.

\section{Associação ao desenho da árvore:}

“Essa árvore eu imagino lá nessa casa que eu desenhei (referindo-se ao desenho da casa). Não sei o nome dela, mas é uma árvore que tem folhas verdes e brilhosas. Colocaria essa árvore beirando a entrada da casa que eu desenhei, para ficar mais bonita a entrada e a casa também”.

\section{Análise da associação ao desenho da árvore:}

Parece que a preocupação é tornar o ambiente familiar mais agradável. Retoma o desenho da casa o que parece revelar o quanto o convívio familiar a envolve e provavelmente, ela é quem tem a responsabilidade de melhorar o relacionamento familiar. 


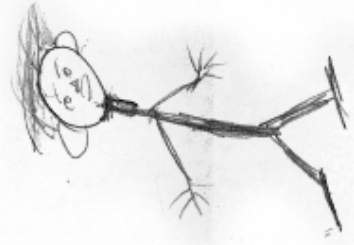

Fig.11 


\section{Análise dinâmica do desenho da primeira figura humana:}

\section{Fig.11, p.100}

A figura é do sexo masculino o quê parece indicar preferência pela figura paterna. Todavia, as características do desenho evidenciam contato hostil. O corpo frágil, bastante reprimido reflete ainda sinais de luto não elaborado.

As orelhas grandes responsáveis pelo nome da pessoa na associação ao desenho da figura humana denotam desconfiança no envolvimento com as figuras masculinas, bem como demonstram preocupação sobre o que é tido a respeito da figura masculina. Tal preocupação pode também trazer conflitos na sexualidade.

Os cabelos um pouco em desalinho, além de indicar Análise da associação ao desenho da primeira figura humana:utilização reduzida do potencial de iniciativa e decisão, revelam ainda algum conflito na área da sexualidade.

\section{Associação ao desenho da primeira pessoa:}

"É o Pinóquio por que é orelhudo, parece com um sobrinho meu. Ele está andando naquele caminho da casa com as árvores de folhas brilhosas”.

\section{Analise da Associação ao desenho da primeira pessoa:}

A associação referente ao desenho da casa, e o vínculo de parentesco com o personagem da estória, denotam mais uma vez o envolvimento intenso da paciente com a dinâmica familiar.

É interessante observar que na estória infantil o nome Pinóquio designa um boneco de pau de nariz grande. Na associação da paciente o que é grande são as orelhas, o que pode refletir conflitos na sexualidade provavelmente pela preocupação acentuada com o é dito e/ou percebido sobre a figura masculina.

A preocupação extrema com as opiniões a respeito da figura masculina pode remeter-nos ao raciocínio clínico voltado para a presença de questões edípicas que necessitariam ser esclarecida através de um trabalho psicoterápico. 


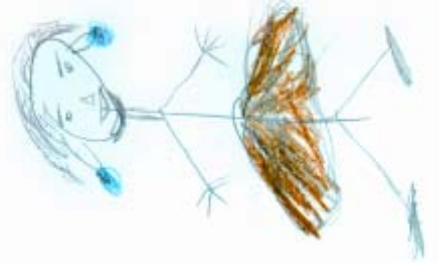

Fig.12 


\section{Análise dinâmica do desenho da segunda pessoa}

\section{Fig.12, p.102}

O corpo é desenhado de forma frágil e o contato é hostil. A cor laranja utilizada na saia é indicativa de muita mobilização voltada para a sexualidade o que traz a necessidade de controle repressor representado pelo acréscimo da cor preta na saia. A mistura cromática designa conflito na sexualidade.

O sombreado na região do queixo revela alteração na identidade pessoal o que associado com a ausência de linha de solo do desenho intensifica a dificuldade de se posicionar com determinação frente às exigências do cotidiano.

A ênfase nas orelhas através dos brincos pode ressaltar a preocupação sobre o que é dito a respeito de si próprio, assim como foi projetado no desenho da figura masculina por meio do personagem Pinóquio, gerando insegurança nas atitudes frente às situações ambientais.

A cor azul utilizada nos brincos denota um provável controle pela via racional das preocupações voltadas àquilo que possivelmente seria falado a seu respeito.

\section{Associação ao desenho da segunda pessoa:}

“Essa mulher aqui não tem nada haver com o menino do outro desenho. Ela é uma cangaceira do Nordeste e está dançando forró. Ela é muito doida, não vou falar mais nada desse desenho horrível. Ela está com saia laranja e brinco azul, tudo contrastando, não combina nada, é tudo doido”.

\section{Análise da associação ao desenho da segunda figura humana:}

A associação parece traduzir a ambigüidade da identidade representada pelo contraste na vestimenta e adornos bem como no adjetivo cangaceira que significa a presença de aspectos masculinos como soberanos na conduta feminina.

O esclarecimento quanto ao distanciamento entre a figura desenhada e o menino do outro desenho pode evidenciar o esforço da paciente para evitar o envolvimento com as situações familiares.

A desvalorização da figura feminina é bastante evidente, e parece relacionada aos conflitos de identidade e sexuais. 


\section{ENTREVISTA DEVOLUTIVA}

Psicóloga: Bom dia, Lílian, como tem passado?

Paciente: Mais ou menos (Sspira) ta difícil com o meu namorado. Ontem ele fez outro escândalo por ciúmes (Chora). Gostaria de terminar, mas não consigo. Entrou em casa, e só porque eu estava com uma blusa nova ele achou que eu estaria voltando de um encontro. Isso é um absurdo, mas não adianta tentar convencê-lo do contrário.

Psicóloga: Você pensa em algo que dificultasse o término do namoro?

Paciente: Bem, acho que a solidão, não gosto de ficar sozinha. Quando estamos bem, ele fala coisas que eu gosto. Diz que sou importante para ele, que sua a mulher da vida dele, então eu vou levando esse namoro. Não conto nada para ele sobre o meu caçula estar usando drogas, porque ele não está nem aí com os meus problemas. Então pensando bem eu já estou sozinha, mas não consigo terminar.

Psicóloga: Lílian, hoje estaremos conversando sobre os resultados da sua avaliação psicológica. Gostaria de começar pelo namoro.

Paciente: É o meu maior problema, vamos lá, pode falar.

Psicóloga: Você não consegue terminar o namoro, não consegue terminar algo que lhe aborrece, que lhe traz insatisfação, que lhe faz sofrer. A dor nas costas devido à hérnia de disco também lhe faz sofrer. Porém, terminar com essa dor parece-lhe mais fácil do que terminar com o namoro. Opera-se a hérnia e dor passa, no entanto, a mesma facilidade não acontece com o relacionamento afetivo: termina-se o namoro e pronto. Então a sua insistência por fazer a cirurgia pode estar relacionada com o termino que você gostaria de dar ao seu namoro. Veja, você não consegue cortar o namoro, que é o que você deseja, então insiste para cortar a hérnia de disco. Assim sendo não vai adiantar fazer a cirurgia, pois o que você deseja cortar da sua vida na verdade é o seu namoro.

Paciente: Parece reflexiva. É faz sentido, nossa! Não havia nunca pensado nisso. Que coisa, o que é a cabeça da gente.

Psicóloga: Um outro ponto que gostaria de conversar com você é relacionado à morte do seu pai.

Paciente: Ah! Sim. 
Psicóloga: Então, quando seu pai morreu você para a casa do seu avô paterno. A partir dessa situação, você formulou duas questões: por que você estaria indo e por que para a casa do seu avô?

Paciente: Bem, até hoje tenho essas perguntas na minha cabeça.

Psicóloga: Pois bem, essas questões parecem refletir a necessidade de você querer saber sobre a importância que você teria para a sua mãe, uma vez que a escolhida para ir morar longe dela foi você. Essa escolha pode ter despertado dúvidas quanto ao amor que a sua mãe teria por você. Nesse sentido, quando o seu namorado diz que você é a mulher da vida dele, ele responde qual é o seu lugar nesse namoro, o que de alguma forma supri a falta de resposta que você não teve da sua mãe. O esclarecimento dessa dúvida através da resposta do seu namorado pode estar dificultando o rompimento dessa relação.

Paciente: Entendo. Isso pode ser diferente?

Psicóloga: Sim, o tratamento psicoterápico, possibilitará você irá repensar sobre essas questões, o que ajudará a melhorar o seu posicionamento frente ao seu namoro, ao seu filho enfim frente às circunstâncias da sua vida.

\section{Integração dos dados do psicodiagnóstico:}

A paciente insiste em operar a hérnia de disco visando eliminar uma dor que é deslocada já no início da entrevista psicológica: a dor originária na relação com o namorado.

A dor mencionada pela paciente parece ter origem na dificuldade de cortar o relacionamento afetivo insatisfatório com o namorado, o que nos faz pensar que a castração conseqüência da resolução do Complexo de Édipo não foi possível de acontecer.

A morte do pai de Lilian ocorrida aos quatro anos de idade, exatamente no período em que o pai é o objeto preferido, escolhido pela menina, trouxe-lhe sofrimento ímpar. Após o falecimento do pai, ela vai morar na casa do avô paterno. Esperar-se-ia que a presença do avô pudesse substituir o pai, porém não é isso que acontece, dificultando a dissolução do Complexo de Édipo, mantendo Lílian aprisionada à imagem idealizada do pai.

Freud, em A Dissolução do Complexo de Édipo (1924/1969, p.221), afirma: 
A autoridade do pai ou dos pais é introjetada no ego e aí forma o núcleo do superego, que assume a severidade do pai e perpetua a proibição deste contra o incesto, defendendo assim o ego do retorno da catexia libidinal. As tendências libidinais pertencentes ao complexo de Édipo são em parte dessexualizadas e sublimadas (coisa que provavelmente acontece com toda transformação em uma identificação) e em parte são inibidas em seu objetivo e transformadas em impulsos de afeição.

A resolução do complexo de Édipo na menina possibilita que ela assuma o lugar da mãe e tenha uma atitude feminina com o pai. Essas possibilidades ainda são observadas em Lílian, na medida em que vivencia o período fálico.

Assim sendo o impedimento do processo de castração é o que não possibilita o corte na relação com o namorado, o que não a autoriza a ter para com o filho drogadicto uma atitude mais assertiva, o que acentua os aspectos masculinos no que se refere à agressividade em detrimento da identidade feminina, facilitando o seu reconhecimento como o personagem da historia infantil, Pinóquio que tem sua vida mantida pela figura de um pai idealizado.

Em O Ego e o Id (1923/1969, p.47), Freud ressalta:

A análise muito amiúde mostra que uma menininha, após ter de abandonar o pai como objeto de amor, colocará sua masculinidade em proeminência e identificar-se-á com seu pai (isto é, com o objeto que foi perdido), ao invés da mãe.

$\mathrm{Na}$ associação ao desenho da segunda figura humana (Fig.12, p.102) consegue pela primeira vez fazer um corte com a dinâmica familiar, despertando para uma possibilidade de individuação, mas ainda muito presa aos processos de identificação com o masculino, representado pela associação da cangaceira. A ênfase nos aspectos masculinos evidencia a não diferenciação entre sua auto imagem e o luto paterno. A nomeação dos aspectos femininos aparece no desenho de uma mulher enfeitada; no entanto, a caracterização é de uma mulher doida, que não combina nada com nada: não combina sexualidade feminina com a imagem que o contexto faz dela.

A insistência relacionada ao pedido para fazer a cirurgia de hérnia de disco retrata a necessidade de um corte que vem pela necessidade da castração. O médico representa a figura do pai bom idealizado que através do corte cirúrgico, a libertarlhe-á do sofrimento causado pela dor. O pedido da cirurgia equivalente ao pedido da castração visa o seu reconhecimento como ser de fato desejante, e não mais como um objeto de desejo de alguém. 
Com a morte do pai, a paciente formula duas questões: por que eu fui mandada para a casa do meu avô? E por que para a casa do meu avô? A primeira interrogação poderia ser entendida assim: Qual o lugar que eu tenho na vida dos meus pais?

O namorado responde a essa questão dizendo que ela é a mulher da vida dele, satisfazendo o desejo edipiano de ser a preferida pela figura masculina. Essa satisfação é ainda reforçada pelo fato do namorado pertencer à mãe, na medida em que é funcionário dessa, o que dificulta o corte na relação.

Quanto à segunda indagação pensaríamos na desconfiança dos homens. Maus tratos fazendo-nos pensar nos maus tratos que pode ter vivido na casa do avô, mesmo recebendo dinheiro da mãe. Portanto, a relação dinheiro e maus tratos estão juntos e é atualizada no namoro. Envolve-se com um homem de nível sócio econômico inferior ao seu e mesmo a perspectiva dele poder estar interessado apenas no dinheiro, não está garantindo um bom relacionamento.

A morte do pai parece ter sido o desencadeante da dor psíquica de Lílian. O objeto perdido, no caso seu pai, instalou-se dentro do ego da paciente, estabelecendo as diretrizes para a instalação do distúrbio da melancolia.

Freud, em Luto e Melancolia (1917[1915])/1969. p.281), considera:

Existem, num dado momento, uma escolha objetal, uma ligação da libido a uma pessoa particular; então, devido a uma real desconsideração ou desapontamento proveniente da pessoa amada, a relação objetal foi destroçada. O resultado não foi o normal - uma retirada da libido desse objeto e um deslocamento de mesma para um novo -, mas algo diferente, para cuja ocorrência várias condições parecem ser necessárias. A catexia objetal provou ter pouco poder de resistência e foi liquidada. Mas a libido livre não foi deslocada para outro objeto; foi retirada para o ego. Ali, contudo, não foi empregada de maneira não especificada, mas serviu para estabelecer uma identificação do ego com o objeto abandonado.

Nos desenhos da casa (Fig.9, p.96) e da figura masculina (Fig.11, p.100) não têm cor, possivelmente caracterizando a tristeza pela ausência paterna. A morte do pai prejudicou de modo significativo o desenvolvimento da paciente, principalmente por estar vivenciando a fase edipiana. Assim sendo, necessita elaborar essa perda, para que possa se apropriar, de fato, de sua identidade feminina. 


\section{Discussão dos Resultados}

Freud, em Tratamento Psíquico (ou mental) (1905/1969, p.22), enfatiza que “as palavras são o instrumento essencial no tratamento mental”. Hammer (1969, p.51) considera: "los dibujos igual que el lenguaje simbólico alcanzan las capas primitivas del sujeto".

O significado simbólico apreendido pelas comunicações oral e gráfica permite a identificação e a compreensão dos aspectos intrapsíquicos, que pautam os mais variados comportamentos do paciente frente à doença e o seu tratamento.

Freud e Hammer compartilham a mesma idéia quanto à importância das associações livres enquanto vias de acesso aos conteúdos inconscientes. A compreensão do simbolismo implícito nas associações livres permite o conhecimento do mecanismo responsável pela qualidade da articulação entre a estrutura e o dinamismo psíquico, ressaltando fatores como: ordens imperiosas do superego sobre o ego, sentimento de culpa acentuado que obstrui o desenvolvimento egóico, perdas importantes comprometendo a auto estima do paciente, enfim falamos da complexidade do aparelho psíquico e da sua participação num universo de sintomas apresentado pelo paciente do qual selecionamos a dor.

Iniciando a discussão dos resultados ressaltamos que um dos pontos em comum às pacientes que constituíram a amostra dessa tese foi a condição de estabelecerem relações entre a dor nas costas e a sua história de vida. Foram unânimes em perceber a influência das preocupações intensas, das decepções nos relacionamentos familiares e afetivos, da perda de alguém, como fatores importantes na manifestação dolorosa.

Essa condição dá às pacientes a oportunidade de refletirem quanto à existência de outras fontes da sintomatologia dolorosa, afastando-as do campo exclusivamente físico como resposta à dor nas costas devido à hérnia de disco. 
A disponibilidade de todas as pacientes associarem livremente durante o processo de psicodiagnóstico sinaliza que o início do trabalho foi marcado pela transferência positiva.

Freud, em Recordar, Repetir e Elaborar (Novas Recomendações sobre a Técnica da Psicanálise II) (1914/1969, pp.197-198), menciona que:

Se o paciente começa o tratamento sob os auspícios de uma transferência positiva branda e impronunciada, ela lhe torna possível, de inicio, desenterrar suas lembranças tal como o faria sob hipnose [...].

Tomando-se como ponto de partida a transferência positiva estabelecida e mantida pelas pacientes, diríamos que começamos bem e que caminharemos por um terreno promissor durante a discussão dos resultados dessa tese.

Todas as pacientes perderam um dos componentes do casal parental, quando eram crianças. A mãe de Martha morreu quando a paciente estava com nove anos de idade e Vilma e Lílian perderam o pai quando estavam respectivamente com nove e quatro anos de idade.

Outro ponto comum entre as pacientes é que a orfandade de um dos pais provocou mudanças significativas em suas vidas. Uma das mudanças referiu-se à separação delas do contexto familiar de origem.

Em Recordar, Repetir e Elaborar (Novas Recomendações sobre a Técnica da Psicanálise II) (1914/1969, p.198), Freud esclarece:

O paciente repete ao invés de recordar e repete sob as condições da resistência. [...] Repete tudo o que já avançou a partir das fontes do reprimido para sua personalidade manifesta - suas inibições, suas atitudes inúteis e seus traços patológicos de caráter.

O sofrimento devido à morte de um dos pais é revivido nas situações atuais de vida, de cada paciente que constitui a amostra desta tese de doutorado.

No material clínico de Martha, as sucessivas perdas de figuras femininas: mãe, tia e avó materna lançaram-na ao sofrimento do convívio com o pai, por quem foi bastante hostilizada. Essa vivência desagradável é revivida com o medo de perder as filhas, perda de figuras femininas tão importante quanto foi a perda de sua mãe. A adoção da sobrinha parece uma tentativa de evitar o seu sofrimento pela ausência da figura materna. 
No caso de Vilma, a morte do pai seguida do abandono da mãe submeteu-a a hostilidade da madrinha. A doença do marido privou-a, mais uma vez, da atenção da figura feminina que havia resgatado no trabalho enquanto doméstica em casa de família. A repetição do desamparo causado pelo distanciamento da mãe acontece no afastamento dos filhos.

A paciente Lílian, também foi separada da mãe após a morte do pai. A ausência da mãe foi substituída pelo dinheiro como uma garantia de convivência satisfatória com a figura masculina. O fracasso dessa parceria é repetido no namoro, onde o interesse do namorado pela condição financeira da paciente, não garante um envolvimento afetivo satisfatório.

A ausência de uma das figuras parentais remeteu essas pacientes ao desamparo e uma das conseqüências desse sentimento equivaleu à vivência traumática.

Conforme Freud, em Além do Principio do Prazer (1920/1969, p.45), a vivência traumática se caracteriza por:

Quaisquer excitações provindas de fora que sejam suficientemente poderosas para atravessar o escudo protetor. [...] Um acontecimento como um trauma externo está destinado a provocar um distúrbio em grande escala no funcionamento da energia do organismo e a colocar em movimento todas as medidas defensivas possíveis.

A mente reage a esse excesso de excitação convocando energia catéxica de todos os lados visando fornecer altas catexias no lugar da ruptura.

A perda de alguém querido constitui-se em um excesso de excitação, ocasionando um superinvestimento na representação psíquica dessa pessoa que foi perdida. Esse superinvestimento afetivo da imagem do objeto perdido causa o desprazer, na medida em que sentimos saudades toda vez que escutamos uma música, olhamos um objeto, enfim qualquer fator que desperte a lembrança da pessoa que agora está ausente. A tensão gerada por tais lembranças é o desprazer e a descarga parcial dessa tensão caracteriza o prazer.

Nasio (1997, p.36) considera que "um certo grau de insatisfação é vital para conservamos a nossa consistência psíquica”. A afirmação de Nasio se refere ao movimento das pulsões no aparelho psíquico, importante na compreensão da subjetividade da dor.

Diante da perda de alguém muito estimado uma parte das pulsões não se liga à imagem do objeto perdido e se volta com violência contra a organização 
intrapsíquica, ocasionando um movimento caótico, porém silencioso característico da pulsão de morte, provocando a dor psíquica.

Voltando aos casos clínicos temos que o convívio freqüente com situações de sofrimento pelo qual Martha passou, o voltar-se intensamente para saciar o outro em detrimento de si próprio evidenciado por Vilma e a submissão de Lílian aos maus tratos do namorado parecem relacionar-se às respostas que as pacientes foram encontrando para a estimulação caótica da pulsão de morte. A movimentação silenciosa desse montante pulsional, desvinculada das representações dos objetos perdidos, remeteu as pacientes ao sofrimento imprimido pela dor psíquica e cada uma diante desse processo doloroso, manifestou de maneira unânime a única forma como esse caos é expresso: pela via do somático.

Assim sendo, as constantes queixas de dor nas costas das pacientes bem como as suas solicitações insistentes para a realização de cirurgia caracterizam a maneira peculiar com que a pulsão de morte se faz presente na vida dessas pessoas.

Todavia, a sensibilidade do neurocirurgião às queixas das pacientes culminando com o seu encaminhamento à seção de Psicologia, possibilitou que por meio do psicodiagnóstico elas pudessem expressar oral e graficamente as associações livres tornando ruidoso o que até então se mantinha silencioso e empurrando cada vez mais as pacientes para solicitarem condutas invasivas ao seu corpo, visando aliviar uma dor, que só pode ser abrandada mediante a elaboração das questões intrapsíquicas envolvidas na sintomatologia dolorosa.

A dor pela perda do objeto de amor fez com que cada uma reagisse numa tentativa de resgatá-lo. Todas as pacientes, como já foi mencionado, têm em sua historia de vida perdas significativas, as quais foram tentando administrar; e diríamos que apesar de terem se esforçado, a administração foi falha e o sinal desse déficit administrativo é a dor.

Falamos de um processo doloroso fruto da violência com que a pulsão de morte irrompeu em suas organizações psíquicas, desestabilizando o equilíbrio psíquico imprimindo ao eu sofrimento intenso.

Desse modo, a solicitação insistente para fazerem a cirurgia reflete a perpetuação do sofrimento, mediante solicitação de condutas médicas invasivas ao corpo. 
Os casos clínicos convergem para o distanciamento da mãe ou por morte ou pelo seu abandono estabelecendo a convivência das pacientes com situações desagradáveis e por vezes hostis.

A hérnia de disco provoca dor física, mas, o modo pelo qual as pacientes procuram suavizá-la evidenciam a demanda dos fatores intrapsíquicos, protagonistas da dor psíquica, sendo o superinvestimento das figuras parentais perdidas feito pelas pacientes, um dos fatores responsáveis por esse processo doloroso. $\mathrm{O}$ excesso de investimento no objeto de amor perdido comprometeu a elaboração do seu luto, abrindo caminho para uma reação melancólica, o que comprometeu a auto estima de todas as pacientes.

No H.T.P. é também possível verificarmos sinais indicativos da vivência do desamparo originado no meio familiar.

Nos desenhos da casa de todas as pacientes (Fig.1, p.58; Fig.5, p.76; Fig.9, p.96) o acesso é dificultado por não ter linha de solo e caminhos e escadas que finalizam em paredes. $\mathrm{O}$ acesso ao convívio familiar é ainda prejudicado devido à localização do desenho no quadrante do papel superior esquerdo característico de uma tendência egocêntrica, tornando a convivência familiar inacessível.

Todas as pacientes em suas associações ao desenho da casa manifestaram sua história de vida marcada pelo distanciamento da figura materna. As associações se referem ainda à ausência da mãe vivenciada na infância e a idealização de união familiar principalmente entre filhos e a mãe.

Quanto ao desenho da árvore nota-se a presença da linha de solo em todos os desenhos, o que demonstra condição de um posicionamento próprio mais determinado frente às exigências do mundo externo, apesar do sofrimento que é expresso no grafismo sob a forma de um traçado repetitivo de 'ir e voltar' na base e no tronco da árvore, bem como, de marcas sugestivas de angústia ao longo do tronco (Fig.2, p.61; Fig.6, p.79;Fig.10, p.98).

A presença de linha de solo nos desenhos da árvore (Fig.2, p.61; Fig.6, p.79) e a sua ausência nos desenhos da casa de Martha e Vilma (Fig.1, p.58; Fig.5, p.76) bem como a presença da linha de solo no grafismo da árvore da Lílian (Fig.10, p.98), porém feito em um quadrante onde a soberania é da subjetividade, dificultando, assim o comportamento mais decidido, denotam que essas pacientes possuem 
recursos psíquicos que as auxiliarão na elaboração da dor causada pela perda do objeto de amor.

Nas figuras humanas do H.T.P. se observa a ausência da linha de solo tornando as pacientes vulneráveis a qualquer tipo de estimulação vinda do mundo externo. Por outro lado, as mãos não facilitam o contato interpessoal, o que pode estar significando uma tentativa de se resguardarem do espectro bastante amplo e precário enquanto discernimento daquilo que é absorvido do meio ambiente (Fig.3, p.64; Fig.4, p.66; Fig.7, p.82; Fig.8, p.84; Fig.11, p.100; Fig.12, p.102).

As associações aos desenhos das figuras humanas revelam a crença em relacionamentos melhores na medida em que trazem a esperança de resgatar o que não lhes foi possível ter na infância, o acolhimento do núcleo familiar.

As pacientes se assemelham na solicitação insistente para fazer a cirurgia de hérnia de disco visando cessar a dor. Por mais que os médicos prescrevessem outras formas de tratar a dor, para essas pacientes só existia uma: aquela onde haveria o corte cirúrgico.

Falamos então de um corte cujo objetivo é o alivio da dor, é a transformação do desprazer sempre em um incompleto prazer.

De qual corte estamos falando? A resposta relaciona-se ao corte no movimento caótico e silencioso da pulsão de morte responsável por lançar as pacientes na ciranda masoquista, incrementando os sentimentos de culpa, proporcionado a continuidade da dor mantendo-se o círculo vicioso do sofrimento - compulsão à repetição - que parece ter se instalado em épocas muito precoces da vida de cada uma dessas pacientes.

Na medida em que a dor trazida pelas pacientes que compõem a amostra dessa tese se faz pela ordem do psiquismo o que necessita ser cortado se relaciona à maneira como cada uma reagiu à ausência do objeto de amor e também à falta do seu amor.

No relato e na produção gráfica de Martha, Deus representa a idealização da figura paterna, que resolverá todos os seus problemas. Martha identifica o médico à imagem divina, representada pelo Grande Pai, entendendo que por meio do corte cirúrgico ele cortar-lhe-á a angústia pela ameaça de perder as filhas.

Com relação à paciente Vilma o sofrimento originado pela morte do pai, pode ter sido compensado pela ênfase no trabalho por meio do qual ela conseguiu ser 
reconhecida enquanto pessoa. A dor conseqüência do desamparo pela morte do pai foi então, aliviada pelo excesso de trabalho, que lhe custou o afastamento afetivo tanto no envolvimento com o outro quanto com as mais variadas situações ambientais.

Após a morte do pai, Vilma foi abandonada pela mãe, foi desnutrida do carinho materno. Na entrevista Vilma menciona com precisão que com 12 anos de idade já cozinhava na casa da madrinha e hoje ela é cozinheira de uma creche. A questão que se faz é com que condição uma pessoa que não foi nutrida conseguiria nutrir? A resposta pode estar na dor, pela submissão às circunstâncias de vida tão desagradáveis e danosas pelas quais Vilma suportou e vem suportando por acreditar ser esse o único jeito de ser nutrida e reconhecida.

O crédito de que a passividade frente ao acúmulo de solicitações acompanhado de distanciamento afetivo seria a garantia de valorização de sua pessoa foi também encontrada em todos os seus desenhos do H.T.P., uma vez que se caracterizaram pela quantidade de adições e foram os únicos totalmente acromáticos da amostra (Fig.5, p.76; Fig.6, p.79; Fig7, p.82;Fig.8, p.84).

No desenho da segunda pessoa (Fig.8, p.84), Vilma faz uma família reunida na festa de Ano Novo. O fogão separa o casal parental dos demais familiares, o que pode representar o corte da família de origem que a paciente teve após a morte do pai. A imagem do fogão sugere ainda a dificuldade para nutrir na medida em que esse é desenhado sem sinal algum de alimento.

Assim sendo, a insistência em ser operada traduz-se na maneira desagradável e que Vilma entende ser acolhida e nutrida pelo médico, pela instituição hospitalar e pela equipe multidisciplinar.

A paciente Lílian perdeu o pai aos quatro anos de idade e assim como Vilma foi abandonada pela mãe, após o falecimento do seu pai.

A tentativa da mãe de Lílian em substituir sua ausência pelo dinheiro fracassou, pois a paciente experimentou situações desagradáveis no convívio com o avô paterno, apesar de sua mãe enviar-lhe dinheiro para cuidar da neta. O relacionamento com o avô foi difícil, segundo a paciente, por se tratar de alguém muito frio do ponto de vista afetivo. 
O namoro de Lílian assemelha-se ao relacionamento com o avô paterno, uma vez que, apesar de gozar de uma boa condição econômica, esse fato não lhe garante um relacionamento afetivo satisfatório com o namorado.

A dificuldade em cortar o namoro acontece devido ao rapaz sinalizar o quanto ela é importante para ele. Tal afirmação responde a dúvida que Lílian tem quanto ao lugar que ela ocupa na vida da sua mãe, devido ao fato de ter sido precocemente separada de sua mãe, por decisão dessa última. A preocupação em ter essa questão solucionada, é a responsável pela continuidade desse envolvimento afetivo.

Assim sendo, busca pela cirurgia, cortar a relação afetiva que não consegue fazer devido às questões expostas anteriormente.

A ausência de cor nos desenhos da casa (Fig.9, p.96) e da primeira pessoa (Fig.11, p.100) do H.T.P., acrescido do sombreamento do corpo do homem sugerem tristeza no convívio familiar e luto possivelmente relacionada à morte do pai.

As associações aos desenhos que se seguem ao da casa relacionam-se ao desenho dessa, com exceção do desenho da segunda figura humana. A manutenção da casa como o eixo principal das associações aos outros desenhos parece sinalizar a hegemonia da tristeza e do luto na vida de Lílian.

Em contrapartida, os desenhos da árvore (Fig.10, p.98) e da segunda figura humana (Fig.12, p.102) do H.T.P. são coloridos denotando uma articulação mais afetiva com os próprios objetivos. Na associação ao segundo desenho, Lílian faz questão de mencionar que essa em nada se refere ao desenho da primeira figura humana, marcando assim um corte com o sofrimento e um indicio de compreensão da ausência do pai, até então não aceita.

A partir do momento em que consegue essa distância, as sua habilidades são expostas, surgindo uma mulher com atributos femininos apesar de ainda se encontrar identificada com a imagem do pai idealizado. A representação idealizada da figura paterna se faz presente na ambivalência quanto a sua identidade: ora os adornos ressaltam os atributos femininos, ora a denominação 'cangaceira' reitera o predomínio das características masculinas sobre as femininas.

A disponibilidade para o atendimento na seção de Psicologia apresentada por Martha e Lílian e a mudança de atitude da Vilma passando a ver um sentido no seu encaminhamento à Psicologia e o interesse das três na entrevista devolutiva, aceitando o atendimento psicoterápico, sinalizam um prognóstico otimista quanto à 
possibilidade de reverem os constantes pedidos de cirurgia, uma vez que o que precisam cortar não se faz pelo corte cirúrgico, mas sim pelo tratamento psicoterápico. 


\section{Considerações Finais}

“Cada dor é uma dor de uma pessoa, com todas as suas peculiaridades...”

(Carvalho)

Ao longo das leituras realizadas para a elaboração desse trabalho fui tomando consciência de algo que até então não me era suficientemente claro, refiro-me ao fato do tema dor não ser abordado com a freqüência que havia imaginado. A literatura não dispõe de muitos títulos e mesmo nos escritos de Freud não se tem muito sobre a dor.

Psicanalistas como Berlinck, Nasio e Garcia-Roza, bem como profissionais de outras abordagens teóricas, compartilham o que pude constatar durante o tempo em que estive estudando sobre o assunto, os trabalhos sobre dor são ainda em pequeno número.

O objetivo desta tese foi compreender as razões pelas quais pacientes portadoras de hérnia de disco insistem com os médicos para serem novamente operadas ou abdicam dos procedimentos prescritos para solicitarem apenas a cirurgia.

A reiteração no pedido para serem operadas desconsidera completamente as justificativas médicas para não fazer a cirurgia. As pacientes pedem, pedem de novo, não diversificam a forma de pedir e não são atendidas. A freqüência com que solicitam a cirurgia revela que a dor é constante, preenchendo de modo quase pleno a vida dessas pessoas.

Não aceitam remédios, fisioterapia, acupuntura, hidroginástica enfim qualquer procedimento que pudesse aliviar o sintoma doloroso, pois na concepção dessas pacientes a dor é finalizada com o corte cirúrgico. Há que se cortar o corpo e tirar o está causando a dor. Já que é assim, por que os neurocirurgiões não operam? 
A resposta médica é que não há indicação, uma vez que o tamanho da hérnia de disco é pequena; as pacientes, todavia, pensam completamente diferente e por isso querem a operação.

Bem, se a cirurgia está fora das perspectivas de tratamento dessas pacientes, o que fazer? Cabe entendermos de que dor essas pacientes falam e o que necessita ser cortado, eliminado da vida dessas pacientes, para que a dor cesse.

A dor mencionada pelas pacientes se refere à dor psíquica e por meio do psicodiagnóstico pudemos entender a sua origem o seu desenvolvimento e como as pacientes foram compondo suas vidas em função desse processo doloroso.

O material clínico obtido no Psicodiagnóstico revelou que a origem da dor psíquica dessas pacientes referiu-se à perda de um dos componentes do casal parental, gerando no momento acentuada dor, marcada pelo inconformismo do que estava sendo vivido.

Perder pai e/ou mãe na infância já é por si muito doloroso, portanto, se a esse sofrimento ainda for acrescido o distanciamento da família a dor é sem dúvida intensificada.

Todas as pacientes foram distanciadas do convívio familiar após a morte de um dos pais, quando estavam com quatro e nove anos de idade, sendo que, até hoje não compreenderam a razão desse afastamento familiar, apesar de terem sido informadas sobre o motivo de tal decisão.

Berlinck (1998, p.75) considera o homem como componente de uma espécie 'dolorosa', sentimento originado nas perdas significativas, estimulando interesse constante em sua busca desequilibrando o aparelho psíquico.

A maneira como o ser humano se mobiliza para encontrar a pessoa importante para si, de quem, em virtude das vicissitudes da vida, foi privado do seu relacionamento é determinante no significado da dor.

O entendimento da articulação: perda de quem se ama e o modo como o seu resgate se sucede é fundamental para decifrarmos o sentido da dor na vida de cada um.

O hospital é o lugar onde encontramos uma grande concentração de sofrimento humano. Possivelmente, o índice de sofrimento encontrado em um hospital só deve ser inferior ao daqueles que por alguma razão não podem usufruir dos recursos da 
instituição hospitalar, e ao daqueles que padecem com a ação devastadora das guerras.

Se por um lado, o hospital é onde encontramos uma porcentagem alta de dor, por outro é também o local onde essa dor é tratada. Nesse sentido, há que se diferenciar quanto às características implícitas no processo doloroso, para estabelecermos as condutas mais eficientes no seu tratamento.

O médico tenderá a considerar a dor do paciente sob a ótica do desconforto físico provocado por lesão de algum órgão, por processos inflamatórios e/ou infecciosos, por formações tumorais, enfim a tônica cairá no soma.

Sorrateira, porém, constante e raramente percebida se encontra a dor psíquica, ocasionada pela perda de pessoas queridas. Se já não bastasse o sofrimento advindo dessa ausência, os caminhos que levam as pessoas a encontrar o que perderam são por vezes danosos acentuando a dor.

A dor psíquica tem sua origem na amargura, na tristeza, na revolta, no inconformismo que a falta do outro faz, arremessando o paciente para o domínio da pulsão de morte, que de forma avassaladora, propicia solicitações que culminam com ações para tratar a dor onde o corpo será cortado, mutilado, invadido, enfim submetido a maus tratos desnecessários.

A dor psíquica não é tratada com analgésicos, mas sim com tratamento psicoterápico oferecendo à pessoa a possibilidade de falar sobre suas experiências ao longo da vida.

O psicólogo, por meio de uma escuta diferenciada, permite que os aspectos intrapsíquicos até então emudecidos se tornem ruidosos e, portanto, representados no aparelho psíquico, garantindo assim sua elaboração com conseqüente alivio da dor.

O serviço da Neurocirurgia do H.S.P.E. se mostrou preocupado com a atitude insistente de determinadas pacientes para serem submetidas à cirurgia de coluna devido à hérnia de disco.

Na medida em que a hérnia de disco estava pequena, não havia razão física que justificasse o pedido de cirurgia feito pelas pacientes, visando tratar a dor que segundo as pacientes era intensa. As queixas constantes de dor, associadas às solicitações para operar, sem que o houvesse aumento da hérnia de disco, chamaram a atenção dos médicos para as questões mentais que poderiam estar relacionadas às queixas dolorosas. 
O organismo humano e o aparelho psíquico fazem parte de um todo indissolúvel, assim sendo, é importante a atenção do médico para o pólo mente, da díade mente-corpo, uma vez que procedimentos utilizados no tratamento da dor podem ser evitados, pois serão insuficientes para aliviá-la, já que a sua origem não é apenas somática.

O esclarecimento às pacientes sobre os componentes intrapsíquicos presentes no sintoma doloroso identificados por meio do Psicodiagnóstico permitiu a aceitação do tratamento psicoterápico, na medida em que lhes foi possível compreender as razões mentais implícitas na crença absoluta de que o único procedimento capaz de tratar a dor da qual eram vítimas, far-se-ia pela cirurgia.

A condição de entenderem que o corte da dor seria feito pelo processo psicoterápico e não pelo procedimento cirúrgico, parece sinalizar que os objetivos propostos por esta tese de doutorado foram atingidos.

Todavia, muito ainda precisa ser feito no sentido de sensibilizar os profissionais da área da saúde e principalmente os médicos a atentarem para as questões mentais, sempre presentes em qualquer sintoma físico. Há que se considerar o fato de que algumas estruturas psíquicas, como, por exemplo, o masoquismo, submete os pacientes a penitências cruéis e sem que percebam os médicos podem ser agentes facilitadores dessa demanda punitiva.

Desse modo, esperamos que esta tese possa contribuir para uma reflexão sobre a temática dor e, principalmente, assinalar o quanto a influência da historia de vida e das características psíquicas têm com a sua intensidade e a maneira como os pacientes se mobilizam para suavizá-la, sendo que a somatória dessas variáveis parece indicar possíveis significados da dor para cada um. 


\section{Referências Bibliográficas}

ALLPORT, G.W. e Vernon, P.E., Studies in Expressive Movement. In: Hammer, E. F. Testes Projectivos Graficos, Buenos Aires: Paidós, 1969, p.52.

AMARAL, A., Lombalgia na Síndrome Pós-Laminectomia. In: Simbidor. Arquivos do $5^{\circ}$. Simpósio Brasileiro e Encontro Internacional sobre Dor. São Paulo: Lemos Editorial \& Gráficos Ltda. 2001, p.250.

ANZIEU, D., Os Métodos Projetivos. Rio de Janeiro: Editora Campos Ltda,1984. pp. 23-24 e 210.

ARZENO, M.E.G., Psicodiagnóstico Clínico: Novas Contribuições. Porto Alegre: Artes Médicas, 1995.

BERLINCK, M.T., Dor. São Paulo: Escuta, 1999, pp.7-75.

BERNSTEIN. J., Introducción ao TAT. In: TRINCA,W. O Desenho Livre como Estímulo de Apercepção Temática. 181p. Tese (Doutorado) - Instituto de Psicologia, Universidade de São Paulo, São Paulo, 1972.

BERTHOUD, C.M. E. Re - significando a parentalidade Desafio para toda a vida. Tese (Doutorado em Psicologia). Pontifícia Universidade Católica - PUC, São Paulo, 2000.

BLEGER, J., Temas de Psicologia. Entrevista e Grupos. São Paulo: Martins Fontes, 2001. pp.1-49.

CALIGOR, L., The Determination of the Individual's Unconscious Concept of his Masculinity-Femininity Identification. In: TRINCA, W., O Desenho Livre como Estímulo de Apercepção Temática. 181p. Tese (Doutorado) - Instituto de Psicologia, Universidade de São Paulo, São Paulo, 1972.

CARVALHO, M.M.J. (org.), Dor. Um Estudo Multidisciplinar. São Paulo: Summus,1999. pp.9-11.

CUKIERMAN, J.G.(2001). Avaliação e Tratamento Psiquiátrico do Doente com Dor Crônica. In: Simbidor. Arquivos do $5^{\circ}$. Simpósio Brasileiro e Encontro Internacional sobre Dor. São Paulo: Lemos Editorial \& Gráficos Ltda., 2001. pp.166-168.

DELOUYA, D., A Dor entre o Corpo, seu Anseio e a Concepção de seu Objeto. In: BERLINCK, M.T. (og.), Dor. São Paulo: Escuta, 1999. pp.23-33. 
ELKISCH, P., Expresion Artística Libre. In: RABIN, A.I. e Haworth, M., Técnicas Projectivas para Niños. In: TRINCA, W. O Desenho Livre como Estímulo de Apercepção Temática. 181p. Tese (Doutorado) - Instituto de Psicologia, Universidade de São Paulo, São Paulo, 1972.

FERRARI, H.; LUCHINA, I.L.; LUCHINA, N., La Interconsulta MédicoPsicológica en el Marco Hospitalario. Buenos Aires: Ediciones Nueva Visón, 1971, p.16.

FRANCK, K., Franck drawing complepion test. In: TRINCA, W. O Desenho Livre como Estímulo de Apercepção Temática. 181p. Tese (Doutorado) - Instituto de Psicologia, Universidade de São Paulo, São Paulo, 1972.

FREUD, S. (1895). Projeto para uma Psicologia Cientifica. In: Edição standart brasileira das obras psicológicas completas de Sigmund Freud. Trad. sob a direção geral de Jayme Salomão. Rio de Janeiro: Imago Editora, 1969, v. I, pp.396-469.

(1905), Tratamento Psíquico (Ou Mental). In: Edição standart brasileira das obras psicológicas completas de Sigmund Freud. Trad. sob a direção geral de Jayme Salomão. Rio de Janeiro: Imago Editora,1969, v. VII, pp.22-306.

(1914), Sobre o Narcisismo: Uma Introdução. In: Edição standart brasileira das obras psicológicas completas de Sigmund Freud. Trad. sob a direção geral de Jayme Salomão. Rio de Janeiro: Imago Editora, 1969, v. XIV, pp.92-103.

(1914), Recordar, Repetir e Elaborar (Novas Recomendações sobre a Técnica da Psicanálise II). In: Edição standart brasileira das obras psicológicas completas de Sigmund Freud. Trad. sob a direção geral de Jayme Salomão. Rio de Janeiro: Imago Editora,1969, v. XII, pp.197-198.

(1915), Os Instintos e Suas Vicissitudes. In: Edição standart brasileira das obras psicológicas completas de Sigmund Freud. Trad. sob a direção geral de Jayme Salomão. Rio de Janeiro: Imago Editora, 1969, v. XIV, p.148.

. (1915), Artigos Sobre Metapsicologia. In: Edição standart brasileira das obras completas de Sigmund Freud. Trad. sob a direção geral de Jayme Salomão. Rio de Janeiro: Imago Editora, 1969, v. XIV, pp.123-169.

(1915), O Inconsciente. In: Edição standart brasileira das obras psicológicas completas de Sigmund Freud. Trad. sob a direção geral de Jayme Salomão. Rio de Janeiro: Imago Editora, 1969, v. XIV, pp.185-224.

. (1917[1915]), Luto e Melancolia. In: Edição standart brasileira das obras psicológicas completas de Sigmund Freud. Rio de Janeiro, Imago Editora, 1969, v. XIV, pp.276-281. 
(1920), Além do Principio do Prazer. In: Edição standart brasileira das obras psicológicas completas de Sigmund Freud. Trad. sob a direção geral de Jayme Salomão. Rio de Janeiro: Imago Editora, 1969, v. XVIII, pp.45-75.

.(1923), O Ego e o Id. In: Edição standart brasileira das obras psicológicas completas de Sigmund Freud. Trad. sob a direção geral de Jayme Salomão. Rio de Janeiro, Imago Editora,1969, v. XIX, p.47.

.(1924), O Problema Econômico do Masoquismo. In: Edição standart brasileira das obras psicológicas completas de Sigmund Freud. Trad. sob a direção geral de Jayme Salomão. Rio de Janeiro: Imago Editora, 1969, v. XIX, pp.204-212.

.(1924), A Dissolução do Complexo de Édipo. In: Edição standart brasileira das obras psicológicas completas de Sigmund Freud. Trad. sob a direção geral de Jayme Salomão. Rio de Janeiro: Imago Editora, 1969, v. XIX, p.221.

.(1926[1925]), Inibições, Sintomas e Ansiedade. In: Edição standart brasileiras das obras completas de Sigmund Freud. Trad. sob a direção geral de Jayme Salomão. Rio de Janeiro: Imago Editora, 1969, v. XX, pp.195-197.

.(1930[1929]), O Mal-Estar na Civilização. In: Edição standart brasileiras das obras completas de Sigmund Freud. Trad. sob a direção geral de Jayme Salomão. Rio de Janeiro, Imago Editora, 1969, v. XXI, pp.92-141.

GARCIA-ROZA, L.A., Introdução à Metapsicologia Freudiana. Rio de Janeiro: Jorge Zahar Editor, 2000, v. 1, pp.69-153.

.(2000), Introdução à Metapsicologia Freudiana. Rio de Janeiro: Jorge Zahar Editor, v. 2, pp.24-163.

GIAMI, A., Pesquisa em Psicologia Clínica ou Pesquisa Clínica. [S.l., s.n.]. 1993.

GRANJA, E.C., Diretrizes para a Elaboração de Dissertações e Teses. São Paulo: Universidade de São Paulo. Instituto de Psicologia. Serviço de Biblioteca e Documentação, 1999.

HAKELIUS, A., Prognosis in Sciatica: A Clinical Follow-up of Surgical and non Surgical Treatment. In: AMARAL, A., Lombalgia na Síndrome PósLaminectomia. In: Simbidor. Arquivos do $5^{\circ}$. Simpósio Brasileiro e Encontro Internacional sobre Dor. São Paulo: Lemos Editorial \& Gráficos Ltda. 2001, p.250.

HAMMER, E.F., Testes Proyectivos Graficos. Buenos Aires, Editorial Paidós, 1969, pp.21-81.

JUAN-DAVID, N., O livro da Dor e do Amor. Rio de Janeiro, Jorge Zahar Editor, 1997, pp.23-169. 
KOPPITZ, E.M., Emotional Indicators on Human Figure Drawing of Boys and Girls from Lower and Midddle-Class Backgrounds. In: TRINCA, W., O Desenho Livre como Estímulo de Apercepção Temática. 181p. Tese (Doutorado) Instituto de Psicologia, Universidade de São Paulo, São Paulo, 1972.

KOVÁCS, M.J., Pacientes em Estágio Avançado da Doença. A Dor da Perda e da Morte. In: Carvalho, M.M.M.J. (org.), Dor. Um Estudo Multidisciplinar. São Paulo: Summus Editorial, 1999. p.320.

, Dor e o Paciente Oncológico. Questões psicológicas. In: Simbidor. Arquivo $5^{\circ}$. Simpósio Brasileiro e Encontro Internacional sobre Dor. São Paulo: Lemos Editorial \& Gráficos Ltda. 2001, p.184.

LEVY, S., Figure Drawing as a Projective Test. In: TRINCA, W., O Desenho Livre como Estímulo de Apercepção Temática. 181p. Tese (Doutorado) - Instituto de Psicologia, Universidade de São Paulo, São Paulo, 1972.

LORENÇÃO, V.K., Sobre a Técnica do Desenho da Figura Humana na Exploração da Personalidade. In: TRINCA, W., O Desenho Livre como Estímulo de Apercepção Temática. 181p. Tese (Doutorado) - Instituto de Psicologia, Universidade de São Paulo, São Paulo, 1972.

McDOUGALL, J., Em Defesa de Uma Certa Anormalidade: Teoria e Clínica Psicanalítica. Porto Alegre: Artes Médicas, 1989, p.158.

MACHOVER, K., Personality Projection in the Drawing of the Human Figure. In: TRINCA, W., O Desenho Livre como Estímulo de Apercepção Temática. 181p. Tese (Doutorado) - Instituto de Psicologia, Universidade de São Paulo, São Paulo, 1972.

MENNIGER, K. (1965), Eros e Thanatos. O Homem Contra Si Próprio. In: KOVÁCS, M.J., Pacientes em Estágio Avançado da Doença. A Dor da Perda e da Morte. In: Carvalho, M.M.M.J. (org.), Dor. Um Estudo Multidisciplinar. São Paulo: Summus Editorial, 1999. pp.321-322.

MEYER, L., O Método Psicanalítico. In: SILVA, M.E.L. (coord.), Investigação e Psicanálise. Campinas: Papirus, 1993, pp.27-49.

MURRAY, H. A. e col., Exploration in personality. In: ANASTASI, A. Testes psicológicos, São Paulo: Editora Pedagógica e Universitária Ltda, 1977, p.598.

NASIO, J.D., O Livro da Dor e do Amor. Rio de Janeiro: Jorge Zahar Editor, 1997. pp.17 e 31.

OGDEN, J., Health Psychology. A Textbook. In: Carvalho, M.M.M.J. (org.), Dor. Um Estudo Multidisciplinar. São Paulo: Summus Editorial, 1999, p.199. 
OCAMPO, M.L.S.(1976), Las Técnicas Proyectivas y el Proceso Psicodiagnóstico. Buenos Aires: Ediciones Nueva Visón, v. I, p.18.

PERISSINOTTI, D.M.N. (2001), Dinâmica Psicológica do Doente com Dor Muscular. In: Simbidor. Arquivos do $5^{\circ}$. Simpósio Brasileiro e Encontro Internacional sobre Dor. São Paulo: Lemos Editorial \& Gráficos Ltda, 2001, pp.181-182.

PIMENTA, C.A.M., Fundamentos Teóricos da Dor e de sua Avaliação. In CARVALHO, M.M.J. (org.), Dor. Um Estudo Multidisciplinar. São Paulo: Summus, 1999, pp.31-47.

PRUD'HOMMEAU, M., Le dessin de l'enfant. In: O Desenho Livre como Estímulo de Apercepção Temática. 181p. Tese (Doutorado) - Instituto de Psicologia, Universidade de São Paulo, São Paulo, 1972.

RETONDO, M.F.N.G., Manual prático de avaliação do H.T.P. (Casa, Árvore, Pessoa) e Família. São Paulo: Casa do Psicólogo, 2000, pp.27-116.

ROMAnO, B.W., Princípios para a Prática da Psicologia Clínica em Hospitais. São Paulo: Casa do Psicólogo, 1999, pp.25-35.

RORSCHACH, H., Psychodiagnostics: A Diagnostic Test Based on Perception. In: ANASTASI, A., Testes Psicológicos, São Paulo: Editora Pedagógica e Universitária Ltda., 1977, p.594.

SAAL, J.S. et al., High Levels of Inflammatory Phospholipase. An activity in Lumbar Disc Herniations. In: AMARAL, A., Lombalgia na Síndrome PósLaminectomia. In: Simbidor. Arquivos do $5^{\circ}$. Simpósio Brasileiro e Encontro Internacional sobre Dor. São Paulo: Lemos Editorial \& Gráficos Ltda. 2001, p.250.

SAFRA, G., O Uso de Material Clínico na Pesquisa Psicanalítica. In: SILVIA, M.E.L. (coord.), Investigação e Psicanálise. Campinas: Papirus, 1993, pp.119133.

SAUNDERS, C., Hospice and Palliative Care. An Interdisciplinary Approach. In: KOVÁCS, M.J., Pacientes em Estágio Avançado da Doença. A Dor da Perda e da Morte. In: Carvalho, M.M.M.J. (org.), Dor. Um Estudo Multidisciplinar. São Paulo: Summus Editorial, 1999, p.318.

SILVA, G.V.; TERRONI, L., Manifestações Psiquiátricas e Dor Crônica Psychiatric Conditions and Chronic Pain. In: Temas Teoria e Prática do Psiquiatra. São Paulo: 2000. v. 30 nº. 59, pp.199-211.

SONENREICH, C.; ESTEVÃO, G.; FILHO, L.M.A., Psiquiatria: Propostas, Notas e Comentários. São Paulo: Lemos Editorial, 1999. 
STERN, E., Testes de Personalidade. In: TRINCA, W., O Desenho Livre como Estímulo de Apercepção Temática. 181p. Tese (Doutorado) - Instituto de Psicologia, Universidade de São Paulo, São Paulo, 1972.

TEIXEIRA, M.J., Síndrome Dolorosas. In: Carvalho, M.M.M.J. (org.), Dor. Um Estudo Multidisciplinar. São Paulo: Summus Editorial, 1999, p.81.

TRINCA, W., O Desenho Livre como Estímulo de Apercepção Temática. 181p. Tese (Doutorado) - Instituto de Psicologia, Universidade de São Paulo, São Paulo, 1972.

Diagnóstico Psicológico a prática clínica. In: RAPPAPORT, C.R. (coord.), Temas Básicos de Psicologia. São Paulo: Editora Pedagógica e Universitária Ltda., 1984, pp. 14-24.

THURSTONE, L.L., A Factorial Study of Perception. In: ANASTASI, A., Testes Psicológicos. São Paulo: Editora Pedagógica e Universitária Ltda, 1977, pp.381-382.

WARTEGG, E., Gestalt und Charakter. In: WALTER, T., O Desenho Livre como Estímulo de Apercepção Temática. 181p. Tese (Doutorado) - Instituto de Psicologia, Universidade de São Paulo, São Paulo, 1972. 